\title{
MODIFICATIONS TO THE DIFFUSION ANALOG" SURFACE-WATER FLOW MODEL (DAFLOW) FOR COUPLING TO THE MODULAR FINITE- DIFFERENCE GROUND-WATER FLOW MODEL (MODFLOW)
}

by Harvey E. Jobson and Arlen W. Harbaugh

U.S. GEOLOGICAL SURVEY

Open-file Report 99-217 


\section{U.S. DEPARTMENT OF THE INTERIOR \\ BRUCE BABBIT, Secretary}

U.S. GEOLOGICAL SURVEY

Charles G. Groat, Director

The use of trade, product, industry, or firm names is for descriptive purposes only and does not imply endorsement by the U.S. Government.

For additional information write to:

Chief, Office of Surface Water

U.S. Geological Survey, WRD

415 National Center

Reston, VA 20192
Copies of this report can be purchased from:

U.S. Geological Survey

Federal Center

Box 25286

Denver, CO 80225-0286 


\section{TABLE OF CONTENTS}

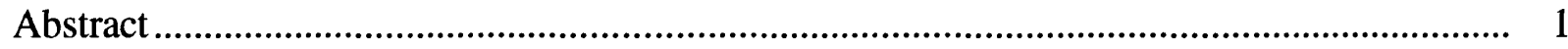

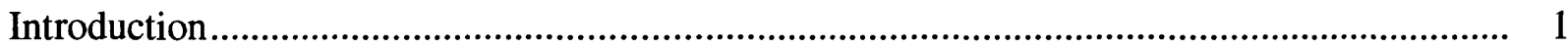

Conceptualization of Routing Streamflows .......................................................................... 2

Structure of the Modular Finite-Difference Ground-Water Flow Model and the

Diffusion Analogy Surface-Water Flow Model................................................................... 6

Numbering and Ordering of Streams .................................................................................... 7

Computing Flow Between and Stream and Aquifer .......................................................... 10

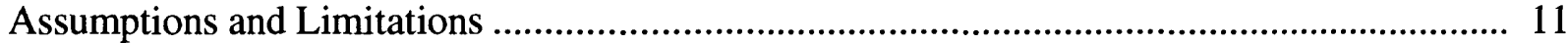

Modifications to the Diffusion Analogy Flow Model ......................................................... 12

Implementation in the Modular Finite-Difference Ground-Water Flow Model ....................... 17

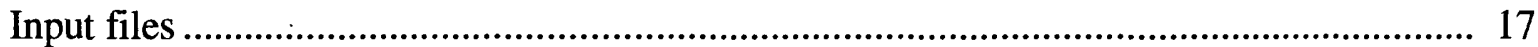

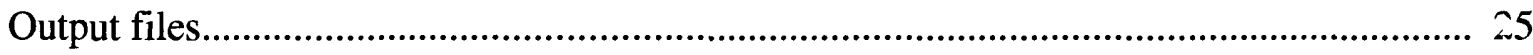

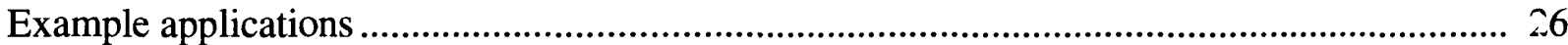

Example 1, Streamflow resulting from variable recharge, comparison with an

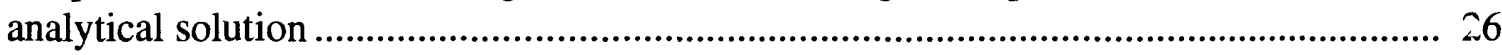

Example 2, Bank storage due to flood stages, comparison with an analytical solution ..... 36

Example 3, Bank storage under unsteady flow................................................................... 43

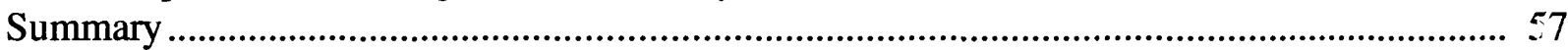

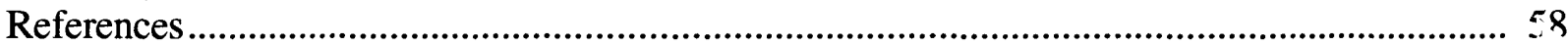

Appendix A Source Code for Diffusion Analogy Flow Model Subroutines............................ \&1

Appendix B MODFLOW data files for Example 1 simulation ................................................ 95

Appendix C MODFLOW data files for Example 2 simulation .................................................. 99

Appendix D MODFLOW data files for Example 3 simulation ....................................................102

\section{FIGURES}

1. Schematic showing steady uniform flow subreaches connected by a transition of uniformly progressive flow

2. Example schematic showing the numbering system of the linked surface-water/ ground-water model ..................................................................................................... 9

3. Diagram showing one ground-water cell with stream depicting properties used in calculation of the streambed leakage for a subreach.................................................. 10

4. Overall program structure of the Diffusion Analogy Flow model .................................... 14

5. Overall program structure of the Diffusion Aanlogy Flow model linked to the Modular Finite-Difference Ground-Water Flow model............................................... 16

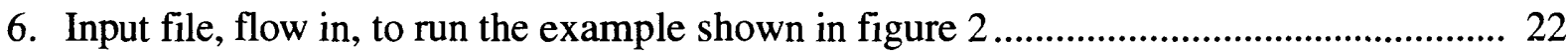

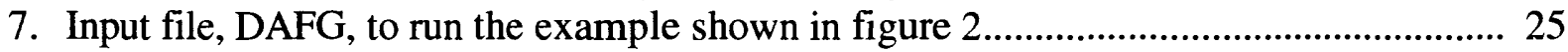

8. Sketch showing aquifer grid of example 1 with surface-water model grid superimposed

9. Graph showing the distribution of recharge used for the analytical and numerical

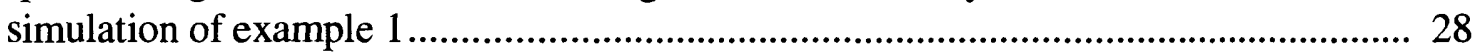

10. Input file, flow-in, for example 1 ......................................................................... 30 
11. Input file, DAFG, for example 1

12. Selected output of the Modular Finite-Difference Ground-Water Flow model results at stress period 134, for example 1 ................................................................. 32

13. Graph showing the simulated streamflow at node 14 and the analytical solution ............. 34

14. Graph showing the simulated and analytical variation of water level in a well located in row 7, column 10 of figure 8 .................................................................... 35

15. Graph showing the aquifer-head profiles simulated by the Diffusion Analogy Flow model linked to the Modular Finite-Difference Ground-Water Flow model and the analytical solution

16. Graph showing the distribution of streamflow for a 30-day flood event used in example 2 ..................................................................................................... 38

17. Input file, flow.in, for example 2 ............................................................................... 39

18. Selected output of the Modular Finite-Difference Ground-Water Flow model at

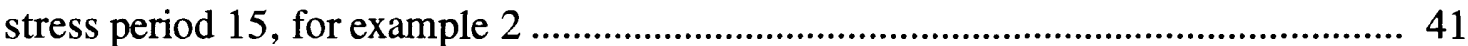

19. Comparison of simulated and analytic flow between the aquifer and the stream for example 2 ......................................................................................................... 43

20. Sketch showing ground-water model grid of example 3 with surface water model grid superimposed ................................................................................................ 45

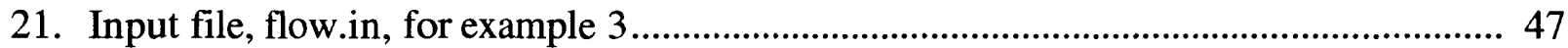

22. Input file, DAFG, for example 3 ........................................................................... 51

23. Graph showing selected output of the Modular Finite-Difference Ground-Water Flow model at end of time steps 6 and 11, for example 3 .......................................... 53

24. Graph showing flow distribution at selected points of the channel in example 3 , illustrating the bank storage effect on the flow hydrograph ......................................... 55

25. Graph showing flow into and out of the aquifer of example 3 as a function of time ........ 56

\section{TABLE}

1. Input format for the Diffusion Analogy Flow Model................................................ 18 


\section{LIST OF SYMBOLS}

\begin{tabular}{|c|c|}
\hline A & cross-sectional area of flow \\
\hline A0 & cross-sectional area at zero flow \\
\hline Al & hydraulic-geometry coefficient for area \\
\hline A2 & hydraulic-geometry exponent for area \\
\hline $\mathrm{A}_{1}, \mathrm{~A}_{2}$ & cross-sectional area downstream and upstream of wave, Respectively \\
\hline $\mathrm{B}_{\mathrm{e}}$ & elevation of streambed as it crosses the aquifer cell \\
\hline $\mathrm{B}_{1}$ & thickness of the streambed \\
\hline $\mathrm{C}$ & celerity of moving wave \\
\hline $\mathrm{D}_{1}$ & wave dispersion coefficient \\
\hline $\mathrm{D}_{\mathrm{L}}$ & diffusive length scale \\
\hline $\mathrm{g}$ & acceleration of gravity \\
\hline $\mathrm{H}_{\mathrm{d}}$ & head of aquifer in the cell \\
\hline $\mathrm{K}$ & conveyance \\
\hline $\mathrm{K}_{\mathrm{c}}$ & hydraulic conductivity of the streambed \\
\hline $\mathrm{L}$ & length of stream reach in communication with the aquifer \\
\hline $\mathrm{L}_{\mathrm{a}}$ & distance traveled by a wave during one time step \\
\hline n & Mannings resistance coefficient \\
\hline Q & discharge \\
\hline$Q_{0}$ & channel forming discharge \\
\hline$Q_{s}$ & flow under steady uniform flow conditions \\
\hline $\mathrm{Q}_{1}, \mathrm{Q}_{2}$ & discharge downstream and upstream of wave, respectively \\
\hline $\mathrm{S}_{\mathrm{ep}}$ & flow from the aquifer to the stream as seepage \\
\hline $\mathrm{S}_{\mathrm{f}}$ & friction slope in channel flow \\
\hline $\mathrm{S}_{\mathrm{o}}$ & slope of channel bed \\
\hline $\mathrm{T}$ & time \\
\hline $\mathrm{U}$ & velocity \\
\hline W & top width of channel \\
\hline W 1 & hydraulic-geometry coefficient for width \\
\hline W2 & hydraulic-geometry exponent for width \\
\hline $\mathbf{x}$ & distance coordinate, north to south, for MODFLOW \\
\hline $\mathrm{X}$ & distance coordinate, along the channel \\
\hline $\mathrm{y}$ & distance coordinate, west to east, for MODFLOW \\
\hline Y & depth of flow \\
\hline $\mathbf{z}$ & vertical distance coordinate, for MODFLOW \\
\hline$\Delta \mathrm{t}$ & time increment \\
\hline$\Delta \mathrm{x}$ & incremental distance along $\mathrm{x}$ coordinate \\
\hline
\end{tabular}


CONVERSION FACTORS

\begin{tabular}{rll}
\hline Multiply & By & To obtain \\
inch (in.) & 25.4 & millimeter $(\mathrm{mm})$ \\
foot $(\mathrm{ft})$ & 0.3048 & meter $(\mathrm{m})$ \\
foot/second $(\mathrm{ft} / \mathrm{s})$ & 0.3048 & meter/second $(\mathrm{m} / \mathrm{s})$ \\
mile $(\mathrm{mi})$ & 1.609 & kilometer $(\mathrm{km})$ \\
square foot $\left(\mathrm{ft}^{2}\right)$ & 0.09290 & square meter $\left(\mathrm{m}^{2}\right)$ \\
square mile $\left(\mathrm{mi}^{2}\right)$ & 2.590 & square kilometer $\left(\mathrm{km}^{2}\right)$ \\
cubic foot $\left(\mathrm{ft}^{3}\right)$ & 0.02832 & cubic meter $\left(\mathrm{m}^{3}\right)$ \\
cubic foot per second $\left(\mathrm{ft}^{3} / \mathrm{s}\right)$ & 0.02832 & cubic meter per second $\left(\mathrm{m}^{3} / \mathrm{s}\right)$
\end{tabular}

\section{ADDITIONAL ABBREVIATIONS}

cal calorie

\section{ACRONYMS}

$\begin{aligned} \text { DAFLOW } & \text { Diffusion Analogy Flow Model } \\ \text { FTP } & \text { File Transfer Protocol } \\ \text { GW } & \text { Ground water } \\ \text { MODFLOW } & \text { Modular Finite Difference Ground-Water Flow Model } \\ \text { SW } & \text { Surface Water }\end{aligned}$




\title{
Modifications to the Diffusion Analogy Surface-Water Flow Model (DAFLOW) for Coupling to the Modular Finite- Difference Ground-Water Flow Model (MODFLOW)
}

\author{
by Harvey E. Jobson and Arlen W. Harbaugh
}

\section{Abstract}

Surface-water and ground-water computer models are widely used to simulate flow for evaluating and managing water resources. Simulation of the surface-water/ground-water interaction is, however, less well developed. To facilitate the simulation of this interaction, tho surface-water flow model (DAFLOW) has been coupled to the modular, finite-difference, ground-water flow model (MODFLOW).

The DAFLOW model routes flows through a system of inter-connected one-dimensional channels and subdivides the system into a series of branches, with each branch divided into a number of subreaches. MODFLOW simulates ground-water flow through a three-dimensional grid of cells. The models are coupled by adding an exchange between each subreach and a specified ground-water cell, with the amount of flow from the stream to ground water being limited to the available streamflow. The water exchange for each subreach is computed on the basis of the stream-aquifer head difference, the streambed thickness, stream width, and streambed hydraulic conductivity.

Three example applications are provided to assess the accuracy of the solutions and demonstrate the use of the combined models.

\section{INTRODUCTION}

Computer models that simulate ground-water (GW) and surface-water (SW) flow are widely used to evaluate and manage ground- and surface-water resources. The MODFLOW model (Harbaugh and McDonald, 1996; McDonald and Harbaugh, 1988) simulates three-dimensional GW flow and includes the effects of many steady-state or transient processes, such as areal recharge, rivers, drains, evapotranspiration, and pumpage. The DAFLOW model, Jobson (1989) simulates one-dimensional flow through a system of interconnected channels by solving the diffusive-wave form of the flow equations. DAFLOW subdivides the stream system into a se-ies of branches, with each branch divided into a number of subreaches. It is designed to simulate flow in upland stream systems where flow reversals do not occur and backwater conditions are not severe. If these two conditions are satisfied, DAFLOW can be applied with reasonable accuracy using minimal field data.

This report describes the coupling of MODFLOW and DAFLOW. Although other methods of simulating surface-water interaction have been previously incorporated within MODFLOV $r$ (McDonald and Harbaugh, 1988; Prudic, 1989; and Swain and Wexler, 1993), DAFLOW provides a highly stable solution scheme that is simple to run and requires a minimum of field data and calibration. This report does not, however, attempt to compare the different approaches, 
so potential users of the coupled MODFLOW and DAFLOW models should also evaluate these other approaches in order to choose the best approach for their particular problem.

To facilitate coupling the models, the DAFLOW code was separated into subroutines that are consistent with the modular structure of MODFLOW. These subroutines were structured such that multiple DAFLOW time steps can be run iteratively within a MODFLOW time step.

DAFLOW was also modified to allow subreaches to go dry so that it will be possible to simulate streams from which the entire flow seeps into the ground.

MODFLOW is divided into a main program and a series of independent sets of subroutines called packages, which allows additional capabilities to be easily incorporated. To couple DAFLOW to MODFLOW, a group of subroutines was written that incorporates DAFLOW as a MODFLOW package. These additional subroutines calculate the water exchange between the SW and GW systems.

This report: (1) gives a brief conceptualization of routing streamflow and a summary of the theory of the DAFLOW model, (2) describes the mechanics of computing the leakage to the aquifer, (3) documents the modifications to the DAFLOW model needed for it to be couplet to the MODFLOW package, (4) describes the calls necessary to couple MODFLOW and DAFLOW, (5) describes the input files necessary to run DAFLOW with MODFLOW, as well as the output files, and (6) presents three example applications.

All U.S. Geological Survey (USGS) hydrologic analysis software is available for electronic retrieval by means of either the World Wide Web (WWW) at http://water.usgs.gov/software or by anonymous File Transfer Protocol (FTP) from water.usgs.gov in pub/software/surface_water directory.

\section{CONCEPTUALIZATION OF ROUTING STREAMFLOWS}

The differential equations derived by Saint-Venant (1871) for one-dimensional, unsteady flow are the basis for the diffusion analogy method used by DAFLOW. Assuming no lateral inflow, the Saint-Venant equations for channel flow are the continuity of mass equation:

$$
\frac{\partial Q}{\partial x}+\frac{\partial A}{\partial t}=0
$$

and the continuity of momentum equation:

$$
\frac{1}{\mathrm{~g}} \frac{\partial \mathrm{U}}{\partial \mathrm{t}}+\frac{\mathrm{U} \partial \mathrm{U}}{\mathrm{g} \partial \mathrm{X}}+\frac{\partial \mathrm{Y}}{\partial \mathrm{X}}+\mathrm{S}_{\mathrm{f}}-\mathrm{S}_{\mathrm{O}}=0
$$

in which $\mathrm{Q}$ is discharge, $\mathrm{X}$ is distance along the channel, $\mathrm{A}$ is the cross-sectional area of flow, $t$ is time, $g$ is the acceleration of gravity, $U$ is velocity, $Y$ is depth, $S_{f}$ is the friction slope, and $S_{o}$ is the streambed slope.

DAFLOW approximates the flow distribution in a stream as reaches of steady uniform flow separated by transitions of unsteady flow as illustrated in figure 1. The transitions are considered to be regions of uniformly progressive flow, as defined by Chow (1959, p 528). This type of flow has a stable wave profile that does not change shape as it moves down the channel. One common type of uniformly progressive flow, which approximates most flood waves in natural channels, is the monoclinal rising wave (Chow, 1959, p 528). Kleitz (1877) developed the mathematical principle of uniformly progressive waves, but it was Seddon (1900) and Wilkinson (1945) who 
showed it to be applicable to actual rivers. Wilkinson found that the mid-point of the rise or fall in stages were best suited for determining the velocity of an observed wave.

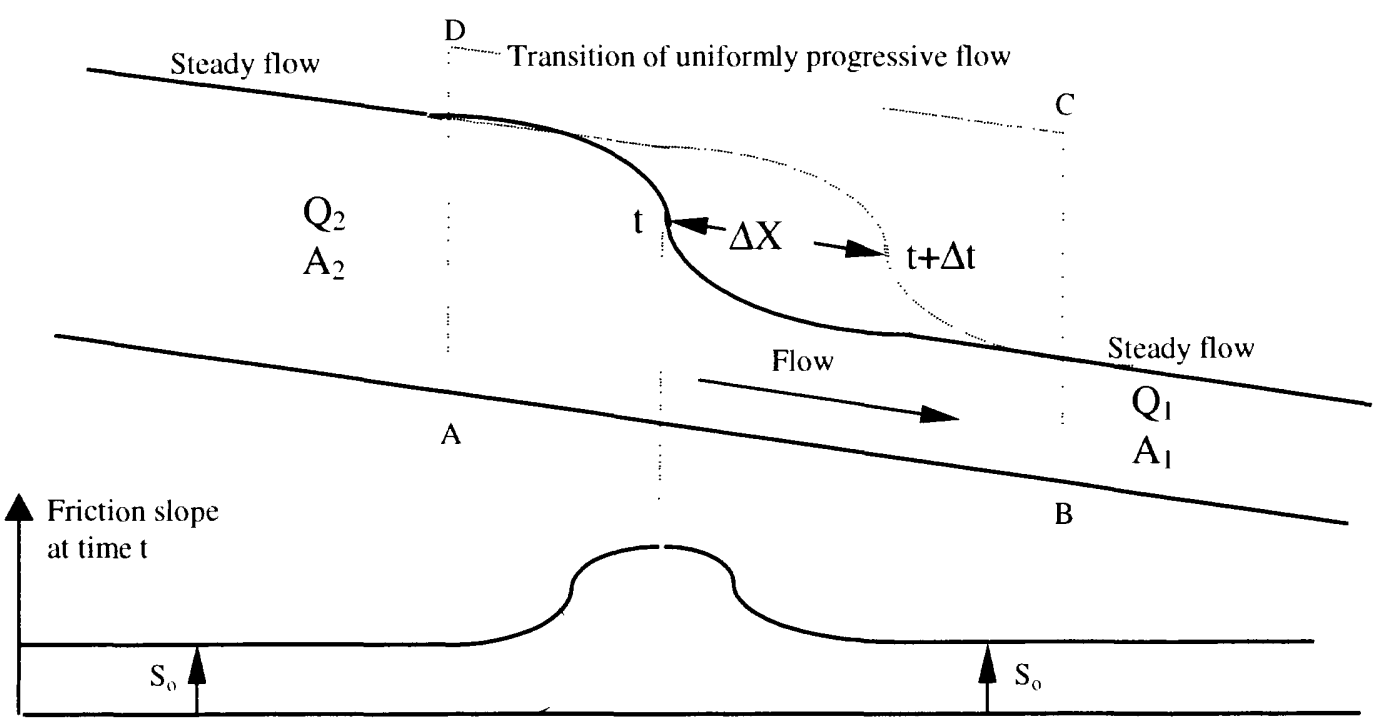

Figure 1. Schematic showing steady uniform flow subreaches connected by a transition of uniformly progressive flow.

By considering the flow into and out of the control volume $\mathrm{ABCD}$ (figure 1), it is shown that:

$$
\mathrm{Q}_{2} \Delta \mathrm{t}-\mathrm{Q}_{1} \Delta \mathrm{t}=\left(\mathrm{A}_{2}-\mathrm{A}_{1}\right) \Delta \mathrm{x}
$$

or

$$
\mathrm{C}=\frac{\Delta \mathrm{X}}{\Delta \mathrm{t}}=\frac{\mathrm{Q}_{2}-\mathrm{Q}_{1}}{\mathrm{~A}_{2}-\mathrm{A}_{1}} \Rightarrow \frac{\partial \mathrm{Q}}{\partial \mathrm{A}}
$$

in which $C$ is the speed of the moving wave, or celerity, $Q_{1}$ and $Q_{2}$ are the discharge downstream and upstream of the wave, respectively, and $A_{1}$ and $A_{2}$ are the cross-sectional areas downstream and upstream of the wave, respectively.

For the unsteady portion of the flow (the transition) it can be seen that the rate of change cf depth with distance has a maximum absolute value at the inflection point and approaches zerc both upstream and downstream of the wave. The shape of the curve representing the rate of change of depth with distance in the transition can often be approximated as a Normal probability density function.

Ignoring the first two terms (the acceleration terms) of the momentum equation (2) the friction slope can be approximated as:

$$
S_{f}=S_{o}-\frac{\partial Y}{\partial X}=S_{o}-\frac{1}{W} \frac{\partial A}{\partial X}
$$

in which $\mathrm{W}$ is the top width of the channel. The last form of the equation is strictly valid only for a prismatic channel. The friction slope is equal to the streambed slope in each steady flow rea:h and is a maximum at the inflection point as illustrated on figure 1 . 
The friction slope is often estimated by using an empirical equation of the type:

$$
S_{f}=\frac{Q^{2}}{K^{2}},
$$

in which $\mathrm{K}$ is the conveyance, which is often computed from an equation of the Manning type:

$$
K=\frac{1.49}{n} \frac{A^{5 / 3}}{2 / 3},
$$

in which $\mathrm{n}$ is the Manning roughness coefficient and $\mathrm{W}$, the top width, has been substituted for the more correct wetted perimeter. Equation 6 is expressed in the English system of units; in metric units the constant 1.49 is replaced with 1.0. Equation 5 is often expressed in terms of the streambed slope $\left(S_{0}\right)$ rather than $S_{f}$ in which case the computed discharge is considered to $l \cdot 0$ the flow that would occur under steady uniform conditions $\left(Q_{s}\right)$. Substituting equation 5 into equation 4:

$$
\frac{\mathrm{Q}^{2}}{\mathrm{~K}^{2}}=\frac{\mathrm{Q}_{\mathrm{s}}^{2}}{\mathrm{~K}^{2}}-\frac{1}{\mathrm{~W}} \frac{\partial \mathrm{A}}{\partial \mathrm{X}}
$$

Multiplying both sides by $\mathrm{K}^{2}$ and completing the squares by adding $\left(\mathrm{K}^{2} / 2 \mathrm{WQ}_{s} \partial \mathrm{A} / \partial \mathrm{x}\right)^{2}$ to each side:

$$
\mathrm{Q}^{2}+\left(\frac{\mathrm{K}^{2}}{2 \mathrm{WQ}_{\mathrm{s}}} \frac{\partial \mathrm{A}}{\partial \mathrm{X}}\right)^{2}=\mathrm{Q}_{\mathrm{s}}^{2}-2 \mathrm{Q}_{\mathrm{s}} \frac{\mathrm{K}^{2}}{2 \mathrm{WQ}_{\mathrm{s}}} \frac{\partial \mathrm{A}}{\partial \mathrm{X}}+\left(\frac{\mathrm{K}^{2}}{2 \mathrm{WQ}_{\mathrm{s}}} \frac{\partial \mathrm{A}}{\partial \mathrm{X}}\right)^{2} .
$$

Solving for discharge $(\mathrm{Q})$ and ignoring the second term on the left side, because it involves the square of a derivative, an equation for the unsteady discharge in the transition region is obtained, which is based on the diffusive wave form of the momentum equation:

$$
Q=Q_{S}-\frac{K^{2}}{2 W Q_{S}} \frac{\partial A}{\partial x}=Q_{S}-D_{f} \frac{\partial A}{\partial x},
$$

in which $\mathrm{D}_{\mathrm{f}}$ is a wave-diffusion coefficient defined as:

$$
\mathrm{D}_{\mathrm{f}}=\frac{\mathrm{K}^{2}}{2 \mathrm{WQ}_{\mathrm{s}}}=\frac{\mathrm{Q}}{2 \mathrm{WS}_{\mathrm{o}}} \text {. }
$$

The second form of equation 8 is obtained by approximating $\mathrm{K}^{2}$ as $\mathrm{Q}^{\cdot} \mathrm{Q}_{\mathrm{s}} / \mathrm{S}_{\mathrm{o}}$.

As shown by Jobson $(1989$, p. 6$)$ equation 7 can be substituted into the continuity equation (1) to produce the diffusive wave form of the flow equation:

$$
\frac{\partial Q_{S}}{\partial t}+C \frac{\partial Q_{S}}{\partial x}-D_{f} \frac{\partial^{2} Q_{S}}{\partial x^{2}}=0 .
$$

The actual solution procedure used by DAFLOW is as follows. At the beginning of each time step the flow along the stream is represented as a series of steady uniform flow reaches, called waves, separated by shocks that are transition zones of zero length. During a time step, there shocks would naturally diffuse according to equation 9 , so at the end of the time step they should look similar to that shown on figure 1 . The diffusive length scale $\left(\mathrm{D}_{\mathrm{L}}\right)($ Carslaw and Jaeger, 1959),

$$
D_{\mathrm{L}}=\sqrt{2 \mathrm{D}_{\mathrm{f}} \Delta \mathrm{t}},
$$


is a measure of the distance that the shocks diffuse during the time step. At the beginning of each time step each shock is replaced by two shocks that are a distance of $2 \mathrm{D}_{\mathrm{L}}$ apart. This maintains a series of steady flow subreaches separated by shocks, and accounts for the diffusion of the waves. The discharge in the wave between the two new shocks is computed such that the volume of water in the wave is identical to what existed in the space before the mass was redistributed, by adding the shock. Within the wave, where steady uniform conditions exist, there is a unique relation between the flow area and discharge.

If the diffusion of mass around the shock obeys equation 9 with a constant value of $\mathrm{D}_{\mathrm{f}}$, the variation of water mass with distance from the shock follows a Normal probability distribution function. It can be easily shown that the mean and variance of the water-mass distribution after splitting a single shock into two shocks connected by a steady flow wave is identical to that of the Normal probability distribution, if the shocks are a distance of $2 \mathrm{D}_{\mathrm{L}}$ apart. Jobson (1989) further shows that the theoretical distribution of mass described by equation 9 can be closely approximated by repetitively breaking a single shock into two shocks a distance of $2 \mathrm{D}_{\mathrm{L}}$ apart. Once the mass of water is redistributed to account for the diffusion, the shocks are moved to new locations by computing their wave speeds from equation 3 .

The accuracy of the diffusive-wave form of the flow equation, therefore of DAFLOW, depends on the relative size of the advection and diffusion terms. The model accuracy degrades as the wave diffusion increases relative to advection. As can be seen from equation 8 , the wavediffusion coefficient is inversely proportional to the stream slope, so the model accuracy decreases as the slope decreases. One measure of the importance of the advection and diffusion terms is the ratio of the distance traveled by a wave during a time step $\left(\mathrm{L}_{\mathrm{a}}\right)$ to the diffusive length scale $\left(D_{L}\right)$. It has been found empirically that DAFLOW gives good results as long as:

$$
\frac{L_{a}}{D_{L}} \geq 0.87 \text {. }
$$

Much geomorphic information indicates that, in an average sense, the cross-sectional area of natural channels can be approximated by an equation of the form:

$$
\mathrm{A}=\mathrm{A} 0+\mathrm{A} 1 \bullet \mathrm{Q}_{\mathrm{S}}^{\mathrm{A} 2},
$$

in which A1 and A2 are constants called the hydraulic-geometry coefficient and exponent for area, respectively, and $\mathrm{A} 0$ is the average cross-sectional area at zero flow. Theoretically the value of A2 can range from 0 to 1, but its value is usually found to be between 0.5 and 0.8 with an average of 0.66 (Leopold and Maddock, 1953; Stall and Yang, 1970; Boning, 1974; Boyle and Spahr, 1985; Jobson 1989). Likewise, the width can be approximated by an equation of the form:

$$
\mathrm{W}=\mathrm{W} 1 \cdot \mathrm{Q}_{\mathrm{S}}^{\mathrm{W} 2},
$$

in which W1 and W2 are constants called the hydraulic-geometry coefficient and exponent for width, respectively. The value of W2 is generally found to range from 0.1 to 0.4 with a typical value of 0.26 (Leopold and Miller, 1956; Stall and Yang, 1970; Jobson, 1989). Hydraulicgeometry exponents have been found to maintain relatively consistent values both at a site on a stream and between streams, (Jobson 1989, Beven \& Kirkby 1993, page 91). 
Differentiating equation 11 and inverting, it is easily seen that the wave speed is determined as:

$$
C=\frac{Q_{S}^{(1-A 2)}}{A 1 \cdot A 2} .
$$

Likewise the diffusive length scale can be determined by combining equations 8,10 and 12 as:

$$
D_{L}=\frac{Q_{S}^{(1-W 2) / 2} \cdot \sqrt{\Delta t}}{\sqrt{S_{O} \cdot W 1}} \text {. }
$$

So the ratio $\mathrm{L}_{\mathrm{a}} / \mathrm{D}_{\mathrm{L}}$ can be determined as:

$$
\frac{\mathrm{L}_{\mathrm{a}}}{\mathrm{D}_{\mathrm{L}}}=\frac{\sqrt{\mathrm{S}_{\mathrm{O}} \cdot \mathrm{W} 1} \cdot \mathrm{Q}_{\mathrm{S}}^{(0.5-\mathrm{A} 2+\mathrm{W} 2 / 2)} \cdot \sqrt{\Delta t}}{\mathrm{~A} 1 \cdot \mathrm{A} 2} .
$$

The accuracy of DAFLOW depends on the time-step size and streambed slope. Streams with smaller slopes can be reasonably simulated using a larger time step. In other words, DAFLOW may provide reasonable estimates of daily flows for a low gradient stream, such as the lower reaches of the Mississippi, even though it can not resolve the small scale variations, such as might occur on a 5-minute time scale. Recall that typical values of A2 and W2 are 0.66 and 0.26 , respectively, so the exponent on $\mathrm{Q}_{\mathrm{s}}$ is typically small and discharge generally has little influence on the accuracy of the model. As a rule of thumb, the following table gives the approximate minimum slope that should be simulated by DAFLOW for various time steps.

\begin{tabular}{cc} 
Time step & Minimum Slope \\
\hline 5 minute & $10 \mathrm{ft} / \mathrm{mile} ; 0.002$ \\
1 hour & $1.5 \mathrm{ft} / \mathrm{mile} ; 0.0003$ \\
6 hour & $0.25 \mathrm{ft} / \mathrm{mile} ; 0.00005$ \\
12 hour & $0.1 \mathrm{ft} / \mathrm{mile} ; 0.00002$
\end{tabular}

\section{STRUCTURE OF THE MODULAR FINITE-DIFFERENCE GROUND-WATER FLOW MODEL AND THE DIFFUSION ANALOGY SURFACE-WATER FLOW MODEL}

MODFLOW solves the three-dimensional ground-water flow equation using finite-difference approximations (McDonald and Harbaugh, 1988, p 2-35). The finite difference procedure requires that the aquifer be divided into blocks called cells, which have dimensions $\mathrm{x}, \mathrm{y}$, and $\mathrm{z}$. The aquifer properties in each cell are assumed uniform. The head in each cell is calculatec at a point, or node, at the center of the cell. The head is calculated by iterating through the finitedifference equations for all nodes until the maximum head change in any cell between the previous and current iteration is less than a value specified by the user. Once this criterion is met, the program advances to a new time step and the process is repeated. Because the response time of surface-water systems are generally much smaller than those of ground-water systems, $t^{\circ}$. appropriate time step of a SW model is likely smaller than the appropriate time step of the GW model. 
DAFLOW was, therefore, structured so that multiple DAFLOW time steps can occur within a MODFLOW time step. During each iteration of a MODFLOW time step, a subroutine is called to calculate seepage to or from the stream. DAFLOW must also be run to route the SW flow for the MODFLOW time step. For the seepage calculations, ground-water head can either be assumed to remain constant during the GW time step, or be approximated by straight-line interpolation between the head at the beginning and end of the GW time step. The heads are assumed to remain constant during a single SW time step. The SW flow conditions at the beginning of the GW time step are stored so that the iterative process can be repeated.

\section{NUMBERING AND ORDERING OF STREAMS}

Streams superimposed on the aquifer are divided into branches and subreaches as defined in the DAFLOW documentation (Jobson, 1989) and shown on figure 2. Each branch begins and ends at a junction and junctions are numbered, starting with the interior junctions (those connecting two or more branches). Any number of branches can start or end at a junction. Each branch is divided into subreaches by node points or cross sections. Subreach 1 of branch 1 , fcexample, is the stream reach extending from node 1 to node 2 (figure 2). Each branch must have at least one subreach defined by two nodes, one at each end. The example shown in figure 2 contains three branches with one internal junction, number 1 . Branch 1 delivers water from junction 2 to junction 1 and is divided into 8 subreaches by 9 nodes. The nodes must be numbered sequentially, starting at the upstream end of the channel. The locations of the nodes are input as the distance downstream from a reference point, in miles or kilometers. The location of node 1 does not have to be zero, but negative river miles are not allowed. The locations of notes must increase with increasing node number and should be separated by at least 0.0002 units (mile or kilometer). Multiple node points at the same location are not allowed.

Flow additions, or extractions, are allowed at any interior node (for example, if a branch contains 9 nodes, flow can be exchanged at nodes 2 through 8 ). The flow exchange is assumed to occur just upstream of the node.

When MODFLOW is coupled to DAFLOW, the user specifies the MODFLOW cell to which the ground-water seepage is connected for each interior SW subreach. This means that as a minimum, a node should be placed at every point where the stream intersects a cell boundary. This will divide the stream into subreaches that are each contained within a single cell. Grourdwater seepage for the downstream node of the subreach should be assigned to the cell that contains the subreach. As shown in figure 2, most of the nodes were selected using this approach. For example, nodes 2 and 3 of branch 1 define a subreach within the cell at row 1 , column 2 . The seepage for node 3 , subreach 2 , would accordingly be assigned to the cell at row 1 , column 2 . Technically the water enters the aquifer at the center of the cell, the GW node, but it leaves the stream at the downstream edge of the cell. Additional nodes can be used if needed to define changes in hydraulic conditions or inflow points, for example, see node 4 , branch 3 . In this example, the seepage for both nodes 4 and 5 would be assigned to the same MODFLOW cell: row 4 , column 4.

As shown in figure 2, node 4 in branch 3 is needed because there is an additional inflow at this point. It might also define a point of significant change in the hydraulic characteristics of the stream, such as slope, width or depth. DAFLOW allows flow additions or extractions, in addition to ground-water seepage, at each interior node. An example diversion is shown for branch 2, 
node 4. The flow additions and subtractions are assumed not to interact with the ground water until they enter the stream. If ground-water interaction is desired, an additional branch representing the diversion or inflow would be needed.

Notice that the surface-water system can extend beyond the aquifer, e.g. branch 2, subreach 1 or branch 3, subreach 7. Subreaches that are outside of the aquifer have no interaction with the ground-water system.

Because DAFLOW does not allow flow exchanges at the last node in a branch, ground-water seepage is not allowed for the last subreach in any branch. This limitation can be minimized, for example at the ends of branches 1 and 2 in figure 2, by placing the next to the last node a very short distance upstream from the last node (however nodes must be separated by at least 0.0002 miles). In branch 3 the limitation was removed by adding a node downstream of the boundary of the GW model.

There is never any ground-water seepage represented at the first node of a branch because the ground-water seepage for a subreach is associated with the downstream node for that subreach. Thus, the seepage for subreach 1 occurs at the cell that is connected to node 2. 


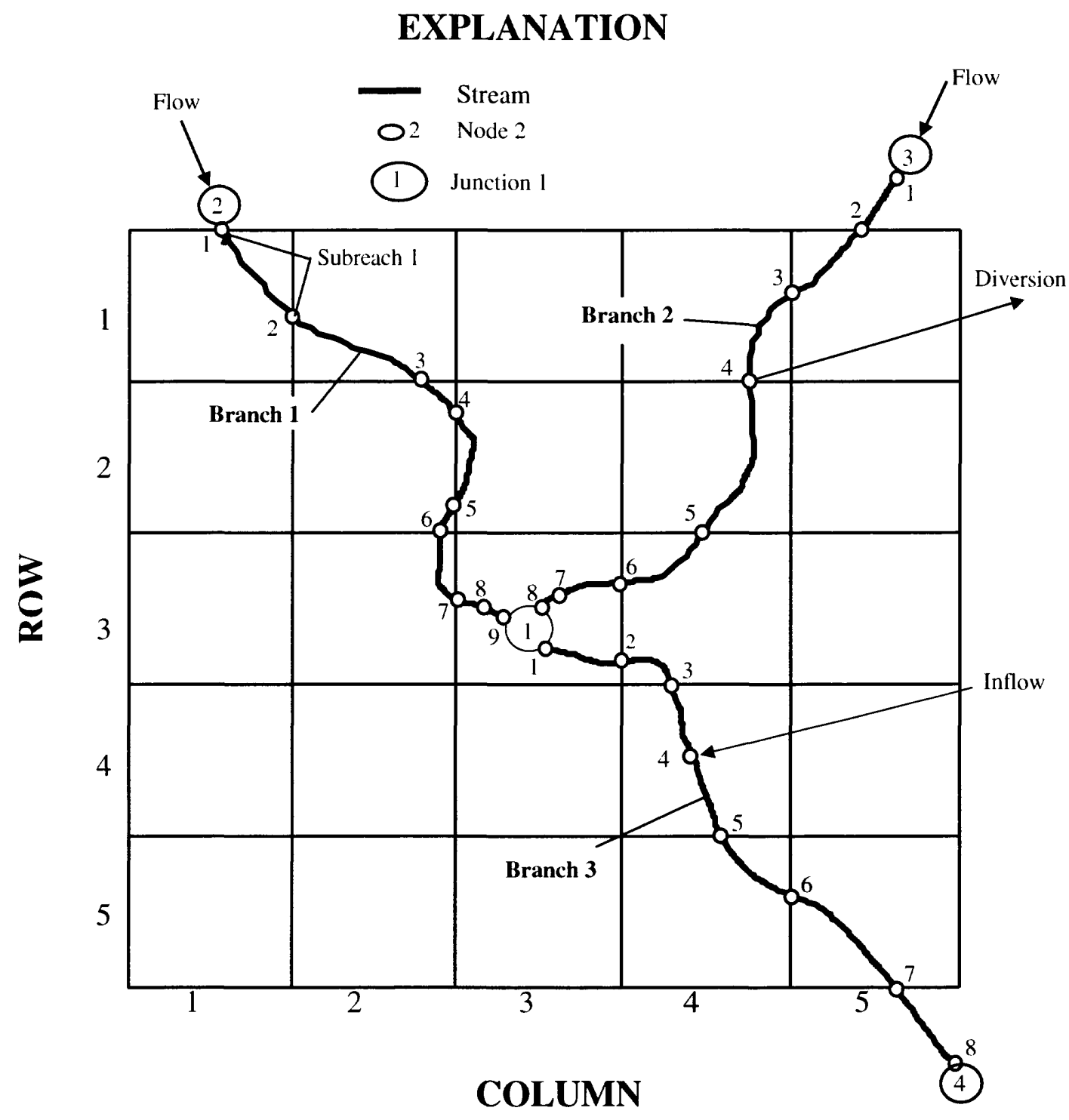

Figure 2. Example schematic showing the numbering system of the linked surface-n'ater and ground-water model. 


\section{COMPUTING FLOW BETWEEN THE STREAM AND AQUIFER}

Leakage to or from a stream subreach is computed using Darcy's law as follows:

$$
\mathrm{S}_{\mathrm{ep}}=\mathrm{K}_{\mathrm{c}} \mathrm{LW}\left(\mathrm{H}_{\mathrm{d}}-\mathrm{Y}-\mathrm{B}_{\mathrm{e}}\right) / \mathrm{B}_{\mathrm{t}},
$$

in which $S_{e p}=$ flow from the aquifer to the stream through the streambed, $\left(L^{3} / T\right) ; K_{c}=$ hydaulic conductivity of the streambed, $(\mathrm{L} / \mathrm{T}) ; \mathrm{L}=$ length of stream reach in hydraulic connection with the aquifer cell, (L); W = average width of stream along the aquifer cell, (L); $\mathrm{H}_{\mathrm{d}}=$ head of aquifer in the cell, $(L) ; Y=$ average depth of stream in subreach crossing the aquifer cell, $(L) ; B_{e}=$ average elevation of streambed as it crosses the aquifer cell, $(\mathrm{L})$; and $\mathrm{B}_{\mathrm{t}}=$ thickness of the streambe $\mathrm{f}$. A sketch of the properties used in the calculation of stream leakage to or from the aquifer is shown in figure 3.

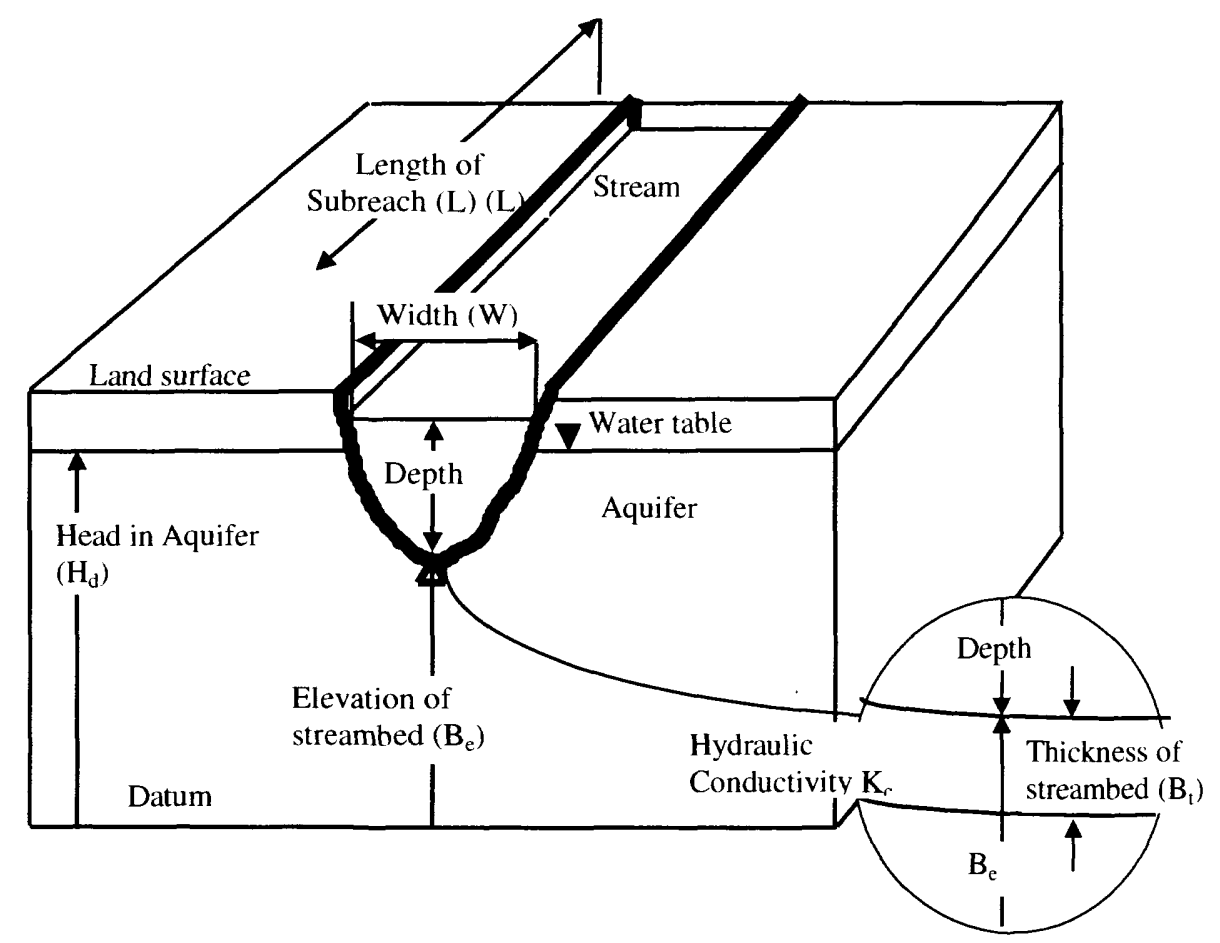

Figure 3. Diagram showing one ground-water cell with stream depicting properties used in calculation of the streambed leakage for a subreach.

The rate of flow between the aquifer and stream is computed for each SW time step. T-e first step is to compute the cross-sectional area, top width, and depth in the channel. The average cross-sectional area is computed as the volume of water divided by the subreach length. A characteristic discharge is then computed from equation 11. Finally, the stream depth is computed as the cross-sectional area divided by the top width computed from equation 12 .

The seepage flow $\left(S_{\mathrm{ep}}\right)$ is then computed by use of equation 16 . The bed elevation, $\mathrm{B}_{\mathrm{e}}$, is input for each internal node but is not used by DAFLOW for any purpose except in solving equation 16. It is not necessary, therefore, for the bed elevations to be consistent with the red slope, which is also input to the model. The bed elevation input for a node should represent the 
average bed elevation of the subreach upstream of the node, or the bed elevation near the center of the GW cell associated with the node.

Either backward or central differencing can be used in the MODFLOW model. If backward differencing is selected, the ground-water head $\left(\mathrm{H}_{\mathrm{d}}\right)$ is constant for all SW time steps within a single GW time step and is equal to the value computed at the end of the GW time step. If certral differencing is selected, the GW head is computed for each SW time step by linear interpolation with time between the values of $H_{d}$ at the beginning and end of the $G W$ time step. The seepago volume during each $\mathrm{SW}$ time step is summed during the GW time step to compute the total exchange with the aquifer.

If seepage is from the channel to the aquifer ( $S_{\text {ep }}$ is negative) the magnitude of the seepage. during any SW time step is limited to the total flow in the channel subreach plus any positive tributary inflow. If both surface-water extraction and negative seepage (flow from the stream to the aquifer) are occurring at a node and if there is not enough flow in the stream to satisfy both demands, the SW extraction is reduced first. If the seepage demands exceed the streamflow, the flow in the stream is set to zero and the seepage term is set equal to the available water in the stream.

\section{ASSUMPTIONS AND LIMITATIONS}

The DAFLOW model can simulate the flow in a network of interconnected one-dimensional channels with unsteady, unidirectional flow. The model should be applied only to channels that are characterized by one-dimensional, un-stratified flow, with fixed-channel geometry, and little backwater. The discharge at all upstream boundary points (upstream ends of external branches and tributary inflows) must be specified as a function of time. When more than one branch originates at a junction, a constant percentage of the flow at the junction must enter each branch and the percentage must be specified. Because backwater conditions are not simulated, no downstream boundary conditions are required.

DAFLOW uses a simplification of the dynamic wave equations, and therefore, it should b: used with caution. Model accuracy increases with increasing slope. The accuracy is excellent for upland streams where generally there is a unique relation between stage and discharge.

The model allows no diffusion (backwater) through junctions so the peak-flow attenuation is somewhat limited if numerous junctions occur. Tributaries allow flow exchange without affecting backwater or peak-flow attenuation and add little complexity to the system, so they should be used wherever possible in place of a branch. However, it is desirable to treat the tributary as a branch rather than just a point addition if a significant time lag and (or) flow attenuation is expected to occur in the tributary.

The restriction that each stream subreach can interact with a single cell in the ground-water flow model results in some limitations on cell size compared to the dimensions of the stream. First, the maximum width of a subreach should be no wider than a finite-difference cell. The model will still operate if this assumption is violated, but some accuracy will be lost because the ground-water seepage will occur in a single cell when it should be divided among all the cells covered by the width of the subreach. Similarly for the vertical direction, the channel depth for a subreach should not cross through more than one model layer. Again, the model will operate if this assumption is violated, but the ground-water seepage will be represented in only a single layer. 
When the MODFLOW cell is much wider than the width of a stream, the ground-water model may not represent the ground-water head near the stream very accurately. This is be ause the head distribution near a stream that has significant ground-water interaction can be complex. The more complex the head distribution is in an area, the more cells are required to represent that distribution accurately. If there is an inadequate number of cells to represent the stream-affected head distribution, then the seepage will not be accurately simulated.

\section{MODIFICATIONS TO THE DIFFUSION ANALOGY FLOW MODEL}

A number of modifications have been made to DAFLOW since it was first published in 1989. These modifications will be discussed first and then the modifications that were made so tlat it can be linked with MODFLOW will be outlined.

When DAFLOW was first published, the user input a constant wave-diffusion coefficient $\left(D_{f}\right)$ for each subreach even though, as can be seen from equation 8, the wave-diffusion coefficient should vary with discharge, width, and slope. The code was later modified such that the user supplies the slope for each subreach and the model computes a wave-diffusion coefficient from equation 8 . The slope replaced the wave-diffusion coefficient in the input stream of the file, flow.in. This modification allows the model to better simulate the wave attenuation under conditions of highly variable flow and has the added advantage of using input variables that are more readily available.

The diffusion step, in subroutine ROUTE, was modified to allow reaches of zero flow, interspersed with reaches with non-zero flow. In the previous version of DAFLOW, the channel could start as a dry channel, but once flow was established, the code would not allow the flow to return completely to zero. This limitation has been removed.

In order to make the DAFLOW model easily implemented in the MODFLOW program the coding was re-organized into subroutines that perform functions consistent with the major components of MODFLOW. The DAFLOW code was grouped into a shell program and eight subroutines called by the shell program, (see figure 4).

The input file, flow.in, used by DAFLOW contains three types of information: general, branch, and boundary. The general and branch information is read by subroutine STARTDAF that also writes these data to the output file so that the user can verify that the information is correctly read by the program. STARTDAF also makes preliminary calculations, such as computing the unit conversion factors, setting the initial number of waves in the system, ard initializing the arrays containing the wave information, wave flow, and the location of each shock. The initial volume of water in each subreach is also computed, and the tributary inflows are stored in the appropriate arrays.

The subroutine PRERTE transfers the data in the initial value arrays to the current flow arrays to prepare to route any number of time steps, such as will occur with MODFLOW.

The subroutine GETBC reads boundary conditions from the file, flow.in, for a single time step.

The subroutine SETJNVL sets mixing codes for all branches and nodes to values, which indicate no routing has yet taken place.

Branches can be numbered in any order, and they are not routed in numerical order. Flows in branches that originate on the exterior boundaries must be routed first, and all branches terminating at an interior junction must be routed before any branch originating there can $b$ ? 
routed. The subroutine RTBR determines the order in which the branches will be routed, routes the flow in each individual branch, and updates the global arrays and mixing codes for both the junctions and branches. Routing in each individual branch is carried out in a subroutine called ROUTE.

The volume of water in a subreach at the beginning of the time step is passed to the subroutine FGQ. The subroutine FGQ then computes the volume of water in the subreach at the end of the time step, based on the position of the shocks and the magnitude of flow in the waves between shocks. Finally, FCQ computes the average flow out of the subreach during the time step by use of equation 1 , knowing the volumes at the beginning and end of the time step, as well as the tributary (seepage and real tributaries) and upstream flows during the time step. The flow at node one is known either from boundary conditions, for branches that originate at an exterior junction, or from the flow at the upstream junction, and the percent of flow that enters the branch that originate at an interior junction.

The subroutine SETJV2 updates the mixing codes for the branches and junctions that are affected by the computations in the branch and distributes the flow at interior junctions between the various branches that originate there. 


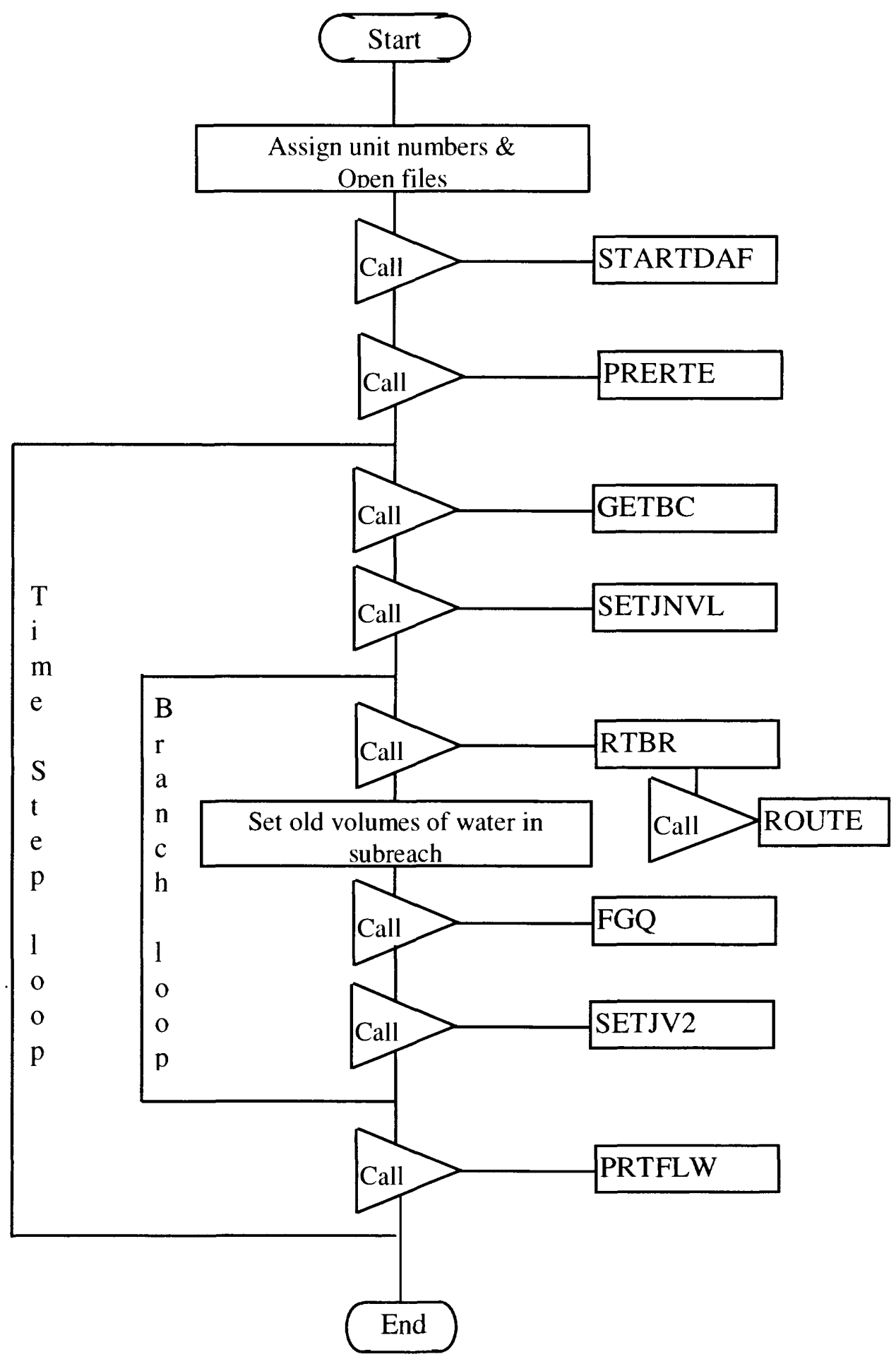

Figure 4. Overall program structure of the Diffusion Analogy Flow model. 
The subroutine PRTFLW computes the clock time, the average cross-sectional area, and ton width for the subreach. It then prints the results in the output file, as well as in the file bltm.flw'.

A file called params.inc sets parameters to define the size of arrays in DAFLOW. This file is included, by use of the INCLUDE statement, in all subroutines so that array sizes will be consistent among subroutines. It also allows array sizes to be easily adjusted to fit a particular problem. The model must be re-compiled if the array sizes are modified.

The variables that are used by the several subroutines are declared, defined, and placed in common, in files called startdaf.com and ground.com. Identical statements are placed in each subroutine by including these files as an INCLUDE statement. The three files params.inc, startdaf.com, and ground.com are listed in Appendix A along with all DAFLOW code.

The overall program structure of the combined DAFLOW/MODFLOW program is shown in figure 5. The left part of the figure represents the MODFLOW program. As shown in figure 5, calls to four subroutines were added to combine DAFLOW with MODFLOW.

A call to the DAFlAL subroutine is placed in the Allocate Procedure of MODFLOW. This subroutine first calls the subroutine STARTDAF to read the flow.in input file for DAFLOW. DAFIAL then reads the information in a second input file to determine the bed elevation, bed thickness and hydraulic conductivity of each subreach of the SW model. It also reads the layer, row, and column of the MODFLOW cell that is hydraulically connected to the subreach. If a subreach in the SW model does not interact with the GW system, zero's are entered as the layer, column, and row of the GW model. This second input file also contains the flags that control the printout for MODFLOW, debug output for the DAFLOW model, and differencing scheme used by MODFLOW. The values of these flags are also read by the subroutine. Variables that are needed for use with MODFLOW but not with the SW version of DAFLOW are declared, defined, and placed in common in a file called ground.com, which is included as needed by us of the INCLUDE statement.

A call to the DAF1AD subroutine is placed within the GW time-step loop (the Advance Procedure of MODFLOW, figure 5). This subroutine initializes arrays that will be used for numerous iterations of the SW model, determines the number of SW time steps per GW time step (NHRR), and reads, by use of GETBC, and stores the SW boundary conditions for NHRF SW time steps. 


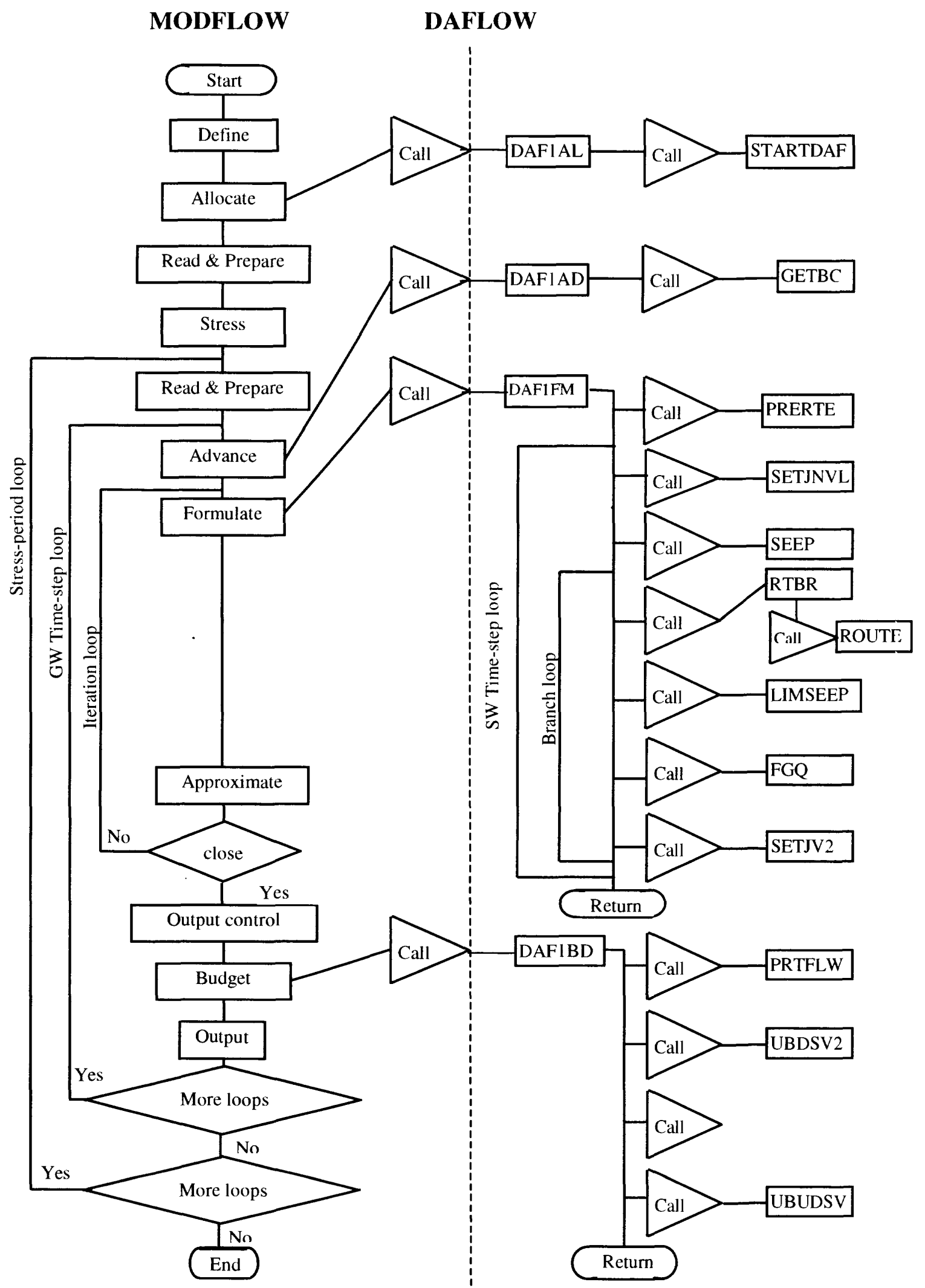

Figure 5. Overall program structure of the Diffusion Analogy Flow model linked to the Modular Finite-Difference Ground-Water Flow model. 
The actual surface-water routing is accomplished in the subroutine DAF1FM that is callec from within the GW iteration loop (the Formulate Procedure of MODFLOW, figure 5). This subroutine computes the exchange of water between the SW subreaches and the MODFLOW cells and routes the SW flow for NHRR time steps. It accomplishes this by calling subroutines of the DAFLOW model as well as two additional subroutines, SEEP and LIMSEEP.

The subroutine SEEP computes the potential exchange of water (assuming a sufficient supply of water exists in the channel) between each subreach of the DAFLOW and the corresponding aquifer cell. The hydraulic depth is computed as the cross-sectional area divided by the top width. The head in the aquifer at a time centered on the SW time step is then determined if central differencing is being used. If the aquifer head is above the elevation of the streambed layer, then the aquifer is assumed to be in hydraulic connection with the stream and the leakage is computed by use of equation 16 . If the aquifer head is below this point, it is assumed that the aquifer does not have hydraulic connection with the stream and the driving head on equation 16 is changed to the negative of the sum of the depth and the bed thickness. Leakage is assumed to be negative, in DAFLOW, when the flow is from the stream to the aquifer. Negative leakage rates are considered to be potential values because the actual leakage may be limited by the amount of water available in the stream.

Leakage computed in subroutine SEEP are combined with any tributary flow occurring at the node and treated as a single tributary exchange in DAFLOW.

If flow extractions exceed the quantity of water available in the stream, the subroutine ROUTE reduces the flow extraction to what is available.

The subroutine LIMSEEP detects any change in flow extraction and apportions the limitation between surface-water extractions and leakage to the aquifer. The available water is first given to leakage to the aquifer and any excess is provided for SW extraction. The subroutine LIMSEEP also accumulates the total exchange between the stream and aquifer for all SW time steps witl in a GW time step.

At the end of the SW time loop, the subroutine DAFIFM fills the leakage arrays for use ir MODFLOW, based on the accumulated exchange during all SW time steps.

Finally, a call to the DAFIBD subroutine is placed within the GW Budget Procedure of MODFLOW. This subroutine writes selected results for the SW flow computations for each time step by calling PRTFLW. It also calculates various budget terms for MODFLOW by calling the subroutines UBDSV2, UBDSVA, and UBUDSV. The Fortran code for all subroutines shown in figure 5 is listed in Appendix A.

\section{IMPLEMENTATION IN THE MODULAR FINITE-DIFFERENCE GROUND- WATER FLOW MODEL}

\section{Input files}

Two input files are necessary to run DAFLOW with MODFLOW. One file is identical to the input file needed to run DAFLOW alone. It defines the physical system to be modeled, specifies model options used for the simulation, and contains the boundary conditions as a function of time. In DAFLOW without MODFLOW, this file must be named flow.in, and throughout this report, it will be referred to as the flow.in file. But in the coupled version of DAFLOW and 
MODFLOW, this file can have any name. The name of the flow.in file is specified in the MODFLOW name file. The MODFLOW name file specifies all of the files used in a MODFLOW simulation. One line is used for each file, and this line consists of the file type, file unit, and file name. The file type for the flow.in file must be DAF. For example, the following line indicates that the flow.in file will be named test.inf:

DAF 42 test.inf .

The information contained in flow.in is divided into three data groups: (1) general information, (2) branch information, and (3) boundary conditions.

Table 1 is a summary description of the input data records as required in the file flow.in.

Table 1.--Input format for the Diffusion Analogy Flow Model

Data Group 1 - General information

\begin{tabular}{|c|c|c|c|c|}
\hline$\underline{\text { Record }}$ & Field & Variable & Format & Description \\
\hline & 1 & TITLE & A80 & Title of simulation \\
\hline 2 & 1 & NBRCH & $20 X, I 10$ & Number of branches \\
\hline 3 & 1 & NJNCT & $20 \mathrm{X}, \mathrm{I1} 0$ & Number of interior junctions \\
\hline 4 & 1 & NHR & $20 \mathrm{X}, \mathrm{I} 10$ & Number of time steps to be modeled \\
\hline 5 & 1 & JTS & $20 X, I 10$ & $\begin{array}{l}\text { Number of time steps between midnight and the } \\
\text { start of the simulation }\end{array}$ \\
\hline 6 & 1 & JGO & $20 \mathrm{X}, \mathrm{I} 10$ & $\begin{array}{l}\text { Number of time steps between printouts in } \\
\text { FLOW.OUT }\end{array}$ \\
\hline 7 & 1 & IENG & $20 \mathrm{X}, \mathrm{I} 10$ & $\begin{array}{l}\text { Input units }[0=\text { metric (length unit is meters except } \\
\text { for river miles), } 1=\text { English (length unit is feet } \\
\text { except river miles)] }\end{array}$ \\
\hline 8 & 1 & DT & $20 X, F 10.3$ & Time-step size in hours \\
\hline 9 & 1 & QP & $20 X, F 10.0$ & $\begin{array}{l}\text { Maximum discharge of interest ("peak discharge"), } \\
\text { discharge below QP/100000.0 will be considered to } \\
\text { be zero }\end{array}$ \\
\hline
\end{tabular}


Table 1.--Input format for the Diffusion Analogy Flow Model--continued

Data Group 2 - Branch information

(one set required for each branch)

(Record 3 is repeated for each node in the branch)

\begin{tabular}{|c|c|c|c|c|}
\hline Record & Field & Variable & Format & Description \\
\hline 1 & 1 & NXSEC $(N)$ & $13 \mathrm{X}, \mathrm{I} 3$ & Number of nodes (cross sections) in branch $\mathrm{N}$ \\
\hline 1 & 2 & $\mathrm{PF}(\mathrm{N})$ & $16 \mathrm{X}, \mathrm{F} 5.2$ & $\begin{array}{l}\text { Fraction of flow at upstream junction to enter } \\
\text { branch } \mathrm{N}\end{array}$ \\
\hline 1 & 3 & JNCU (N) & $16 \mathrm{X}, \mathrm{I} 3$ & Junction number at upstream end of branch $\mathrm{N}$ \\
\hline 1 & 4 & $\mathrm{JNCD}(\mathrm{N})$ & $8 \mathrm{X}, \mathrm{I} 3$ & Junction number at downstream end of branch $N^{\top}$ \\
\hline 2 & 1 & --- & A & Header card for information only \\
\hline 3 & 1 & I & $\mathrm{I} 3$ & Node of data in record \\
\hline 3 & 2 & $X(N, I)$ & $\mathrm{G} 11.4$ & $\begin{array}{l}\text { Distance of node } \mathrm{I} \text { of branch } \mathrm{N} \text { from reference point } \\
\text { in miles }\end{array}$ \\
\hline 3 & 3 & IOUT $(\mathrm{N}, \mathrm{I})$ & $\mathrm{I} 2$ & $\begin{array}{l}\text { Output flag (equal } 1 \text { if output in BLTM.OUT is } \\
\text { desired for this node, } 0 \text { otherwise) }\end{array}$ \\
\hline 3 & 4 & $\mathrm{~F}(\mathrm{~N}, \mathrm{I})$ & G11.4 & Initial flow in subreach I (between node I and I+1) \\
\hline 3 & 5 & Al $(\mathrm{N}, \mathrm{I})$ & G10.3 & Constant $\mathrm{A} 1$ in equation 3 for subreach I \\
\hline 3 & 6 & A2 $(\mathrm{N}, \mathrm{I})$ & G10.3 & Constant $\mathrm{A} 2$ in equation 3 for subreach I \\
\hline 3 & 7 & $\mathrm{~A} 0(\mathrm{~N}, \mathrm{I})$ & G10.3 & Constant $\mathrm{A} 0$ in equation 3 for subreach I \\
\hline 3 & 8 & $\operatorname{SL}(N, I)$ & G10.3 & Bed slope of subreach, in $\mathrm{ft} / \mathrm{ft}$ or $\mathrm{m} / \mathrm{m}$ \\
\hline 3 & 9 & W $1(\mathrm{~N}, \mathrm{I})$ & F7.1 & Constant W 1 in equation 4 for subreach I \\
\hline 3 & 10 & $\mathrm{~W} 2(\mathrm{~N}, \mathrm{I})$ & F7.6 & Constant W2 in equation 4 for subreach I \\
\hline \multicolumn{5}{|c|}{$\begin{array}{l}\text { Data Group } 3 \text { - Boundary condition } \\
\text { (one set for each time step) }\end{array}$} \\
\hline
\end{tabular}

\begin{tabular}{|c|c|c|c|c|}
\hline Record & Field & Variable & Format & Description \\
\hline 1 & 1 & NBC & $18 \mathrm{X}, \mathrm{I} 3$ & $\begin{array}{l}\text { Number of new boundary conditions to be input for } \\
\text { this time step }\end{array}$ \\
\hline 2 & 1 & $\mathrm{~N}$ & $10 \mathrm{X}, \mathrm{I} 3$ & Branch number for new boundary condition \\
\hline 2 & 2 & I & $5 \mathrm{X}, \mathrm{I} 3$ & Node number for new boundary condition \\
\hline 2 & 3 & $\mathrm{TRB}(\mathrm{I}, \mathrm{N})$ & $3 \mathrm{X}, \mathrm{G} 14.5$ & New boundary flow for branch $\mathrm{N}$, node I \\
\hline
\end{tabular}

The first data group consists of nine records that define parameters to control the simulation. The title is specified as any combination of letters, symbols, or numbers of up to 80 characters in length. It will be printed in the output file for identification purposes but otherwise is not used. The remaining lines of the general information are read as formatted input so it is important that the numbers be placed in columns 21 to 30 . The number of branches is self evident and only the number of interior junctions, not total junctions, is input as the third record. An interior junctic $n$ is one that connects two or more branches. The number of time steps in the simulation is calculated as the duration of the simulation divided by the SW time-step size, expressed in hours. The time reference for the simulation is midnight of the first day of the simulation. This is 
specified to the model as the number of time steps from midnight to the start of the simulation. For example, if the simulation is to begin at 06:00 hours and the time-step size is 0.5 hours, the value specified for JTS is 6 divided by 0.5 , which equals 12 time steps. The printout frequency is specified in terms of the number of time steps between printouts. For example, if tabular flow information is desired every 3 hours and the time-step size is 0.5 hours, the value of JGO is specified as 3 divided by 0.5 , which equals 6 time steps. The length units are specified as either $1=$ English ( $\mathrm{ft}$ ) or $0=$ metric (meter), except that the distance to node points (specified in data group 2) is input as either miles or kilometers. The time-step size is input in hours. DAFLOW uses an iterative solution scheme, such that its solutions must converge to a given tolerance. DAFLOW assumes that discharges (cubic feet or meter per second), differences in discharges, and water volumes divided by the time-step size, which are less than a tolerance, to be insignificant (nearly zero). The model calculates the tolerance from a given "peak" discharge divided by 100,000 . This peak discharge should be larger than the maximum discharge expected during the simulation. It follows that the accuracy of the model results can be no better than this tolerance value. If the tolerance value is set too small, the program may not converge because the tolerance is smaller than the round-off error of flows carried in computer memory.

Data group two consists of two types of records: (1) branch record, (2) node/subreach records. The branch record specifies the number of nodes (cross sections) in the branch, the fraction of flow at the upstream junction that enters the branch, and the upstream and downstream junction numbers. When more than one branch originates at a junction, the water that enters the junction is split between these outgoing branches. This is specified to the model as the fraction of flow to enter the branch. For example, if two branches receive equal amounts of flow from the junction, this value should be specified as 0.5 for each branch. If only one branch receives flow from a junction (the most common case), this value is specified as 1.0 .

A header line follows the branch information to define the columns of data for the nodes or subreaches. The model ignores this line so it could be simply a blank line. The node records define the node number, location of the node in miles or kilometers, an output flag, for each node and the initial flow, hydraulic-geometry parameters and slope for each subreach. The hydraulicgeometry exponents are independent of the system of units, but the hydraulic-geometry coefficients are dependent upon the units used. The number of node-records input must equal the number specified on the branch record. Node records are input in sequence starting with tha node 1 , at the upstream end of the branch. The node location is specified as the distance to the cross section from a reference point at or above the upstream end of the branch. The initial disclarge, slope, and all coefficients apply to the subreach extending from the node for which it is spacified to the next node downstream. For example, the value of A1 input for node 1 applies to the subreach extending from node 1 to node 2 . Because there is no subreach downstream of the last node, only the river mile and output flag needs to be specified for the last node. The model is based on the assumption that tributaries enter the stream just upstream of the node. The initial discharge for subreach I, therefore, should include the effect of the tributary flow at node I. The output flag (IOUT) specifies whether or not the flow information for the node is to be printed in the output file. The data at each node is read as a free-field format, so it is not necessary to keep the numbers in any particular column or even to line them up. It is necessary that at least one blank space separate each number and that a number be available for each variable. Exponential formats (see slope) are acceptable. The formats shown in Table 1 are used if the file is created interactively using the program BDAFLOW (Jobson, 1989). 
Boundary conditions must represent the average flow during the time step. For example, the first boundary condition should represent the average flow between time 0 and the end of the first time step. For the first time step, all boundary conditions should be entered because DAFLOW assumes all unspecified boundary conditions to be zero. After the first time step, however, DAFLOW assumes all boundary conditions remain constant unless specifically changed. The third data group is used to input boundary conditions and consists of two types of records. The first record for each time step specifies the number of boundary conditions that have changed for this time step (NBC). A line for each boundary condition that has changed must follow. For example, if $\mathrm{NBC}=0$, no records are required but if $\mathrm{NBC}=5$, five records must follow. The second type of record specifies the branch number, node number, and flow for the changed boundary condition. Data group 3 must be input for each time step of the simulation. The first record is always required, whereas the second record is only required if one or more boundary conditions are changed.

An example input file is shown in figure 6 for the network shown in figure 2.

The input file shown in figure 6 has a header line identifying the data that is to follow. As indicated in the next eight lines; the model has three branches and one internal junction, it will run 5 time steps, the model starts at midnight (starts 0 time steps after midnight), output will te printed every time step, English units will be used (IENG $=1$ ), the time-step size is 1.0 hour, and flows less than $1.0 \mathrm{ft}^{3} / \mathrm{s}(100,000 / 100,000)$ will be considered to be insignificant. Numbers for these variables must be placed within the columns 21 through 30 and the last two should contain decimal points. 


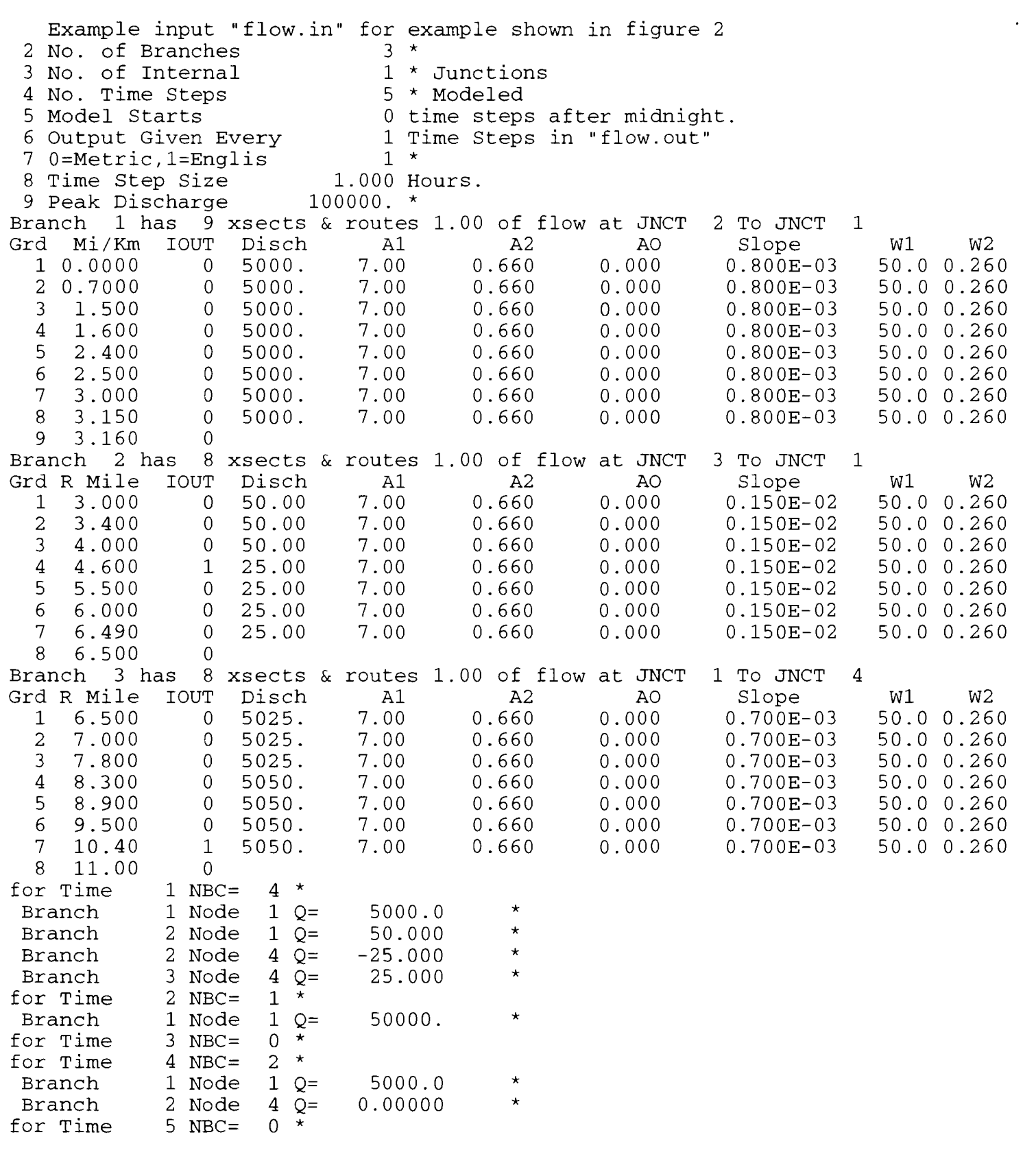

Figure 6. Input file, flow.in, to run the example shown in figure 2. 
The next group contains the branch and node information. The first line of this group indicates that branch 1 contains 9 nodes and routes 100 percent of the flow at junction 2 to junction 1. The numbers on this line need to be in the columns indicated in Table 1 . The next line is ignored, but it is recommended to place column headings here. Following the column header is one line of data for each of the 9 nodes in branch 1. The first line indicates that node 1 is located at mile 0.0 , that output is not to be printed (IOUT $=0$ ), the initial discharge in the subreach (frc $\mathrm{m}$ node 1 to node 2) is $5,000 \mathrm{ft}^{3} / \mathrm{s}$, and the slope and hydraulic-geometry parameters for the subreach extending from node 1 to 2 are as indicated. There is no initial discharge or hydraulicgeometry information for node 9 , because these values represent subreach average values, anc the branch has only 8 subreaches.

Notice that node 9 is only 0.01 mile below node 8 , thereby minimizing the reach length for which seepage is not allowed. Branch 1 begins at the aquifer boundary, whereas branch 2 begins upstream of the aquifer boundary and branch 3 extends below the aquifer boundary. Steady-state conditions, with no leakage to the aquifer, are assumed to have occurred for some time before the start of the model so the initial discharge at node 4 of branches 2 and 3 reflects only the tributary exchanges. The flow at node 1 in branch 3 also represents the sum of the flows at the downstream ends of branches 1 and 2. Although assumed to be constant here, the slopes, initial discharges, and hydraulic-geometry parameters generally will be different for each subreach and branch. Notice a header line is placed above the node information for each branch.

The boundary conditions follow the branch information. In this example, only 5 time steps were assumed. All external boundary conditions (flows at exterior upstream junctions, and all interior nodes) are assumed to be zero until given a value in the boundary conditions section. So four boundary conditions are needed for the first time step to define the flow at node 1 of branches 1 and 2, and at node 4 of branches 2 and 3. All boundary conditions are read as formatted data so it is important for the numbers to be in the correct columns. All boundary conditions are assumed to remain constant until changed by new input. In this case the flow at node 1 , branch 1 is assumed to change from 5,000 to 50,000 at the beginning of the second time step and to change back to 5,000 at the beginning of the fourth time step. The flows at branch 2 , node 1 and branch 3, node 4 are assumed to remain constant for the entire run so only the entry at the first time step is needed. The flow at node 4 , branch 2 changes from -25 to 0 at time step 4 .

When DAFLOW is linked to MODFLOW, input information is required in addition to wh at is contained in the flow.in file. This information is contained in a file that has file type DAFG in the MODFLOW name file. The first 80 characters of the first three lines of the DAFG file are simply read in as text and printed in the MODFLOW output file for information purposes. It is recommended that the first line contain identifying information, and the second two lines contain column headings to identify the eight data fields that will follow. Examples of the column headings are shown in figure 7, which contains input data for the example shown in figure 2. Following the three header lines, eight fields of bed property and linkage information are needed for each interior node of each SW branch. The data fields include; (1) branch number, (2) node number, (3) bed elevation of subreach upstream of the node, (4) average bed thickness of the subreach, (5) bed hydraulic conductivity of subreach, and (6), (7), (8) layer, row, and column number respectively, of the cell in MODFLOW that is in hydraulic connection with the subreach. These columns of information are read using free format so it is not important that the numbers be in any particular column or that the numbers line up. It is necessary, however that there be at least one blank space between each data field and that a number be available for each field. $T$-re 
must be one row of data for each interior node of each branch. For example, branch 1 contains nine nodes so seven entries are needed, for nodes 2 through 8 . Node 2 defines the ground-water interaction for subreach 1 and GW interaction is not allowed for the last subreach. If a SW subreach is not connected to a GW cell enter zero for the layer, row, and column numbers.

Following the bed properties and linkage information is another line of text information that can be used to identify the three parameters that are input as the last line of the file. If the first parameter (IDAFCB) is an integer less than zero, the cell-by-cell flows will be printed to the output file, if it is an integer greater than zero they will be saved to a file. If the second parameter (IDBG) is set to 1, extra debugging information will be written to the output file, otherwise it will not. This parameter should normally be set to zero (not 1) because the debug information generates a large volume of output. The third parameter (IDAFBK) specifies whether central or backwards differencing will be used for ground-water heads in MODFLOW. Enter a zero if central differencing is to be used. Any integer, other than zero, causes backwards differencing to occur. These integers can be placed in any column as long as they are separated by at least one blank space.

Figure 7 contains an example DAFG file that could be used to run the example problem shown in figure 2. The streambed elevations for this example are computed on the basis of the assumption that the elevation of node 1 , in branch 1 is $100 \mathrm{ft}$, and the bed slopes are as shown in figure 6. For example, figure 2 shows that the subreach upstream of node 2 in branch 1 sho'ld be in communication with row 1, column 1 of the aquifer, and it is assumed that only one layer is involved. The elevation of the bed for this subreach is estimated as the elevation of the midpoint of the subreach. So it should be the elevation of node 1 (100) minus the slope $(0.0008=4.2 .24$ $\mathrm{ft} / \mathrm{mile})$ times one-half the subreach length $(0.7-0.0$ mile $)$, or $98.522 \mathrm{ft}$.

Also, notice that there is no connection for node 2 , branch 2 (subreach 1 ) with the aquifer so zeros are entered for the layer, row, and column of the interaction. Leakage from all three branches interact with cell 3,3. The thickness of the streambed layer is assumed to be $1.0 \mathrm{ft}$, and the hydraulic conductivity of the bed layer is assumed to be $0.00120 \mathrm{ft} / \mathrm{s}$ for all subreaches.

Because IDAFCB is greater than zero, the cell-by-cell flows will be saved to a separate file rather than printed to the output file. The code IDBG is not equal to 1 so the extensive debug printout will not be listed. Because IDAFBK is not equal to zero, backwards differencing w'ill be used in MODFLOW. 


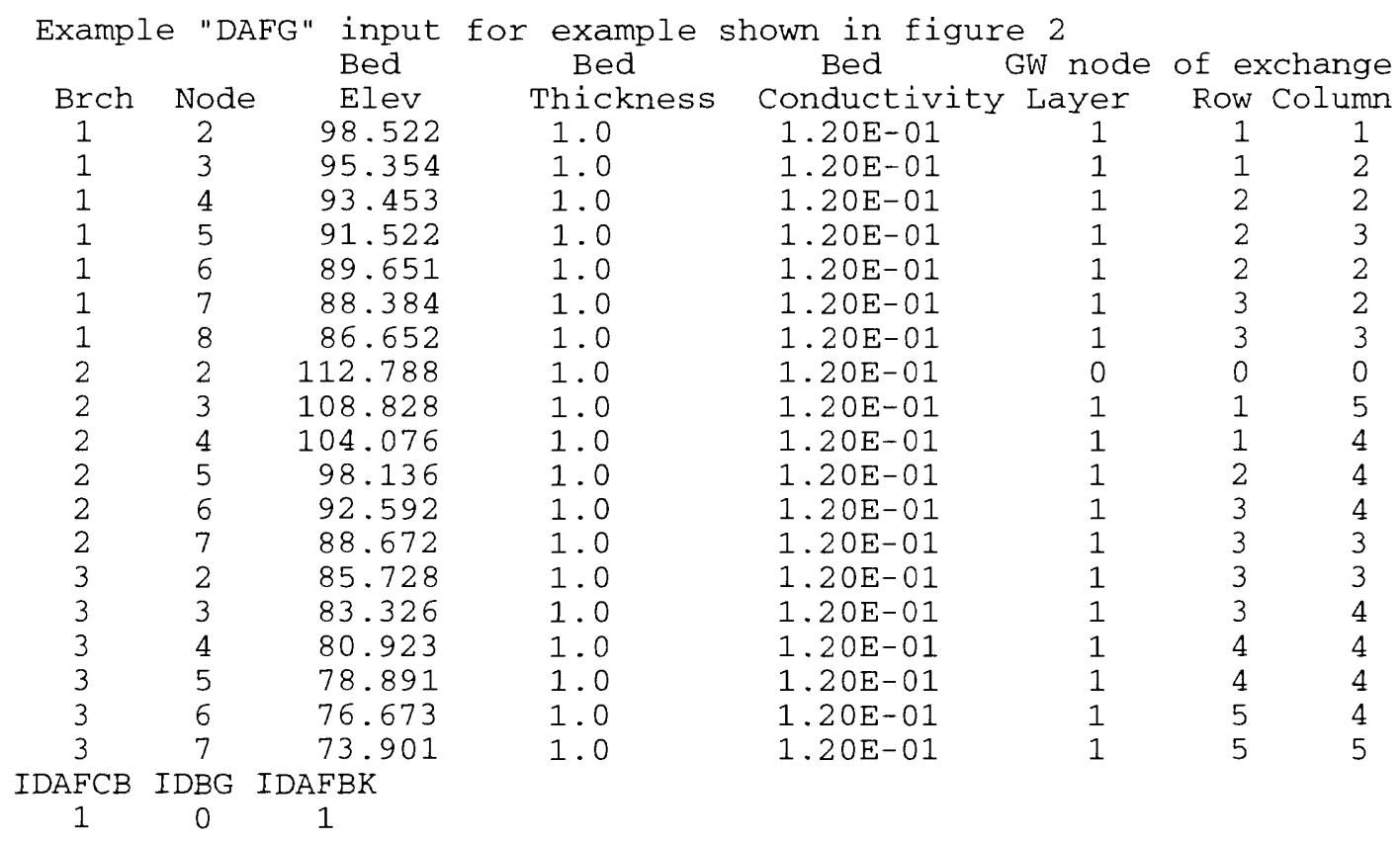

Figure 7. Input file, DAFG, to run the example shown in figure 2.

\section{Output files}

The output of the DAFLOW model is written to two files: a bltm.flw, file and the standard output file of MODFLOW. The information in the MODFLOW output file is designed to provide tabular information summarizing the simulation and, the bltm.flw file provides flow field information for plotting or other post-processing programs. The bltm.flw file is specified in the MODFLOW name file using file type DAFF.

The DAFLOW model echoes the input information from the flow.in and DAFG files into the MODFLOW output file as well as presenting a summary of the simulation results at the selected nodes and time frequency. This summary consists of the time, branch number, node number, and the average flow during the time step at the node. If the debug option is selected (IDBG=1), a detailed summary of the results is written to the MODFLOW output file. The debug option is useful if a problem is encountered with the model, and it is desired to investigate further where and (or) why the problem is occurring. Because it generates a large volume of output, the debug option should not be used unless specific problems are suspected.

The second output file, the bltm.flw file, contains flow information at every node for eact time step of the simulation. This information includes the channel flow rate, cross-sectional area, top width, and tributary flow. The node and tributary flow represent the average flow during the SW time step, and the area and top width represent the instantaneous values at the end of the 
time step, but averaged over the subreach. The cross-sectional area for the subreach is computed as the volume of water in the subreach divided by the length of the subreach. The width is computed on the basis of the area and the hydraulic-geometry relations used by DAFLOW. The information in the bltm.flw file is designed to be used to provide hydraulic information to a transport model, like the BLTM model (Jobson and Schoellhamer, 1987), or to be used with post-processor programs.

\section{EXAMPLE APPLICATIONS}

\section{Example 1, Streamflow resulting from variable recharge, comparison with an analytical solution}

The first example will compare simulated results with an analytical solution developed by Oakes and Wilkinson (1972) using the grid and aquifer properties assumed by Prudic (1989). The example consists of an idealized unconfined aquifer with a stream flowing north to south as shown in figure 8 . The width of the aquifer perpendicular to the stream is $4,000 \mathrm{ft}$ on each side, while the length parallel to the stream is $13,000 \mathrm{ft}$. The transmissivity, and storage coefficient of the aquifer are $0.037 \mathrm{ft}^{2} / \mathrm{s}$ and 0.20 respectively. The streambed thickness is assumed to be 1 foot. The product of the streambed hydraulic conductivity and the stream width is assumed to be equal to $0.037 \mathrm{ft}^{2} / \mathrm{s}$. Other assumptions used in both the analytical solution and the model simulation include:

1. The lateral boundaries of the aquifer are impermeable (no flow is allowed).

2. The layer beneath the aquifer are impermeable.

3. The stream penetrates the entire depth of the aquifer and has vertical banks.

4. The transmissivity and storage coefficient are constant throughout the aquifer and remain constant in time.

5. The aquifer is unconfined and Darcy's Law is valid.

6. The flow of ground water is horizontal.

7. The water level in the stream is constant along its length and with time.

8. The infiltration of recharge to the aquifer is instantaneous (no delay between the time precipitation infiltrates the surface until it reaches the water table).

9. The discharge from the aquifer is only to the stream. 


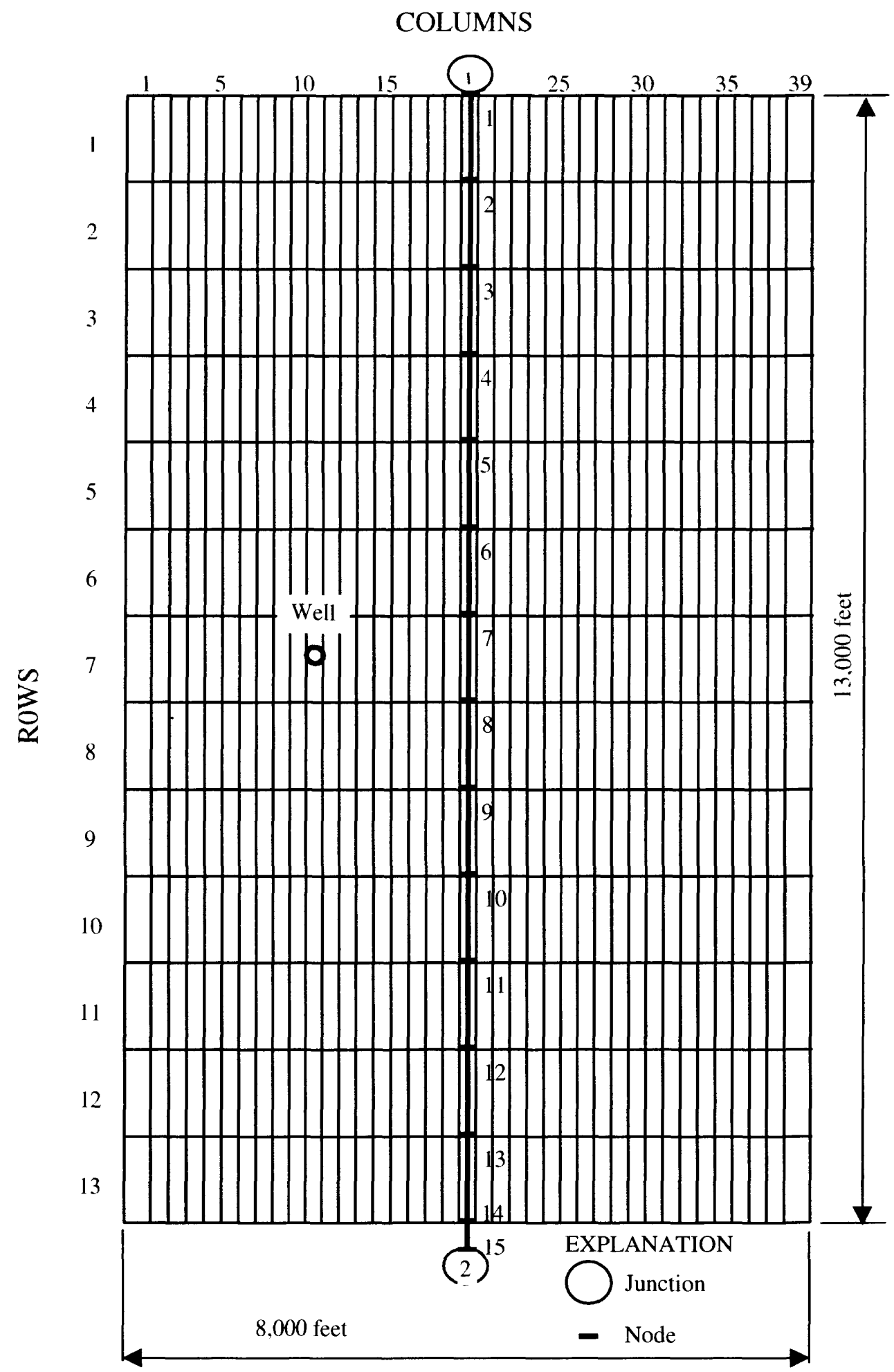

Figure 8. Aquifer grid of example 1 with surface-water model grid superimposed. 
The analytical solution provides the stream discharge and the ground-water elevations as a function of time for a system in equilibrium with the periodic recharge function shown on figure 9. The total "annual" (360 days) recharge is $1.5 \mathrm{ft}$ and is applied evenly over the aquifer. The daily recharge rate has a sinusoidal distribution for the first 180 days and is zero for the next 180 days.

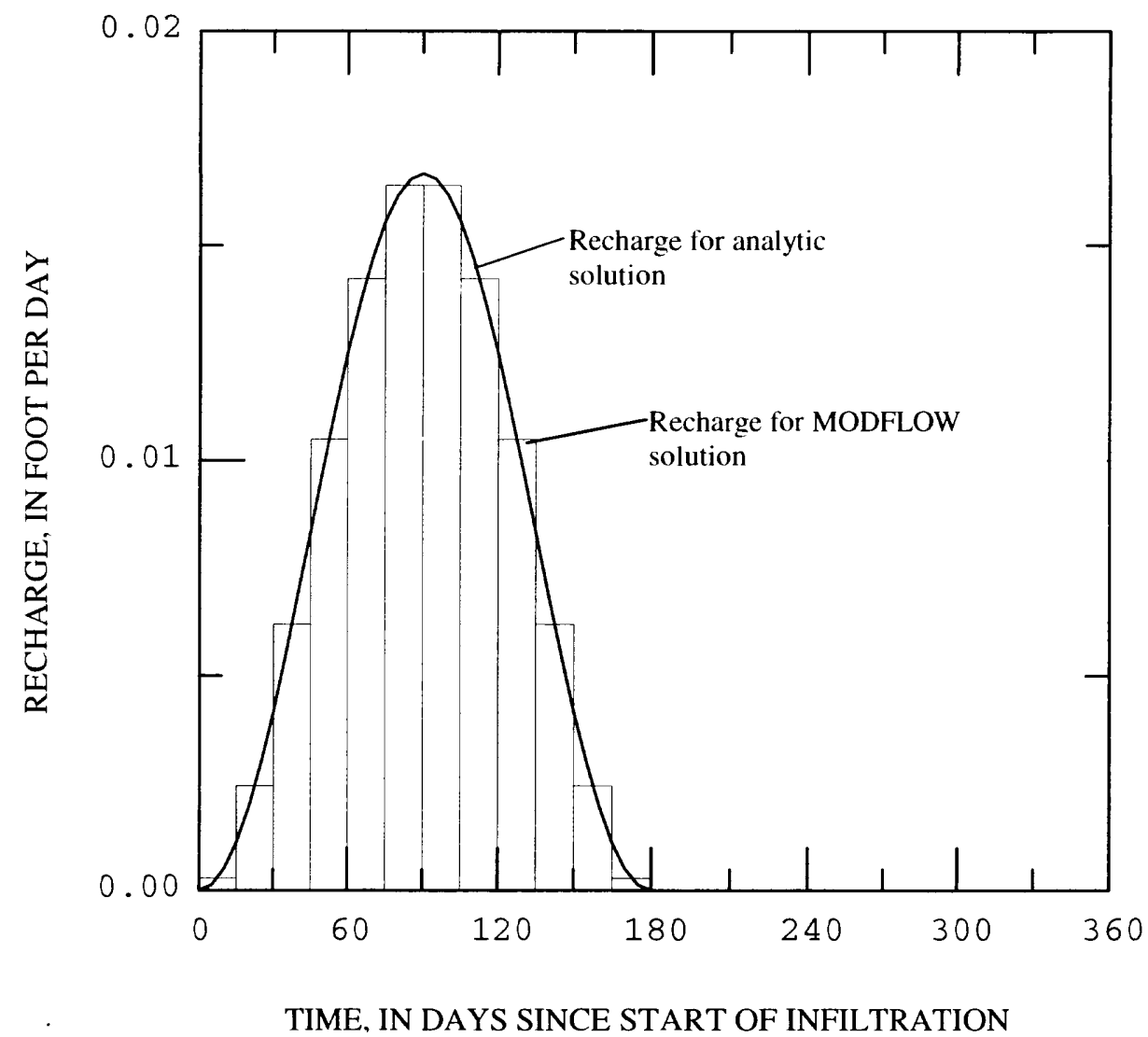

Figure 9. Distribution of recharge used for the analytical and numerical simulation of example 1.

As illustrated on figure 8 , the aquifer was represented in the MODFLOW model by a grid with 39 columns and 13 rows. Each cell was $1,000 \mathrm{ft}$ long and $200 \mathrm{ft}$ wide, except for cells in columns 1 and 39, which were $300 \mathrm{ft}$ wide. The stream ran vertically through the center of column 20 . The initial heads in the aquifer were assumed to be the heads from the analytical solution for time zero at the center of each cell. The annual cycle was represented in MODILOW by 24 stress periods, each 15-days long. Each stress period was divided into two, 7.5 day time steps. Equilibrium conditions were assumed to have been reached after 5 annual cycles.

Assumption 7 implies that the stream has a slope of zero and a constant depth under varying flow conditions. Such assumptions are physically impossible and can not be duplicated exa tly by DAFLOW. The DAFLOW solution is based on the assumption that the stream had a small slope, a constant depth, and nearly constant width and area. This was accomplished by assuming 
the area and width of the stream are described by the hydraulic-geometry parameters shown ir figure 10. For these assumed hydraulic-geometry parameters, the cross-sectional area and wid' $h$, respectively, vary from $398.4 \mathrm{ft}^{2}$ and $99.60 \mathrm{ft}$ at a discharge of $10 \mathrm{ft}^{3} / \mathrm{s}$ to $401.2 \mathrm{ft}^{2}$ and $100.3 \mathrm{ft}^{+}$at a discharge of $20 \mathrm{ft}^{3} / \mathrm{s}$. Dividing each area by the top width, yields a constant hydraulic depth of $4.00 \mathrm{ft}$. The slope, which is only used by DAFLOW to compute the diffusion of the flow waves along the channel, was set at a small value of 0.0001 . The bed elevation of each subreach in tha flow model, which is not used by the hydraulic calculations in DAFLOW, was set at a constant value of $46.00 \mathrm{ft}$. So as far as MODFLOW is concerned, the water surface elevation is constant at $50.000 \mathrm{ft}$ for all times and locations. The contact area between the stream and the aquifer (width) varies by about 1 percent as the discharge doubles from 10 to $20 \mathrm{ft}^{3} / \mathrm{s}$. For the high hydraulic conductance chosen for this example, the results are insensitive to variations in channel width.

The DAFLOW input file, flow.in, for the example is shown in figure 10. As shown in figure 8 , branch 1 begins at junction 1 , which is located at the upstream boundary of the aquifer in th: middle of column 20. Branch 1 contains 15 nodes, with 14 located at the points where the stream crosses the boundary between each row plus a node at junction 2 , which is downstream of the aquifer. DAFLOW is set to run for 288 time steps, each 180 hours ( 7.5 days) long for a total time of six, 360-day years. The peak discharge is set at $100 \mathrm{ft}^{3} / \mathrm{s}$, which indicates that DAFLOW ignores discharges of less than $0.001 \mathrm{ft}^{3} / \mathrm{s}$. The first 14 nodes are spaced 0.189 miles $(1,000 \mathrm{ft})$, and output is to be listed for nodes 7 and 15. The initial base-flow discharge is $10 \mathrm{ft}^{3} / \mathrm{s}$. The only boundary condition is for the upstream boundary at time step 1, which sets the inflow at $10 \mathrm{ft}^{3} / \mathrm{s}$. The inflow remains constant at $10 \mathrm{ft}^{3} / \mathrm{s}$ for the duration of the simulation. The actual file would have 288 entries for boundary conditions, all except the first, indicating that zero boundary conditions are changed $(\mathrm{NBC}=0)$. 


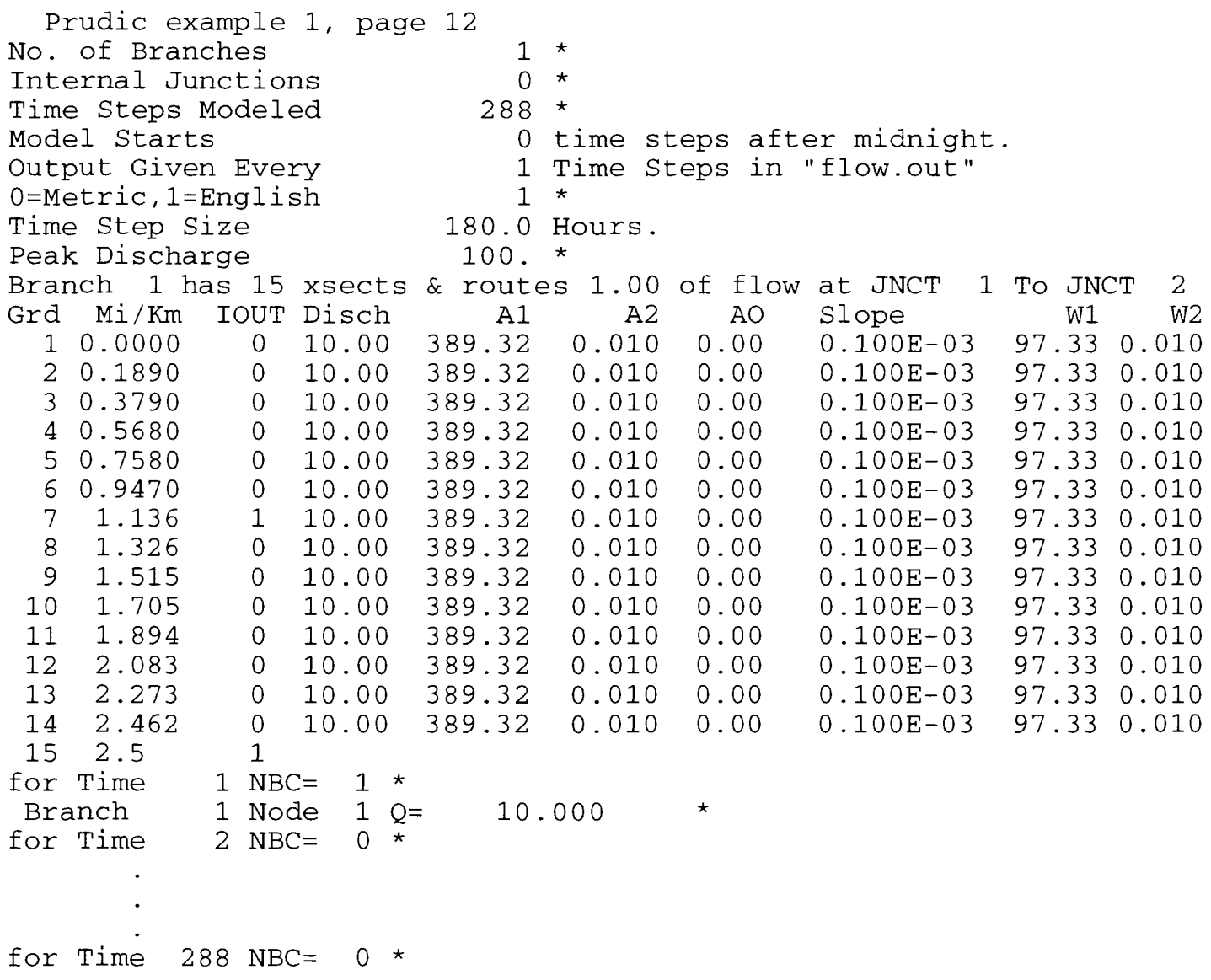

Figure 10. Input file, flow.in, for example 1.

Information not needed by DAFLOW for a purely surface-water model is contained in the DAFG file. A listing of this file is shown in figure 11. Notice that data are required for nodes 2 through 14 , but not for nodes 1 or 15 . The columns are not necessarily aligned. The actual format of these data is not important as long as values are included in each data field and that the data are separated by at least one space. The hydraulic conductivity times the stream width was assumed to be $0.037 \mathrm{ft}^{2} / \mathrm{s}$ in the analytical model. The stream width is $100.0 \mathrm{ft}$ so the hydraulic conductivity is input as $0.00037 \mathrm{ft} / \mathrm{s}$. Only one layer is used in the ground-water model, and all stream nodes are in column 20 . Node 2 is associated with row 1 , and each succeeding node is associated with the next row. IDAFCB is zero, which means that cell-by-cell flows for each stream node will not be saved to a file or written to the listing file. If IDAFCB is less than then zero, the flows will be printed to the output file. If IDAFCB is an integer greater than zero, the flows will be saved to a file. Because IDBG is equal to zero, the DAFLOW debug printouts will not be written. Backwards differencing will be used in MODFLOW because IDAFBK is not equal to zero. 


\begin{tabular}{|c|c|c|c|c|c|c|c|}
\hline & & Bed & Bed & & GW node & of ex & rchange \\
\hline Brch & Node & Elev & Thickness & Conductivity & Layer & Row & Column \\
\hline 1 & 2 & 46.00 & 1.00 & $3.70 E-04$ & 1 & 1 & 20 \\
\hline 1 & 3 & 46.00 & 1.0 & $3.70 E-04$ & 1 & 2 & 20 \\
\hline 1 & 4 & 46.00 & 1.0 & $3.70 E-04$ & 1 & 3 & 20 \\
\hline 1 & 5 & 46.00 & 1.0 & $3.70 E-04$ & 1 & 4 & 20 \\
\hline 1 & 6 & 46.00 & 1.0 & $3.70 E-04$ & 1 & 5 & 20 \\
\hline 1 & 7 & 46.00 & 1.0 & $3.70 E-04$ & 1 & 6 & 20 \\
\hline 1 & 8 & 46.00 & 1.0 & $3.70 E-04$ & 1 & 7 & 20 \\
\hline 1 & 9 & 46.00 & 1.0 & $3.70 E-04$ & 1 & 8 & 20 \\
\hline 1 & 10 & 46.00 & 1.0 & $3.70 E-04$ & 1 & 9 & 20 \\
\hline 1 & 11 & 46.00 & 1.0 & $3.70 E-04$ & 1 & 10 & 20 \\
\hline 1 & 12 & 46.00 & 1.0 & $3.70 E-04$ & 1 & 11 & 20 \\
\hline 1 & 13 & 46.00 & 1.0 & $3.70 E-04$ & 1 & 12 & 20 \\
\hline 1 & 14 & 46.00 & 1.0 & $3.70 E-04$ & 1 & 13 & 20 \\
\hline IDAFC & IDBG & IDAFBK & & & & & \\
\hline 0 & 0 & 1 & & & & & \\
\hline
\end{tabular}

Figure 11. Input file, DAFG, for example 1.

All additional input files for MODFLOW are shown in Appendix B.

Selected output of the MODFLOW/DAFLOW model is given in figure 12 for stress period 134 that is near the end of the recharge period of the final year of simulation. The elevations are given for only one row because all rows have equal heads (the water surface has zero slope parallel to the stream). This confirmed the one-dimensional nature of the MODFLOW solution. For a given node and day of the year, the streamflows were the same for any year (within 0.01 $\mathrm{ft}^{3} / \mathrm{s}$ ) after the first year of simulation. Variability in flows between the first and the last year were generally within $0.04 \mathrm{ft}^{3} / \mathrm{s}$. One note of caution may be in order. The surface-water flow results represent the average during the SW time step and are, therefore, shown to occur at the midpoint of the time step (Day 2007, Hour 6.0). The heads in the aquifer, on the other hand, are those occurring at the end of the time step. For the example shown, this is for stress period 134, which is at the end of day 2010 (day 210 of year 6). The difference in these times is 3.75 days, one half of the 7.5 day time step of the SW model. 
STRESS PERIOD NO. 134, LENGTH $=1296000$.

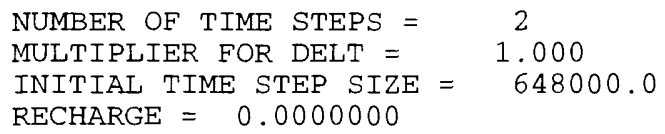

HEAD IN LAYER 1 AT END OF TIME STEP 2 IN STRESS PERIOD 134

\begin{tabular}{|c|c|c|c|c|c|c|c|c|c|}
\hline $\begin{array}{r}1 \\
11 \\
21 \\
31\end{array}$ & $\begin{array}{r}2 \\
12 \\
22 \\
32\end{array}$ & $\begin{array}{r}3 \\
13 \\
23 \\
33\end{array}$ & $\begin{array}{r}4 \\
14 \\
24 \\
34\end{array}$ & $\begin{array}{r}5 \\
15 \\
25 \\
35\end{array}$ & $\begin{array}{r}6 \\
16 \\
26 \\
36\end{array}$ & $\begin{array}{r}7 \\
17 \\
27 \\
37\end{array}$ & $\begin{array}{r}8 \\
18 \\
28 \\
38\end{array}$ & $\begin{array}{r}9 \\
19 \\
29 \\
39\end{array}$ & $\begin{array}{l}10 \\
20 \\
30\end{array}$ \\
\hline $\begin{array}{l}31.805 \\
58.136 \\
51.039 \\
59.368\end{array}$ & $\begin{array}{l}61.694 \\
57.425 \\
52.058 \\
59.889\end{array}$ & $\begin{array}{l}61.546 \\
56.655 \\
53.055 \\
60.346\end{array}$ & $\begin{array}{l}61.338 \\
55.827 \\
54.021 \\
60.739\end{array}$ & $\begin{array}{l}61.069 \\
54.947 \\
54.947 \\
61.069\end{array}$ & $\begin{array}{l}60.739 \\
54.021 \\
55.827 \\
61.338\end{array}$ & $\begin{array}{l}60.346 \\
53.055 \\
56.655 \\
61.546\end{array}$ & $\begin{array}{l}59.889 \\
52.058 \\
57.425 \\
61.694\end{array}$ & $\begin{array}{l}59.368 \\
51.039 \\
58.136 \\
61.805\end{array}$ & $\begin{array}{l}58.784 \\
50.010 \\
58.784\end{array}$ \\
\hline
\end{tabular}

Figure 12. Selected output of the Modular Finite-Difference Ground-Water Flow model results at stress period 134, for example 1. 


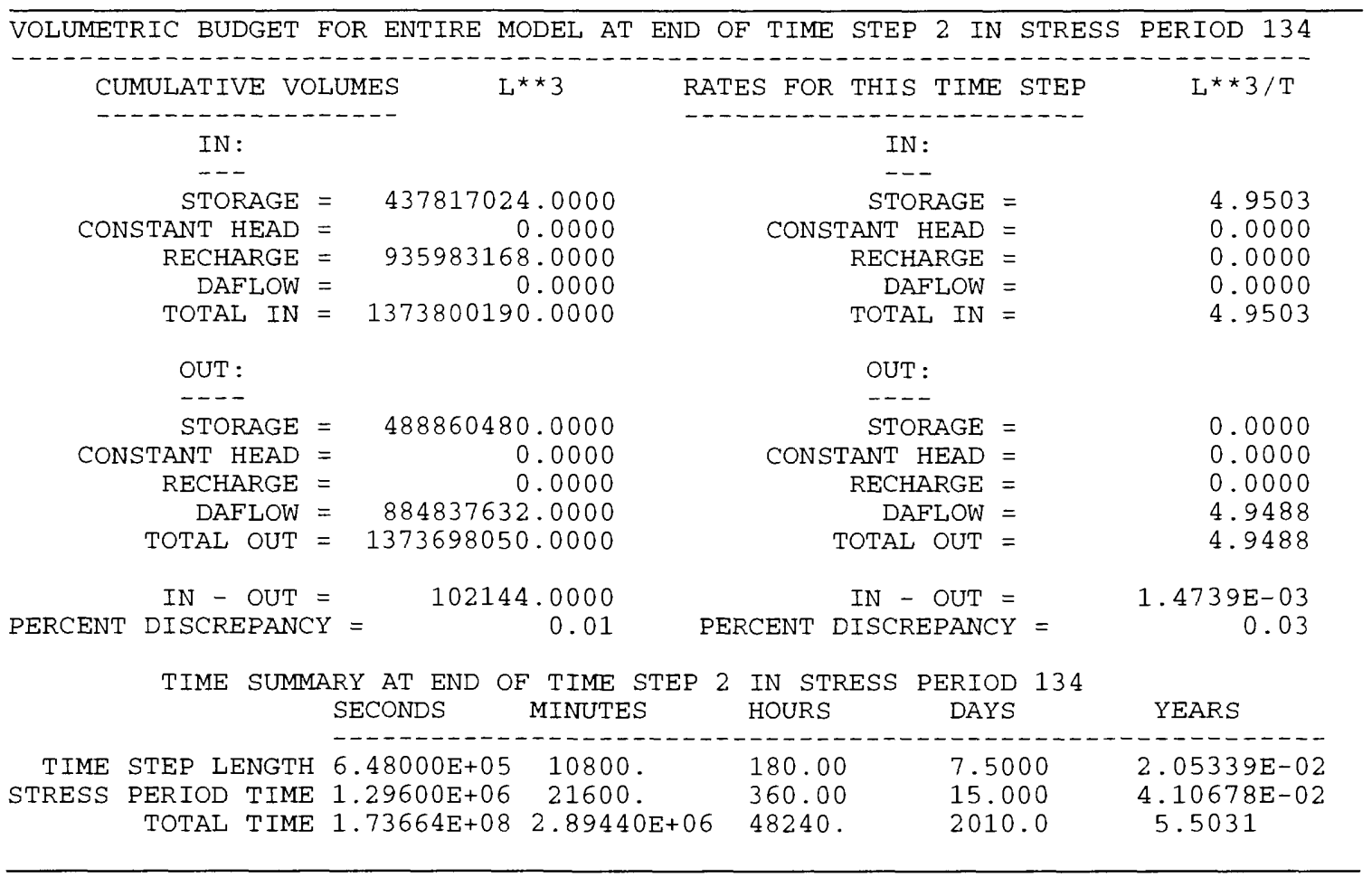

Figure 12 (Continued). Selected output of the Modular Finite-Difference Ground-Water Flow model results at stress period 134, for example 1.

The simulated streamflow at node 14 as a function of time in comparison to the analytic values is shown in figure 13. The simulated flows average $0.007 \mathrm{ft}^{3} / \mathrm{s}$ higher than the analytic values, with an RMS error of $0.074 \mathrm{ft}^{3} / \mathrm{s}$. The maximum positive error in the simulated flow of $+0.169 \mathrm{ft}^{3} / \mathrm{s}$ occurred at day 60 and was 1.1 percent of the instantaneous flow. The maximum negative error of $-0.090 \mathrm{ft}^{3} / \mathrm{s}$ occurred at day 150 and represented 0.5 percent of the instantaneous flow. Note that the computed flows have a scalloped appearance. Recharge was assumed constant during each 15 day stress period. The flow changes rapidly at the beginning of the stress period, but changes much more slowly near the end of the stress period.

An assumption in the analytical solution is that a change in seepage anywhere along the stream results in an instantaneous change in streamflow at all downstream points. DAFLOW, however, will simulate the lag time between when water enters at one point and travels downstream to another point. The time lag is equal to the distance between the nodes divided by the wave celerity. The wave celerity can be computed from equation 11 and varies from $2.5 \mathrm{ft} / \mathrm{s}$ at $10 \mathrm{ft}^{3} / \mathrm{s}$ to $5.0 \mathrm{ft} / \mathrm{s}$ at $20 \mathrm{ft}^{3} / \mathrm{s}$. So the lag time for a change in inflow at node 2 to affect the fow at node 14 varies from about 0.7 to 1.4 hours. This lag is not significant in comparison to the time step of 180 hours used in DAFLOW. So it can be concluded that the two-dimensional system simulated by MODFLOW/DAFLOW behaves the same as the one-dimensional analytical counterpart at this time scale. 


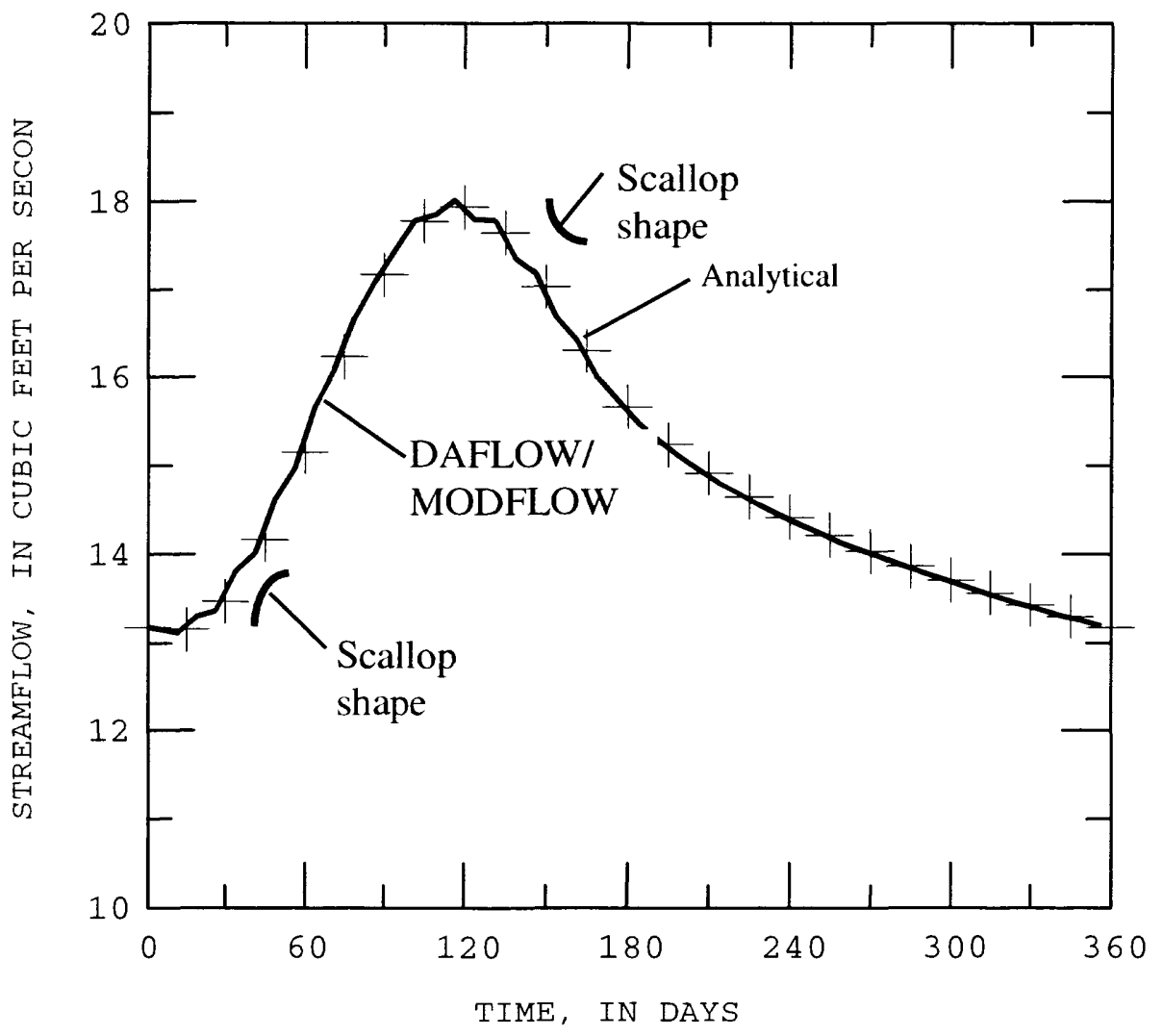

Figure 13. Simulated streamflow at node 14 and the analytical solution.

The simulated time variation of the head in a well that is assumed to be in row 7 , colurn 10 , with the variation computed by the analytical solution is shown in figure 14. The mean difference between the analytical and simulated results is $0.006 \mathrm{ft}$ with a standard deviation of $0.026 \mathrm{ft}$. The maximum errors are $+0.081 \mathrm{ft}$ (analytical larger than simulated) on day 45 , and $-0.029 \mathrm{ft}$ on day 360. 


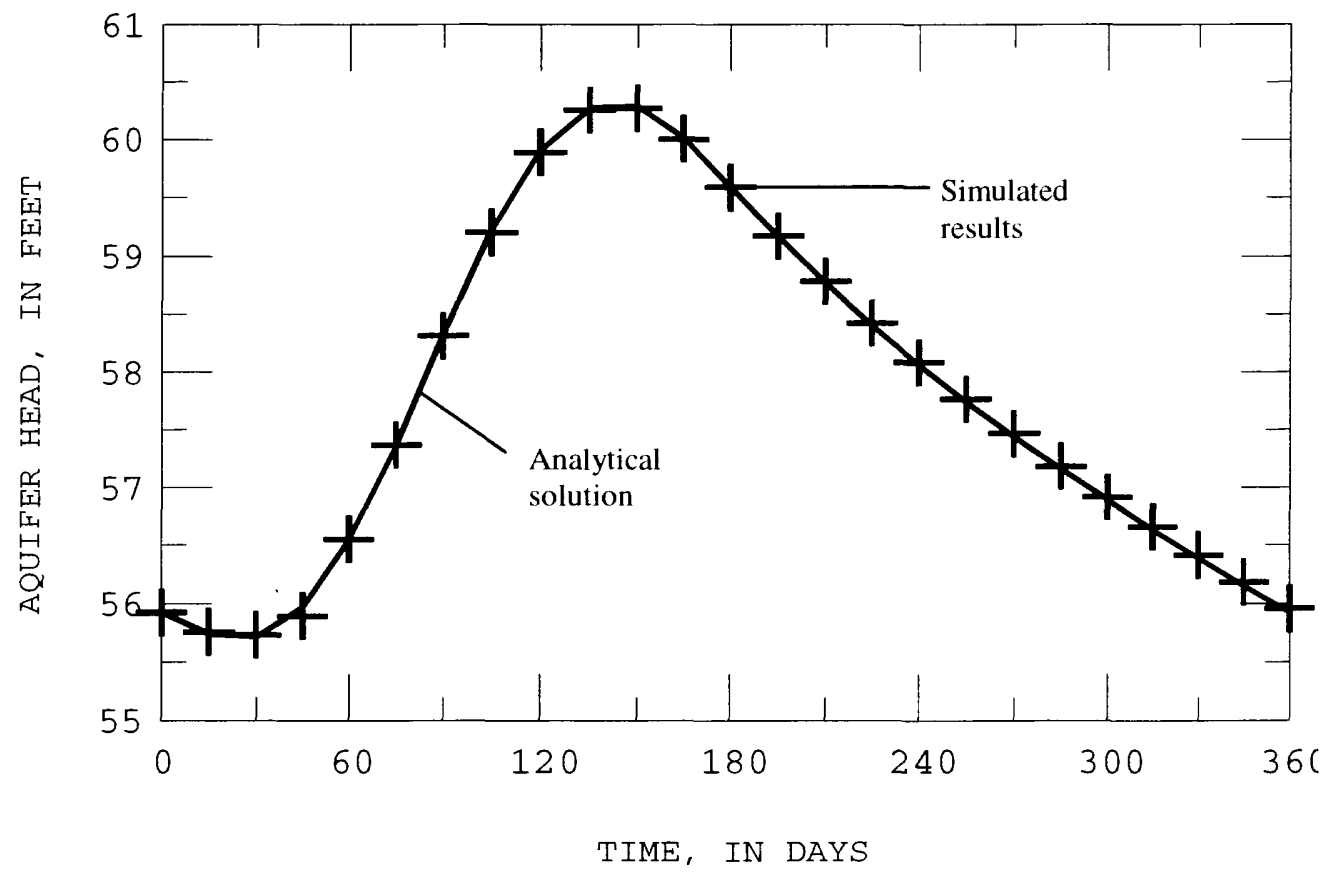

Figure 14. The simulated and analytical variation of water level in a well located in row 7 , column 10 of figure 8 .

Profiles of the aquifer head in row 7 on the right side of the stream on day 177, near the end of the recharge period are shown in figure 15 . The initial profile, on day zero is also shown to give an indication of the approximate maximum variation of head in the aquifer. Profiles in all rows of the aquifer are identical because of the assumptions of the stream level being constant, uniform recharge, and no transport across the boundaries. All rows in the simulated results were identical to within at least $0.01 \mathrm{ft}$. This further confirms that the system is behaving as the onedimensional analytical model. The mean error of the simulated points is $0.007 \mathrm{ft}$ and the RMS error is $0.026 \mathrm{ft}$. 


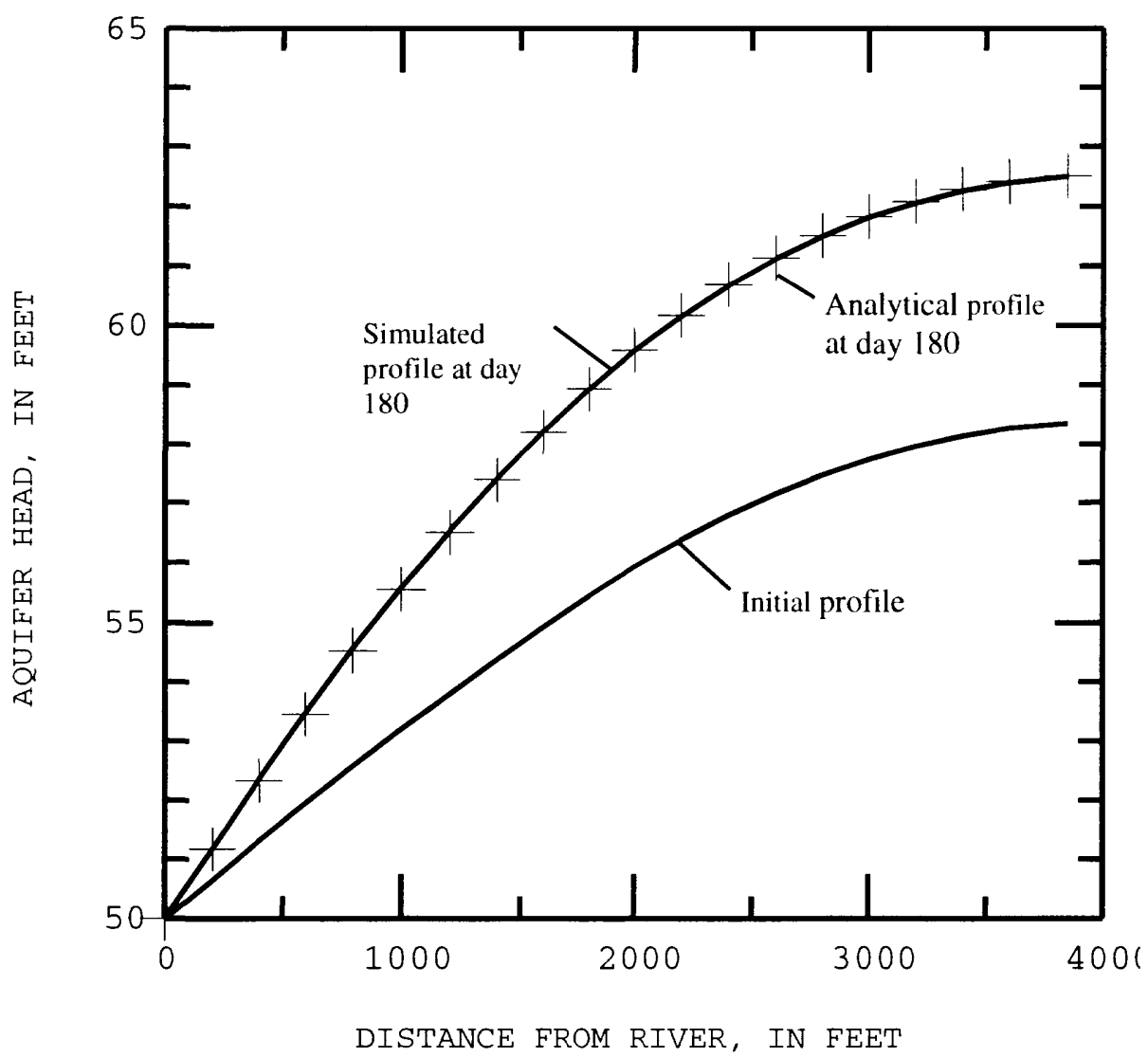

Figure 15. Aquifer-head profiles simulated by the Diffusion Analogy Flow model linked to the Modular Finite-Difference Ground-Water Flow model and the analytical solution.

The small differences in the assumed discharge distribution between the analytical solution and the simulation results, support the conclusion that the linked MODFLOW/DAFLOW simulation model duplicated the analytical solution.

\section{Example 2, Bank storage due to flood stages, comparison with ar analytical solution}

The second example compares simulated leakage to an aquifer resulting from a flood w'ave with the analytical solution developed by Cooper and Rorabaugh (1963). The example uses the same model grid, stream, as well as streambed and aquifer characteristics as used in the fir:t example (see figure 8). Assumptions used in both the analytical solution and the model simulation are also the same as those listed for example 1 except for assumptions 9 and 10 . These are replaced with the following:

1. The recharge to the aquifer is only from the stream as the stream stage increases with time.

2. The discharge from the aquifer is also only to the stream as the stream stage decreases with time. 
The analytical solution does not specify a discharge but assumes the stream stage varies during the first 30 days according to the equation:

$$
\text { stage }=\mathrm{H}_{0}+\mathrm{H}_{1} \sin ((\text { day }-7.5) 2 \pi / 30),
$$

in which $\mathrm{H}_{0}$ and $\mathrm{H}_{1}$ are constants. It assumes the stage is constant at $\mathrm{H}_{0}-\mathrm{H}_{1}$ after that. The stream stage is the driving force for the leakage. Following Prudic (1989), it is assumed that the stage and stream depth are the same and that $\mathrm{H}_{0}=10 \mathrm{ft}$ and $\mathrm{H}_{1}=2 \mathrm{ft}$. It is also assumed that the stream inflow varies from a minimum of $2,000 \mathrm{ft}^{3} / \mathrm{s}$ to a maximum of $4,000 \mathrm{ft}^{3} / \mathrm{s}$. The DAFLOW model does not allow the width to remain precisely constant $(\mathrm{W} 2=0)$ so the width is assumet to be $100.00 \mathrm{ft}$ at $3,000 \mathrm{ft}^{3} / \mathrm{s}$ and to vary slightly (W2 $=0.01$ ) from $99.59 \mathrm{ft}$ at $2,000 \mathrm{ft}^{3} / \mathrm{s}$ to 100.28 $\mathrm{ft}$ at $4,000 \mathrm{ft}^{3} / \mathrm{s}$. To match the assumed stages, the area must vary from $8 \times 99.59=796.71 \mathrm{ft}^{2}$ to $12 \times 100.28=1203.37 \mathrm{ft}^{2}$ as the flow varies from 2,000 to $4,000 \mathrm{ft}^{3} / \mathrm{s}$. The hydraulic-geometry parameters that provide these areas can be computed from equation 11 as $\mathrm{Al}=8.655$ and $\mathrm{A} 2=$ 0.595 . Knowing the hydraulic-geometry parameters, the discharge for any depth can be comp'ted as:

$$
Q=(D \cdot W 1 / A 1)^{\frac{1}{A 2-A 1}},
$$

where $\mathrm{Q}=$ discharge, $\mathrm{D}=$ depth. The assumed inflow at node 1 for the numerical model is as shown in figure 16. DAFLOW was run using a one-day time step, so the inflows for any day are based on the depth occurring at the midpoint of the day. Because discharge is not linearly relcted to depth, the inflows are not distributed in a sinusoidal pattern. The inflow to the numerical model is represented by a series of histograms of width equal to one day, whereas the flow in the analytical model is a smooth curve. 


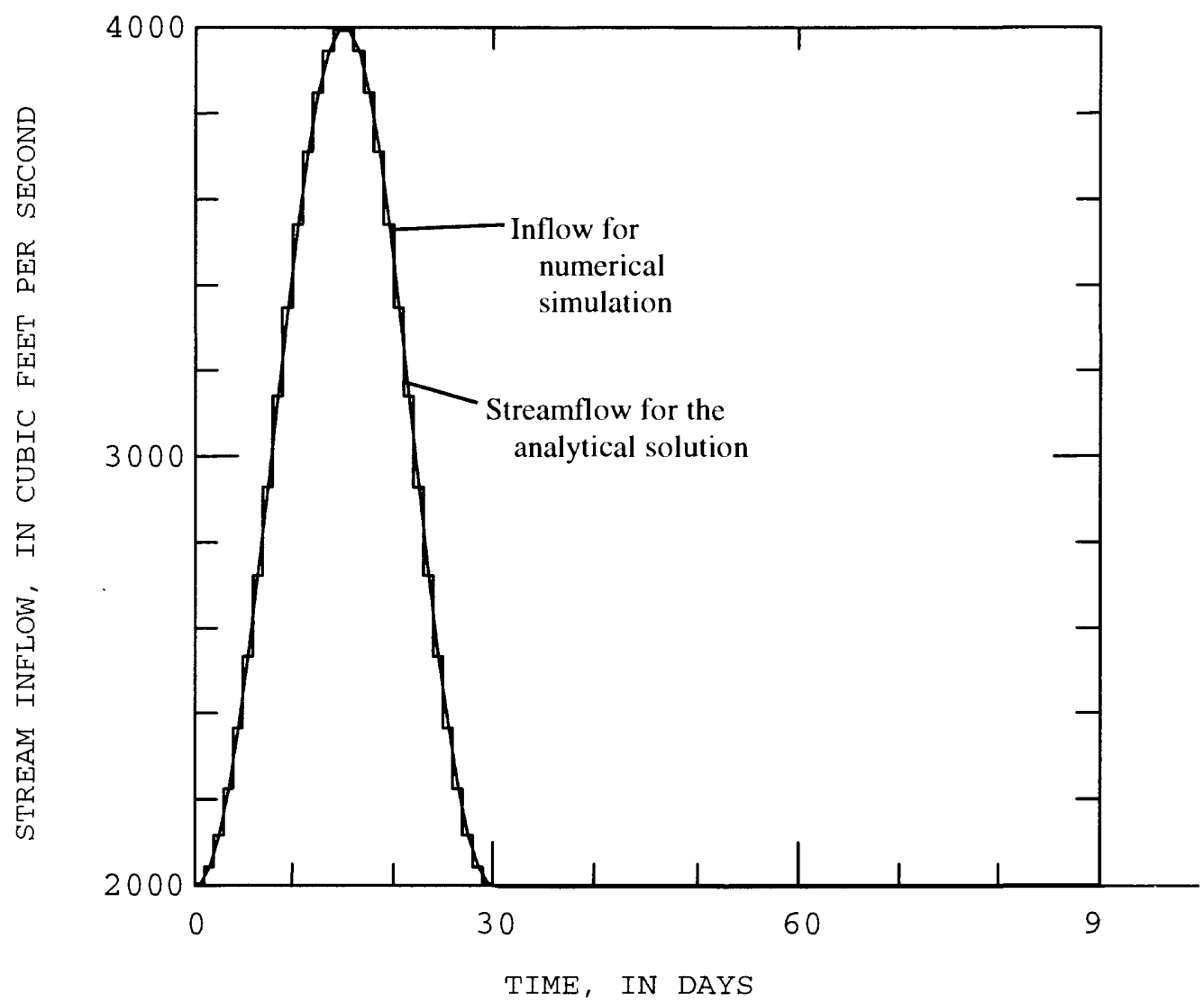

Figure 16. Distribution of streamflow for a 30-day flood event used in example 2.

The analytical model is one-dimensional so it solves only one row in the numerical model. For the results of the two models to be comparable the stream depth in all rows of the numerical model must be the same. To achieve this, the model was first run with constant hydraulicgeometry coefficients as shown for subreach 1 in figure 17, which is a listing of the input file, flow.in. The streamflow in the numerical model varies from node to node as leakage is withdrawn or added to the flow. After the model was run with constant hydraulic-geometry parameters, the peak flow in each subreach was determined, and the parameters were adjusted such that the water depth varied between 8 and $12 \mathrm{ft}$ as the flow varied from $2,000 \mathrm{ft}^{3} / \mathrm{s}$ to the peak flow in the subreach. The final coefficients are shown in figure 17. 


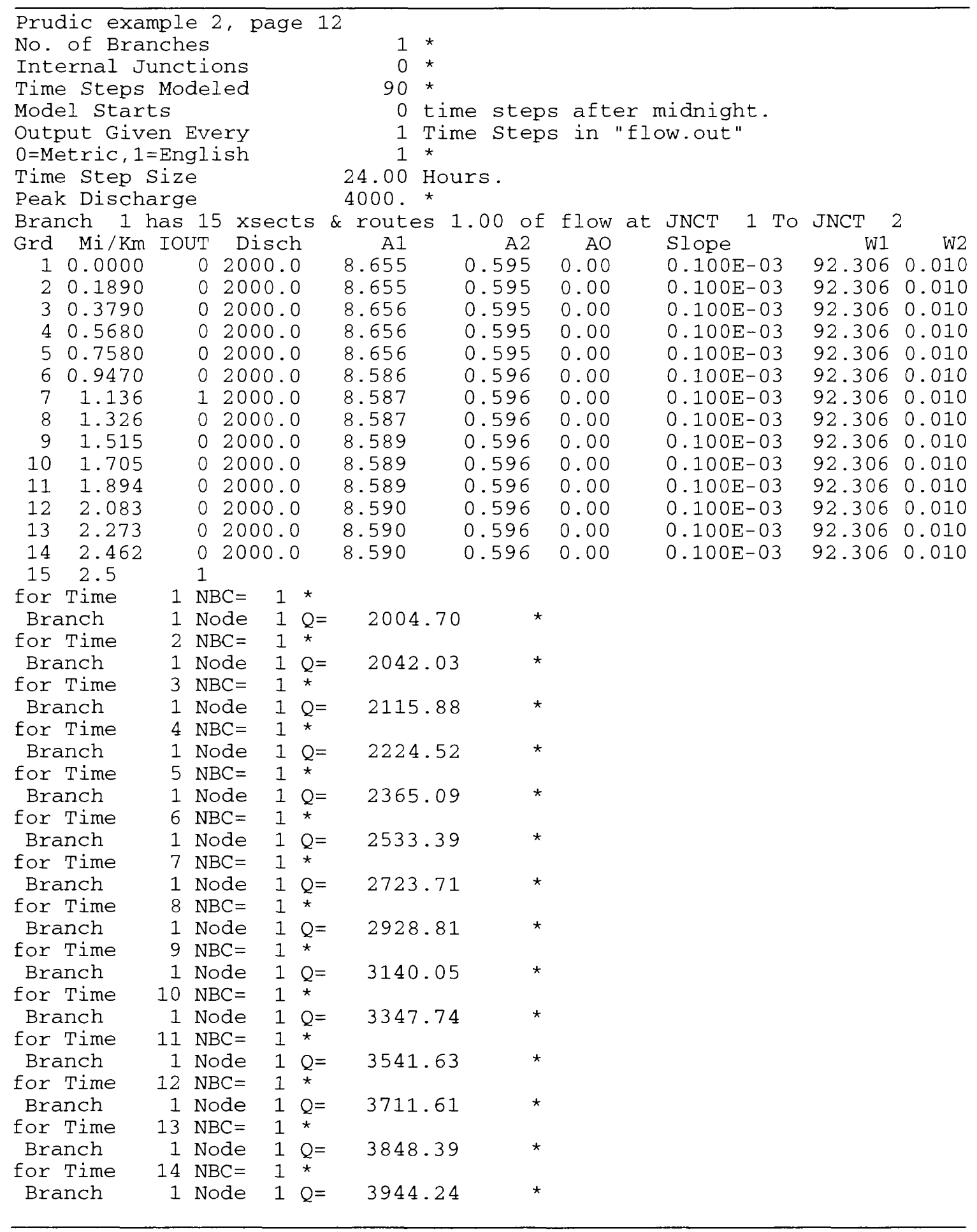

Figure 17. Input file, flow.in, for example 2. 


\begin{tabular}{|c|c|c|c|c|c|c|}
\hline for Time & 15 & $\mathrm{NBC}=$ & 1 & * & & \\
\hline Branch & 1 & Node & 1 & $Q=$ & 3993.61 & * \\
\hline for Time & 16 & $\mathrm{NBC}=$ & 1 & $\star$ & & \\
\hline Branch & 1 & Node & 1 & $Q=$ & 3993.61 & * \\
\hline for Time & 17 & $\mathrm{NBC}=$ & 1 & $\star$ & & \\
\hline Branch & 1 & Node & 1 & $Q=$ & 3944.24 & * \\
\hline for Time & 18 & $\mathrm{NBC}=$ & 1 & $\star$ & & \\
\hline Branch & 1 & Node & 18 & $Q=$ & 3848.39 & $\star$ \\
\hline for Time & 19 & $\mathrm{NBC}=$ & 1 & * & & \\
\hline Branch & 1 & Node & 1 & $\mathrm{Q}=$ & 3711.61 & * \\
\hline for Time & 20 & $\mathrm{NBC}=$ & 1 & * & & \\
\hline Branch & 1 & Node & 1 & $Q=$ & 3541.63 & $\star$ \\
\hline for Time & 21 & $\mathrm{NBC}=$ & 1 & * & & \\
\hline Branch & 1 & Node & 1 & $Q=$ & 3347.74 & $\star$ \\
\hline for Time & 22 & $\mathrm{NBC}=$ & 1 & $\star$ & & \\
\hline Branch & 1 & Node & 1 & $\mathrm{Q}=$ & 3140.05 & * \\
\hline for Time & 23 & $\mathrm{NBC}=$ & 1 & * & & \\
\hline Branch & 1 & Node & 1 & $Q=$ & 2928.81 & $\star$ \\
\hline for Time & 24 & $\mathrm{NBC}=$ & 1 & $\star$ & & \\
\hline Branch & 1 & Node & 1 & $Q=$ & 2723.71 & $\star$ \\
\hline for Time & 25 & $\mathrm{NBC}=$ & 1 & * & & \\
\hline Branch & 1 & Node & 1 & $\mathrm{Q}=$ & 2533.39 & * \\
\hline for Time & 26 & $\mathrm{NBC}=$ & 1 & * & & \\
\hline Branch & 1 & Node & 1 & $\mathrm{Q}=$ & 2365.09 & * \\
\hline for Time & 27 & $\mathrm{NBC}=$ & 1 & $\star$ & & \\
\hline Branch & 1 & Node & 1 & $Q=$ & 2224.52 & $\star$ \\
\hline for Time & 28 & $\mathrm{NBC}=$ & 1 & $\star$ & & \\
\hline Branch & 1 & Node & 1 & $Q=$ & 2115.88 & * \\
\hline for Time & 29 & $\mathrm{NBC}=$ & 1 & $\star$ & & \\
\hline Branch & 1 & Node & 1 & $Q=$ & 2042.03 & * \\
\hline for Time & 30 & $\mathrm{NBC}=$ & 1 & $\star$ & & \\
\hline Branch & 1 & Node & 1 & $Q=$ & 2004.70 & $\star$ \\
\hline for Time & 31 & $\mathrm{NBC}=$ & 1 & $\star$ & & \\
\hline Branch & 1 & Node & 1 & $Q=$ & 2000.00 & $\star$ \\
\hline for Time & 32 & $\mathrm{NBC}=$ & 0 & & & \\
\hline & & & & & & \\
\hline & & & & & & \\
\hline for Time & 90 & $\mathrm{NBC}=$ & 0 & & & \\
\hline
\end{tabular}

Figure 17 (continued). Input file, flow.in, for example 2.

The other input file for DAFLOW, the DAFG file, used for example 2 is the same as the one shown in figure 11, except that the arbitrary bed elevation is changed from 46.00 to 40.00 . All additional input files for MODFLOW are shown in Appendix $C$ for example 2.

Selected output of MODFLOW/DAFLOW is shown in figure 18 for stress period 15, the peak inflow period. Heads in only one row are shown, but the heads in all other rows were within $0.002 \mathrm{ft}$, indicating that the system is essentially one-dimensional. As seen from the volumotric budget for the entire model, the leakage from the stream to the aquifer averages $7.5539 \mathrm{ft}^{3} / \mathrm{s}$ for this stress period. 


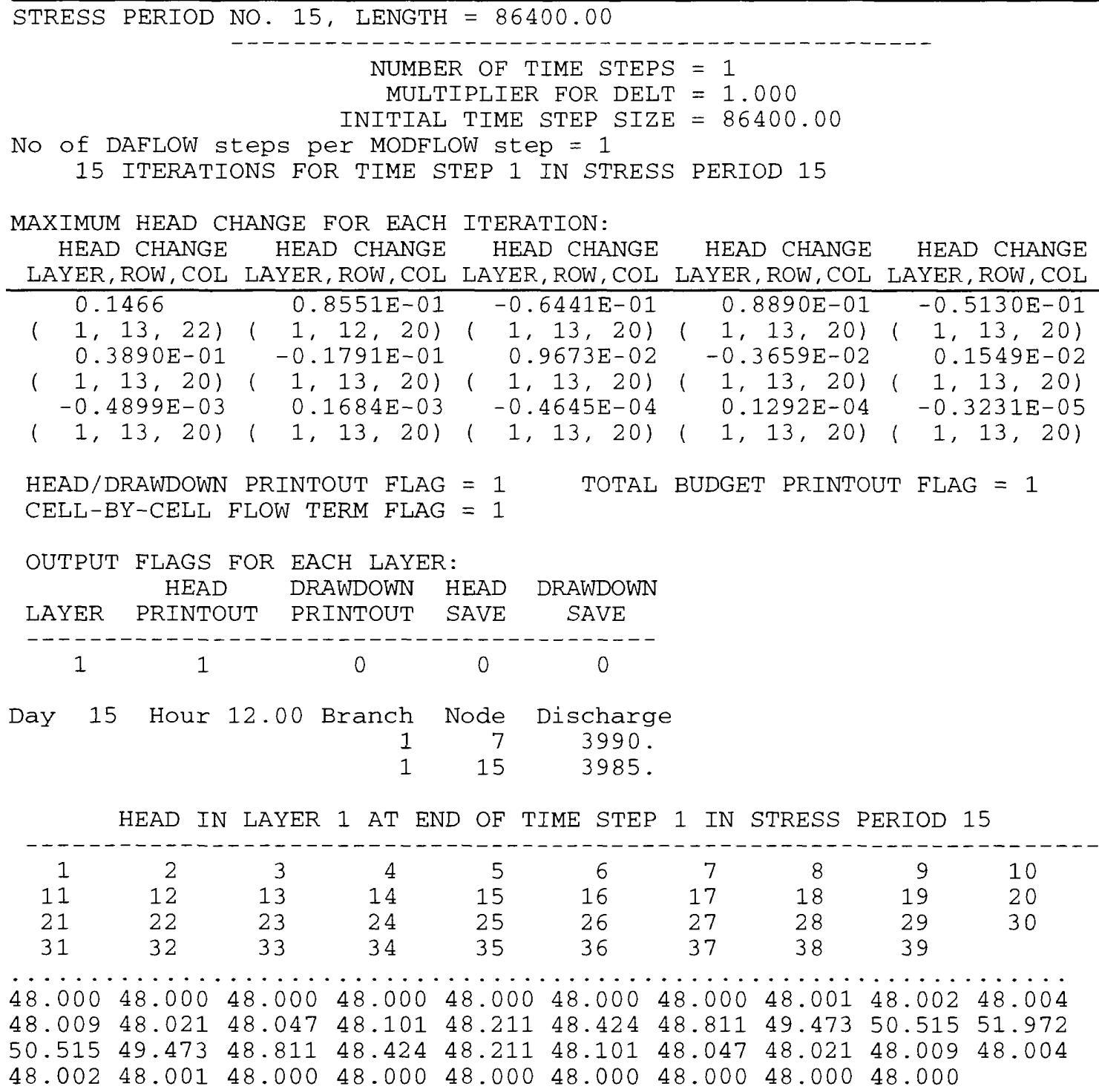

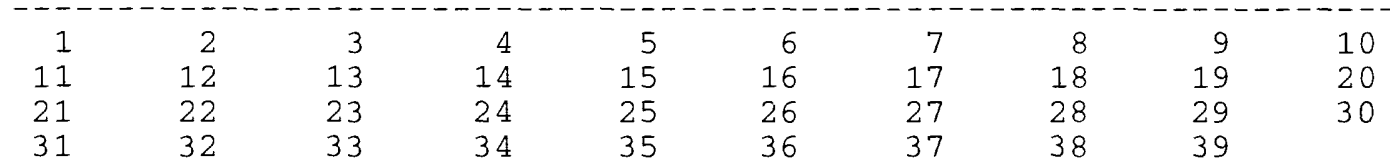

Figure 18. Selected output of the Modular Finite-Difference Ground-Water Flow model at stress period 15, for example 2. 


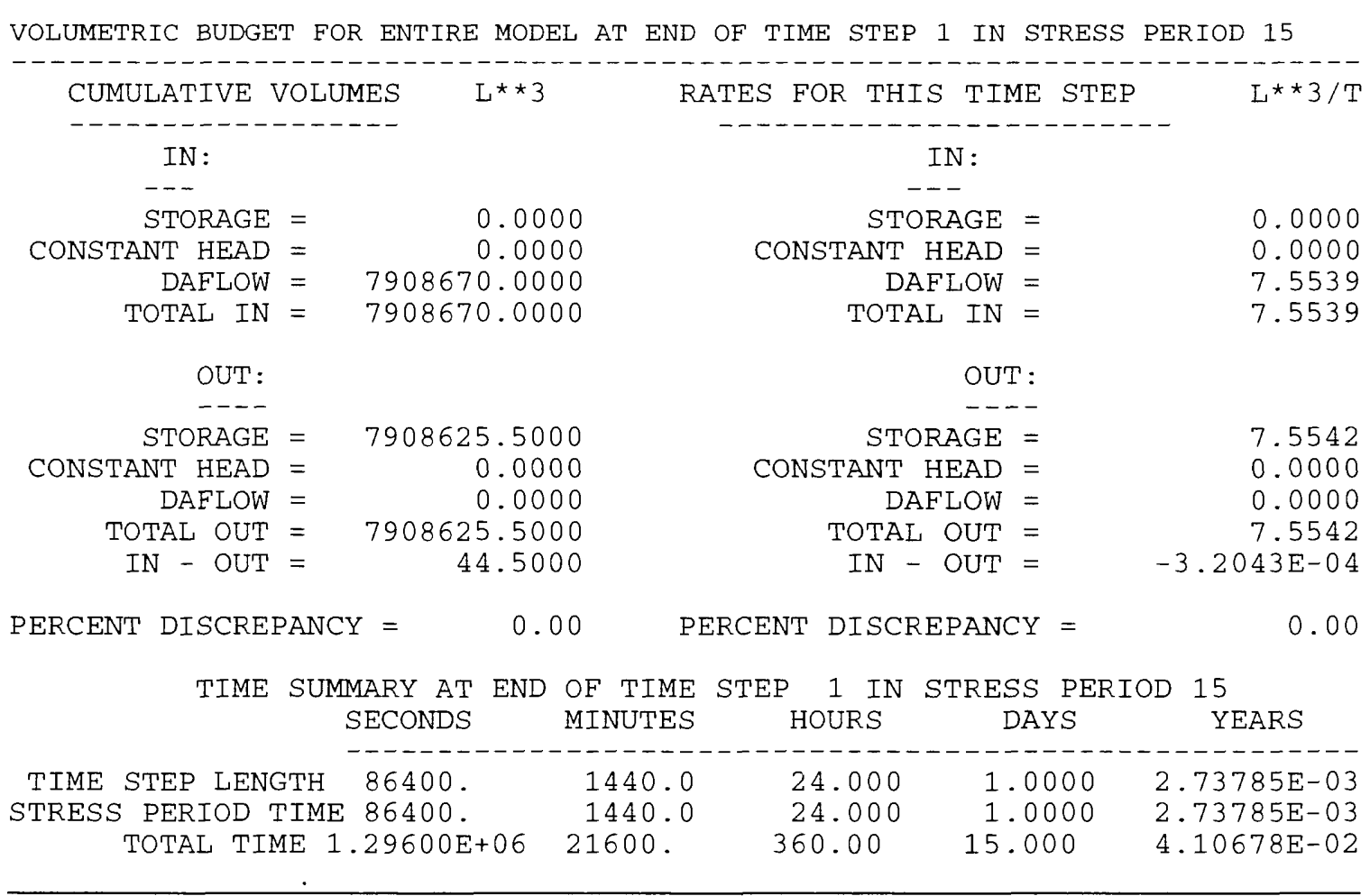

Figure 18 (continued). Selected output of the Modular Finite-Difference Ground-Water Flow model at stress period 15, for example 2.

The simulated ground-water exchange between the stream and the aquifer and the analytical value are shown in figure 19. The mean and RMS differences on figure 19 are -0.0044 and $0.0102 \mathrm{ft}^{3} / \mathrm{s}$ respectively. The close agreement in the computed leakage values again supports the accuracy of the linked MODFLOW and DAFLOW models. 


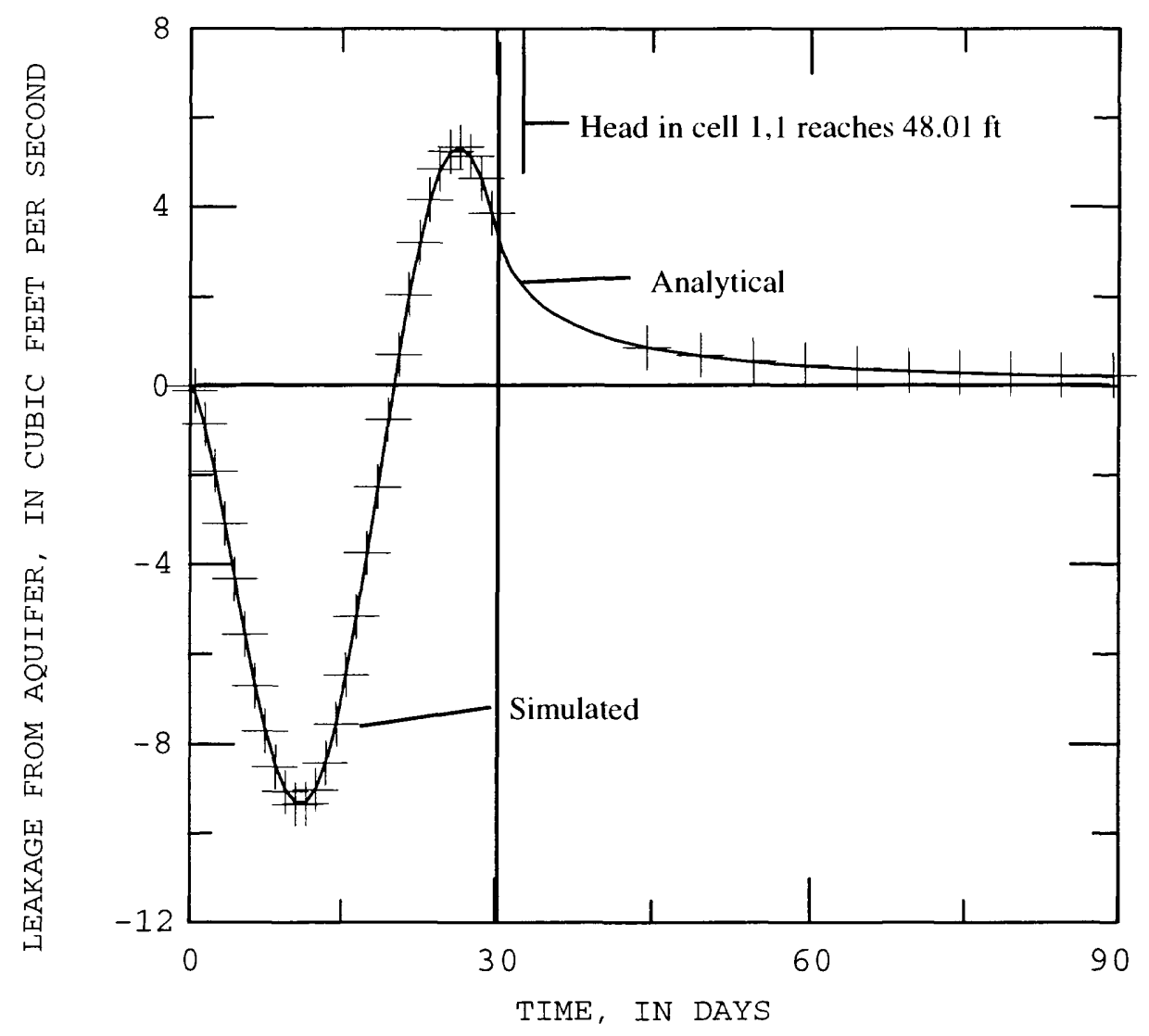

Figure 19. Simulated and analytical flow between the aquifer and the stream for example 2.

For the hydraulic-geometry parameters assumed in this example, the wave celerity varies from 4.1 to $5.4 \mathrm{ft} / \mathrm{s}$ as the discharge varies from 2,000 to $4,000 \mathrm{ft}^{3} / \mathrm{s}$. Thus, the lag time for a response at node 2 to influence the flow at node 14 varies from about 0.6 to 0.8 hours. In comparison to the 24-hour time step, this lag is expected to have minimal effect on the results. The analytical solution is for an aquifer of infinite width, whereas the numerical solution assumes a finite width. It is sometime after day 30 that the head in columns 1 and 39 change from the initial values by as much as $0.01 \mathrm{ft}$. The maximum head in these cells of 48.058 occurs at the end of the simulation. The effect of the walls on the leakage probably would be minimal for times less than 90 days.

\section{Example 3, Bank storage under unsteady flow}

The third example illustrates the effect of bank storage resulting from unsteady flow. The example uses the grid and surface-water network of the third example of Swain \& Wexler (1993). This example also illustrates the use of the model with a branched surface-water flow system.

The hypothetical aquifer stretches $20,500 \mathrm{ft}$ from north to south and $10,500 \mathrm{ft}$ from east to west. A schematic of the aquifer and surface-water grid is shown on figure 20 . The aquifer has 
impermeable boundaries on the east and west, a specified-flow northern boundary, and a cc istant head southern boundary. The aquifer has a transmisivity of $0.116 \mathrm{ft}^{2} / \mathrm{s}$, a storage coefficient of 0.20 , and a constant flow across the northern boundary of $126,000 \mathrm{ft}^{3} / \mathrm{day}\left(1.46 \mathrm{ft}^{3} / \mathrm{s}\right)$. By using 21 columns and 41 rows, the MODFLOW cells are $500 \mathrm{ft}$ square. The initial aquifer head is assumed to vary uniformly from $25.6 \mathrm{ft}$ at the northern boundary to $1.00 \mathrm{ft}$ at the southern boundary giving, a slope of $0.0012(6.34 \mathrm{ft} / \mathrm{mi})$. The ground-water model is run for 32,30 -minute time steps.

The surface-water system consists of minor channels entering the aquifer at the northeast and northwest corners and joining to form a single channel at a distance of 5,250 feet south of the northern boundary, in the center of cell 11,11. This single channel flows straight south down the center of the aquifer to the southern boundary. The channel flows are initially zero, and a runoff hydrograph enters each minor channel starting 30 minutes into the run. 


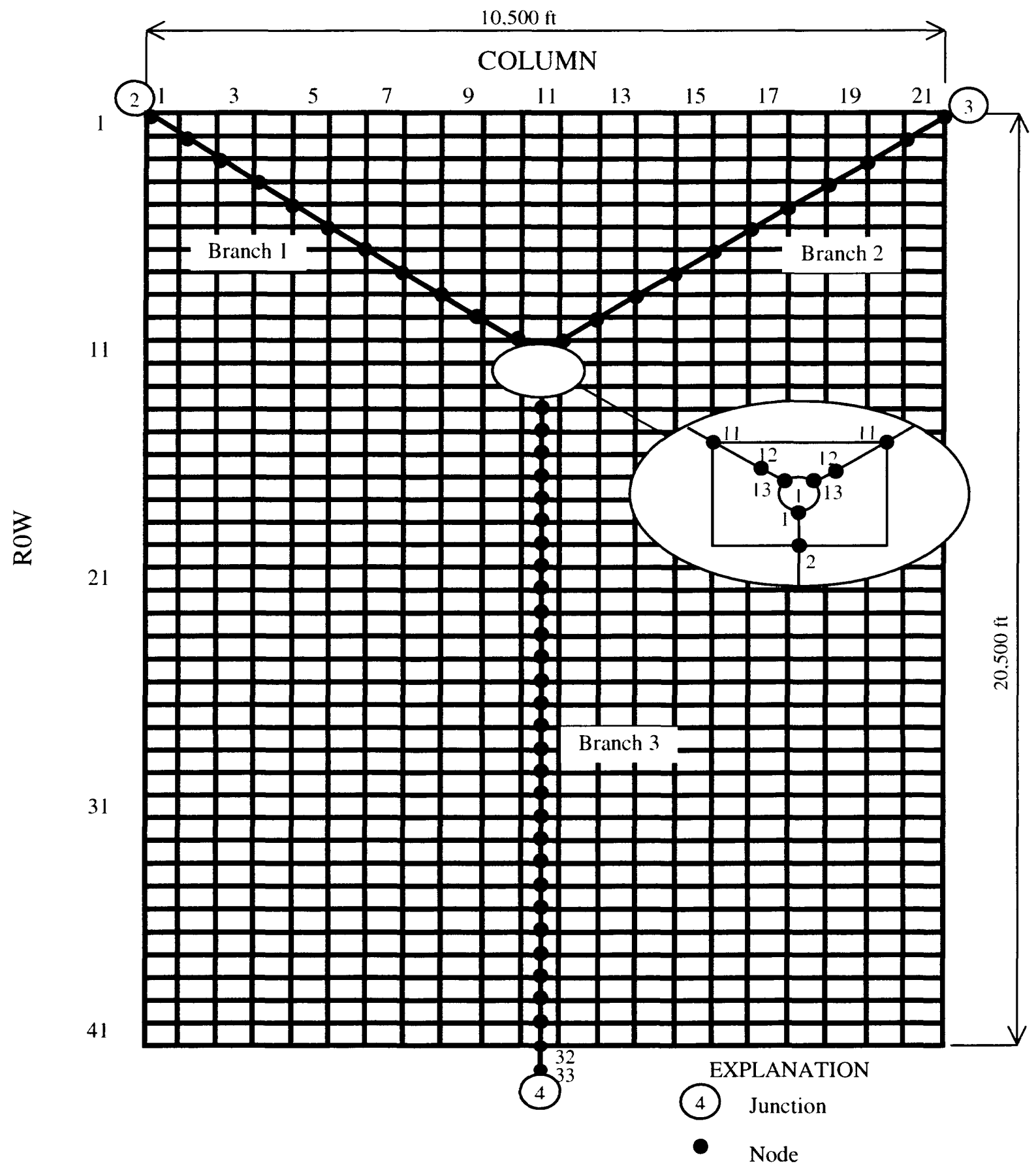

Figure 20. Ground-water model grid of example 3 with surface-water model grid superimposed. 
It is assumed that the minor and main channels are typical of streams in Missouri with drainage areas of 10 and $30 \mathrm{sq} \mathrm{mi,} \mathrm{respectively.} \mathrm{It} \mathrm{is} \mathrm{also} \mathrm{assumed} \mathrm{that} \mathrm{the} \mathrm{bed} \mathrm{elevation} \mathrm{of} \mathrm{all}$ channels are the same as initial surface elevation of the aquifer, so the slope of the upstream channels is 0.000848 and the slope of the downstream channel is 0.0012 . According to Jennings and others (1994, p.99), a runoff event with an expected return period of 2 years should have a peak flow of about $463 \mathrm{ft}^{3} / \mathrm{s}$ for streams with the drainage area and slope of the upstream channels. Likewise, the time of concentration can be expected to be about 2.7 hours (Jennings and others, 1994, p.196). Based on the peak flow and lag time, the inflow hydrograph was determined for the upstream channels by using the dimensionless hydrograph presented by Inman (1987, p. 7).

The next task was to select hydraulic characteristics for the channels. Hydraulic-geometry exponents of area and width were selected as 0.66 and 0.26 , respectively, which are typical of values observed for a wide range of streams (Jobson, 1989, p. 7). Many studies have shown that channel widths are correlated with the channel-forming discharge, which in turn, is often approximated as the peak flow with a return period of 2 years. Combining the work of Osterkamp (1980), Kilpatrick and Barnes (1964) and Wolman and Leopold (1957), an empirical expression for the hydraulic-geometry coefficient for width can be developed as:

$$
W 1=3.34 Q^{0.56-W 2} \text {, }
$$

in which $\mathrm{W} 1$ = hydraulic-geometry coefficient for width using the English system of units (ft, $\left.\mathrm{ft}^{3} / \mathrm{s}\right), \mathrm{Q}_{\mathrm{c}}=$ channel forming discharge, in $\mathrm{ft}^{3} / \mathrm{s}$, and $\mathrm{W} 2=$ the hydraulic-geometry exponent for width (see equation 12). Assuming channel forming discharges of 463 and $1,000 \mathrm{ft}^{3} / \mathrm{s}$, the ralues of $\mathrm{W} 1$ are 21.1 and 26.6, respectively, for the upper and lower channels.

It was assumed that the upper and lower channels have a Mannings $n$ of 0.035 at a flow of $250 \mathrm{ft}^{3} / \mathrm{s}$ and $500 \mathrm{ft}^{3} / \mathrm{s}$ respectively. Assuming A0 to be zero (not a pool and riffle stream), equation 11 yields values of Al to be 3.79 and 3.87, respectively, for the upstream and downstream channels. As the discharge increases from 50 to $450 \mathrm{ft}^{3} / \mathrm{s}$ in the upstream channels, the velocity, width, and depth increase from 1.0 to $2.1 \mathrm{ft} / \mathrm{s}, 58$ to $103 \mathrm{ft}, 0.86$ to $2.1 \mathrm{ft}$, respectively. The width depth ratio decreases from 67 to 50 . Likewise, as the discharge in the lower channel increases from 100 to $1,000 \mathrm{ft}^{3} / \mathrm{s}$, the velocity, width, and depth increase from 1.2 to $2.3 \mathrm{ft} / \mathrm{s}, 88$ to $160 \mathrm{ft}$, and 0.9 to $2.3 \mathrm{ft}$, respectively. The width depth ratio decreases from 96 to 69 .

The input file flow.in (example3.inf) used for example 3 is shown in figure 21 . Notice the model has 3 branches, and 1 internal junction (that must be numbered 1). The flow model is run for 64 time steps, each 0.25 hours long, ( 2 for each MODFLOW time step). The output is written every time step. Because the MODFLOW model is run for 32 time steps, the surface-water output is written twice for each MODFLOW time step. The peak discharge is set at $1,000 \mathrm{ft}^{3} / \mathrm{s}$, so any flow of less than $0.01 \mathrm{ft}^{3} / \mathrm{s}$ will be ignored. Branch 1 has 13 nodes (xsects) with the first being at the northern boundary of the aquifer and node 12 being at mile $1.406(7,423.7 \mathrm{ft}$ from the northern boundary and $0.9 \mathrm{ft}$ from the center of cell 11,11). Subreach 11, which is upstream of node 12 , is the last subreach for branch 1 that interacts with the aquifer, so node 13 is located only a short distance downstream. The slopes of branch $1(0.000848)$ and branch $3(0.0012)$ yield the same north-south fall as the initial aquifer head. 


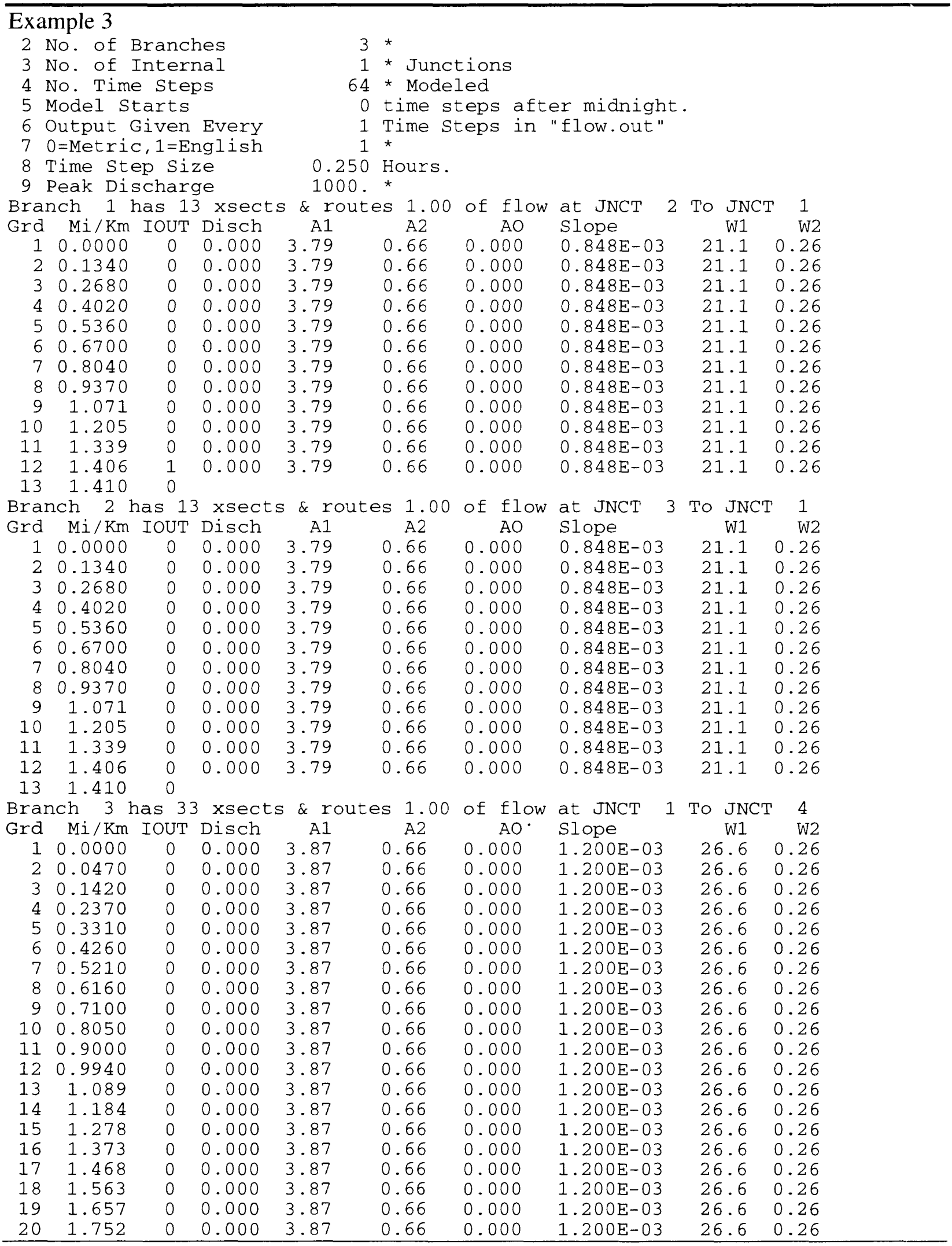

Figure 21. Input file, flow.in, for example 3. 


\begin{tabular}{|c|c|c|c|c|c|c|c|c|c|}
\hline 1.847 & & 0.0 & & 3.87 & 0.66 & 0.000 & $1.200 \mathrm{E}-03$ & 26.6 & 0.26 \\
\hline 1.941 & & 0.0 & & 3.87 & 0.66 & 0.000 & $1.200 \mathrm{E}-03$ & 26.6 & 0.26 \\
\hline $23 \quad 2.036$ & & 0.0 & & 3.87 & 0.66 & 0.000 & $1.200 \mathrm{E}-03$ & 26.6 & 0.26 \\
\hline 2.131 & & 0.0 & & 3.87 & 0.66 & 0.000 & $1.200 \mathrm{E}-03$ & 26.6 & 0.26 \\
\hline 2.225 & & 0.0 & & 3.87 & 0.66 & 0.000 & $1.200 \mathrm{E}-03$ & 26.6 & 0.26 \\
\hline $26 \quad 2.320$ & & 0.0 & & 3.87 & 0.66 & 0.000 & $1.200 \mathrm{E}-03$ & 26.6 & 0.26 \\
\hline $27 \quad 2.415$ & & 0.0 & & 3.87 & 0.66 & 0.000 & $1.200 E-03$ & 26.6 & 0.26 \\
\hline $28 \quad 2.509$ & & 0.0 & & 3.87 & 0.66 & 0.000 & $1.200 \mathrm{E}-03$ & 26.6 & 0.26 \\
\hline $29 \quad 2.604$ & & 0.0 & & 3.87 & 0.66 & 0.000 & $1.200 \mathrm{E}-03$ & 26.6 & 0.26 \\
\hline $30 \quad 2.699$ & & 0.0 & & 3.87 & 0.66 & 0.000 & $1.200 \mathrm{E}-03$ & 26.6 & 0.26 \\
\hline $31 \quad 2.794$ & & 0.0 & & 3.87 & 0.66 & 0.000 & $1.200 \mathrm{E}-03$ & 26.6 & 0.26 \\
\hline $32 \quad 2.888$ & & 0.0 & & 3.87 & 0.66 & 0.000 & $1.200 \mathrm{E}-03$ & 26.6 & 0.26 \\
\hline $33 \quad 3.000$ & & 0 & & & & & & & \\
\hline for Time & 1 & $\mathrm{NBC}=$ & 0 & * & & & & & \\
\hline for Time & 2 & $\mathrm{NBC}=$ & 0 & * & & & & & \\
\hline for Time & 3 & $\mathrm{NBC}=$ & 2 & * & & & & & \\
\hline Branch & 1 & Node & 1 & $Q=$ & 10.300 & * & & & \\
\hline Branch & 2 & Node & 1 & $\bar{Q}=$ & 10.300 & * & & & \\
\hline for Time & 4 & $\mathrm{NBC}=$ & 2 & $\star$ & & & & & \\
\hline Branch & 1 & Node & 1 & $Q=$ & 30.890 & * & & & \\
\hline Branch & 2 & Node & 1 & $\mathrm{Q}=$ & 30.890 & * & & & \\
\hline for Time & 5 & $\mathrm{NBC}=$ & 2 & $\star$ & & & & & \\
\hline Branch & 1 & Node & 1 & $Q=$ & 51.480 & * & & & \\
\hline Branch & 2 & Node & 1 & $\hat{Q}=$ & 51.480 & * & & & \\
\hline for Time & 6 & $\mathrm{NBC}=$ & 2 & * & & & & & \\
\hline Branch & 1 & Node & 1 & $Q=$ & 85.220 & * & & & \\
\hline Branch & 2 & Node & 1 & $Q=$ & 85.220 & * & & & \\
\hline for Time & 7 & $\mathrm{NBC}=$ & 2 & * & & & & & \\
\hline Branch & 1 & Node & 1 & $Q=$ & 131.20 & * & & & \\
\hline Branch & 2 & Node & 1 & $\mathrm{Q}=$ & 131.20 & * & & & \\
\hline for Time & 8 & $\mathrm{NBC}=$ & 2 & * & & & & & \\
\hline Branch & 1 & Node & 1 & $Q=$ & 192.90 & * & & & \\
\hline Branch & 2 & Node & 1 & $\bar{Q}=$ & 192.90 & * & & & \\
\hline for Time & 9 & $\mathrm{NBC}=$ & 2 & $\star$ & & & & & \\
\hline Branch & 1 & Node & 1 & $Q=$ & 270.00 & * & & & \\
\hline Branch & 2 & Node & 1 & $Q=$ & 270.00 & * & & & \\
\hline for Time & 10 & $\mathrm{NBC}=$ & 2 & * & & & & & \\
\hline Branch & 1 & Node & 1 & $Q=$ & 347.30 & * & & & \\
\hline Branch & 2 & Node & 1 & $\mathrm{Q}=$ & 347.30 & * & & & \\
\hline for Time & 11 & $\mathrm{NBC}=$ & 2 & * & & & & & \\
\hline Branch & 1 & Node & 1 & $Q=$ & 409.50 & * & & & \\
\hline Branch & 2 & Node & 1 & $\mathrm{Q}=$ & 409.50 & * & & & \\
\hline for Time & 12 & $\mathrm{NBC}=$ & 2 & * & & & & & \\
\hline Branch & 1 & Node & 1 & $Q=$ & 448.10 & * & & & \\
\hline Branch & 2 & Node & 1 & $\tilde{Q}=$ & 448.10 & * & & & \\
\hline for Time & 13 & $\mathrm{NBC}=$ & 2 & $\star$ & & & & & \\
\hline Branch & 1 & Node & 1 & $\mathrm{Q}=$ & 461.00 & * & & & \\
\hline Branch & 2 & Node & 1 & $\bar{Q}=$ & 461.00 & * & & & \\
\hline for Time & 14 & $\mathrm{NBC}=$ & 2 & * & & & & & \\
\hline Branch & 1 & Node & 1 & $Q=$ & 439.00 & * & & & \\
\hline Branch & 2 & Node & 1 & $Q=$ & 439.00 & * & & & \\
\hline for Time & 15 & $\mathrm{NBC}=$ & 2 & $\star$ & & & & & \\
\hline Branch & 1 & Node & 1 & $Q=$ & 394.10 & * & & & \\
\hline Branch & 2 & Node & 1 & $\mathrm{Q}=$ & 394.10 & * & & & \\
\hline for Time & 16 & $\mathrm{NBC}=$ & 2 & * & & & & . & \\
\hline Branch & 1 & Node & 1 & $Q=$ & 342.60 & * & & & \\
\hline Branch & 2 & Node & 1 & $\mathrm{Q}=$ & 342.60 & * & & & \\
\hline for Time & 17 & $\mathrm{NBC}=$ & 2 & * & & & & & \\
\hline Branch & 1 & Node & 1 & $Q=$ & 291.20 & * & & & \\
\hline Branch & 2 & Node & 1 & $Q=$ & 291.20 & * & & & \\
\hline for Time & 18 & $\mathrm{NBC}=$ & 2 & $\star$ & & & & & \\
\hline Branch & 1 & Node & 1 & $Q=$ & 243.00 & * & & & \\
\hline Branch & 2 & Node & 1 & $\mathrm{Q}=$ & 243.00 & * & & & \\
\hline
\end{tabular}

Figure 21 (continued). Input file, flow.in, for example 3. 


\begin{tabular}{|c|c|c|c|c|c|c|}
\hline for Time & 19 & $\mathrm{NBC}=$ & 2 & * & & \\
\hline Branch & 1 & Node & 1 & $Q=$ & 207.30 & * \\
\hline Branch & 2 & Node & 1 & $\bar{Q}=$ & 207.30 & * \\
\hline for Time & 20 & $\mathrm{NBC}=$ & 2 & * & & \\
\hline Branch & 1 & Node & 1 & $Q=$ & 174.90 & * \\
\hline Branch & 2 & Node & 1 & $\mathrm{Q}=$ & 174.90 & * \\
\hline for Time & 21 & $\mathrm{NBC}=$ & 2 & $\star$ & & \\
\hline Branch & 1 & Node & 1 & $Q=$ & 149.20 & * \\
\hline Branch & 2 & Node & 1 & $\mathrm{Q}=$ & 149.20 & * \\
\hline for Time & 22 & $\mathrm{NBC}=$ & 2 & $\star$ & & \\
\hline Branch & 1 & Node & 1 & $Q=$ & 128.60 & * \\
\hline Branch & 2 & Node & 1 & $Q=$ & 128.60 & * \\
\hline for Time & 23 & $\mathrm{NBC}=$ & 2 & $\star$ & & \\
\hline Branch & 1 & Node & 1 & $Q=$ & 111.40 & * \\
\hline Branch & 2 & Node & 1 & $Q=$ & 111.40 & * \\
\hline for Time & 24 & $\mathrm{NBC}=$ & 2 & $\star$ & & \\
\hline Branch & 1 & Node & 1 & $Q=$ & 94.320 & * \\
\hline Branch & 2 & Node & 1 & $\mathrm{Q}=$ & 94.320 & * \\
\hline for Time & 25 & $\mathrm{NBC}=$ & 2 & * & & \\
\hline Branch & 1 & Node & 1 & $Q=$ & 81.800 & * \\
\hline Branch & 2 & Node & 1 & $Q=$ & 81.800 & * \\
\hline for Time & 26 & $\mathrm{NBC}=$ & 2 & * & & \\
\hline Branch & 1 & Node & 1 & $Q=$ & 71.710 & * \\
\hline Branch & 2 & Node & 1 & $Q=$ & 71.710 & * \\
\hline for Time & 27 & $\mathrm{NBC}=$ & 2 & * & & \\
\hline Branch & 1 & Node & 1 & $Q=$ & 63.100 & * \\
\hline Branch & 2 & Node & 1 & $Q=$ & 63.100 & * \\
\hline for Time & 28 & $\mathrm{NBC}=$ & 2 & * & & \\
\hline Branch & 1 & Node & 1 & $Q=$ & 54.560 & $\star$ \\
\hline Branch & 2 & Node & 1 & $Q=$ & 54.560 & * \\
\hline for Time & 29 & $\mathrm{NBC}=$ & 2 & * & & \\
\hline Branch & 1 & Node & 1 & $Q=$ & 46.350 & $\star$ \\
\hline Branch & 2 & Node & 1 & $Q=$ & 46.350 & $\star$ \\
\hline for Time & 30 & $\mathrm{NBC}=$ & 2 & $\star$ & & \\
\hline Branch & 1 & Node & 1 & $Q=$ & 38.490 & $\star$ \\
\hline Branch & 2 & Node & 1 & $Q=$ & 38.490 & $\star$ \\
\hline for Time & 31 & $\mathrm{NBC}=$ & 2 & * & & \\
\hline Branch & 1 & Node & 1 & $Q=$ & 30.640 & $\star$ \\
\hline Branch & 2 & Node & 1 & $Q=$ & 30.640 & $\star$ \\
\hline for Time & 32 & $\mathrm{NBC}=$ & 2 & * & & \\
\hline Branch & 1 & Node & 1 & $Q=$ & 22.790 & $\star$ \\
\hline Branch & 2 & Node & 1 & $Q=$ & 22.790 & $\star$ \\
\hline for Time & 33 & $\mathrm{NBC}=$ & 2 & * & & \\
\hline Branch & 1 & Node & 1 & $Q=$ & 14.940 & * \\
\hline Branch & 2 & Node & 1 & $Q=$ & 14.940 & $\star$ \\
\hline for Time & 34 & $\mathrm{NBC}=$ & 2 & * & & \\
\hline Branch & 1 & Node & 1 & $Q=$ & 7.0870 & $\star$ \\
\hline Branch & 2 & Node & 1 & $Q=$ & 7.0870 & * \\
\hline for Time & 35 & $\mathrm{NBC}=$ & 2 & * & & \\
\hline Branch & 1 & Node & 1 & $Q=$ & 0.000 & * \\
\hline Branch & 2 & Node & 1 & $Q=$ & 0.000 & * \\
\hline for Time & 36 & $\mathrm{NBC}=$ & 0 & * & & \\
\hline 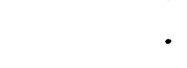 & & & & & & \\
\hline for Time & 64 & $\mathrm{NBC}=$ & 0 & 夫 & & \\
\hline
\end{tabular}

Figure 21 (continued). Input file, flow.in, for example 3. 
The other input file for DAFLOW, the DAFG file, used for example 3 is the shown in figure 22. As before, notice that there are three lines of text at the beginning and that the bed elevation, bed thickness and hydraulic conductivity are defined for each interior node ( 2 through 12, or 2 through 32). The bed elevation represents the elevation of the subreach, upstream of the ncde, at the midpoint of the ground-water cell. The ground-water cell that interacts with this subreach is identified in the last three columns. The format of the data is not important, but each column must be separated by at least 1 blank space. Following the bed interaction data is one line of text identifying the three flags input on the last line of the file. In this case, the print code for MODFLOW (IDAFCB) is 44, which means that the MODFLOW budget information is stored in file 44. The debug output option (IDBG) is set to zero, so the debugging information is not printed, and central differencing is used for ground-water head, (IDAFBK $=0$ ). 


\begin{tabular}{|c|c|c|c|c|c|c|c|}
\hline This i & s ins & ut for & DAFLOW/MODF & LOW & & & \\
\hline & & Bed & Bed & & GW node & of ex & xchange \\
\hline Brch & Node & Elev & Thickness & Conductivity & y Layer & Row & Column \\
\hline 1 & 2 & 25.300 & 1.00 & $1.00 \mathrm{E}-04$ & 1 & 1 & 1 \\
\hline 1 & 3 & 24.700 & 1.0 & $1.00 \mathrm{E}-04$ & 1 & 2 & 2 \\
\hline 1 & 4 & 24.100 & 1.0 & $1.00 \mathrm{E}-04$ & 1 & 3 & 3 \\
\hline 1 & 5 & 23.500 & 1.0 & $1.00 \mathrm{E}-04$ & 1 & 4 & 4 \\
\hline 1 & 6 & 22.900 & 1.0 & 1. $00 \mathrm{E}-04$ & 1 & 5 & 5 \\
\hline 1 & 7 & 22.300 & 1.0 & $1.00 \mathrm{E}-04$ & 1 & 6 & 6 \\
\hline 1 & 8 & 21.700 & 1.0 & $1.00 \mathrm{E}-04$ & 1 & 7 & 7 \\
\hline 1 & 9 & 21.100 & 1.0 & $1.00 \mathrm{E}-04$ & 1 & 8 & 8 \\
\hline 1 & 10 & 20.500 & 1.0 & $1.00 \mathrm{E}-04$ & 1 & 9 & 9 \\
\hline 1 & 11 & 19.900 & 1.0 & $1.00 \mathrm{E}-04$ & 1 & 10 & 10 \\
\hline 1 & 12 & 19.300 & 1.0 & $1.00 \mathrm{E}-04$ & 1 & 11 & 11 \\
\hline 2 & 2 & 25.300 & 1.00 & $1.00 \mathrm{E}-04$ & 1 & 1 & 21 \\
\hline 2 & 3 & 24.700 & 1.0 & $1.00 \mathrm{E}-04$ & 1 & 2 & 20 \\
\hline 2 & 4 & 24.100 & 1.0 & $1.00 \mathrm{E}-04$ & 1 & 3 & 19 \\
\hline 2 & 5 & 23.500 & 1.0 & $1.00 \mathrm{E}-04$ & 1 & 4 & 18 \\
\hline 2 & 6 & 22.900 & 1.0 & $1.00 \mathrm{E}-04$ & 1 & 5 & 17 \\
\hline 2 & 7 & 22.300 & 1.0 & $1.00 \mathrm{E}-04$ & 1 & 6 & 16 \\
\hline 2 & 8 & 21.700 & 1.0 & $1.00 \mathrm{E}-04$ & 1 & 7 & 15 \\
\hline 2 & 9 & 21.100 & 1.0 & $1.00 E-04$ & 1 & 8 & 14 \\
\hline 2 & 10 & 20.500 & 1.0 & $1.00 \mathrm{E}-04$ & 1 & 9 & 13 \\
\hline 2 & 11 & 19.900 & 1.0 & $1.00 \mathrm{E}-04$ & 1 & 10 & 12 \\
\hline 2 & 12 & 19.300 & 1.0 & $1.00 \mathrm{E}-04$ & 1 & 11 & 11 \\
\hline 3 & 2 & 19.300 & 1.00 & $1.00 \mathrm{E}-04$ & 1 & 11 & 11 \\
\hline 3 & 3 & 18.700 & 1.0 & 1. $.00 \mathrm{E}-04$ & 1 & 12 & 11 \\
\hline 3 & 4 & 18.100 & 1.0 & $1.00 \mathrm{E}-04$ & 1 & 13 & 11 \\
\hline 3 & 5 & 17.500 & 1.0 & $1.00 \mathrm{E}-04$ & 1 & 14 & 11 \\
\hline 3 & 6 & 1.6 .900 & 1.0 & $1.00 \mathrm{E}-04$ & 1 & 15 & 11 \\
\hline 3 & 7 & 16.300 & 1.0 & $1.00 \mathrm{E}-04$ & 1 & 16 & 11 \\
\hline 3 & 8 & 15.700 & 1.0 & $1.00 \mathrm{E}-04$ & 1 & 17 & 11 \\
\hline 3 & 9 & 15.100 & 1.0 & $1.00 \mathrm{E}-04$ & 1 & 18 & 11 \\
\hline 3 & 10 & 14.500 & 1.0 & $1.00 \mathrm{E}-04$ & 1 & 19 & 11 \\
\hline 3 & 11 & 13.900 & 1.0 & $1.00 \mathrm{E}-04$ & 1 & 20 & 11 \\
\hline 3 & 12 & 13.300 & 1.0 & $1.00 \mathrm{E}-04$ & 1 & 21 & 11 \\
\hline 3 & 13 & 12.700 & 1.0 & $1.00 \mathrm{E}-04$ & 1 & 22 & 11 \\
\hline 3 & 14 & 12.100 & 1.0 & $1.00 \mathrm{E}-04$ & 1 & 23 & 11 \\
\hline 3 & 15 & 11.500 & 1.0 & $1.00 \mathrm{E}-04$ & 1 & 24 & 11 \\
\hline 3 & 16 & 10.900 & 1.0 & $1.00 \mathrm{E}-04$ & 1 & 25 & 11 \\
\hline 3 & 17 & 10.300 & 1.0 & $1.00 \mathrm{E}-04$ & 1 & 26 & 11 \\
\hline 3 & 18 & 9.700 & 1.0 & $1.00 \mathrm{E}-04$ & 1 & 27 & 11 \\
\hline 3 & 19 & 9.100 & 1.0 & $1.00 E-04$ & 1 & 28 & 11 \\
\hline 3 & 20 & 8.500 & 1.0 & $1.00 \mathrm{E}-04$ & 1 & 29 & 11 \\
\hline 3 & 21 & 7.900 & 1.0 & $1.00 \mathrm{E}-04$ & 1 & 30 & 11 \\
\hline 3 & 22 & 7.300 & 1.0 & $1.00 \mathrm{E}-04$ & 1 & 31 & 11 \\
\hline 3 & 23 & 6.700 & 1.0 & $1.00 E-04$ & 1 & 32 & 11 \\
\hline 3 & 24 & 6.100 & 1.0 & $1.00 \mathrm{E}-04$ & 1 & 33 & 11 \\
\hline 3 & 25 & 5.500 & 1.0 & $1.00 \mathrm{E}-04$ & 1 & 34 & 11 \\
\hline 3 & 26 & 4.900 & 1.0 & $1.00 \mathrm{E}-04$ & 1 & 35 & 11 \\
\hline 3 & 27 & 4.300 & 1.0 & $1.00 \mathrm{E}-04$ & 1 & 36 & 11 \\
\hline 3 & 28 & 3.700 & 1.0 & $1.00 \mathrm{E}-04$ & 1 & 37 & 11 \\
\hline 3 & 29 & 3.100 & 1.0 & $1.00 \mathrm{E}-04$ & 1 & 38 & 11 \\
\hline 3 & 30 & 2.500 & 1.0 & $1.00 \mathrm{E}-04$ & 1 & 39 & 11 \\
\hline 3 & 31 & 1.900 & 1.0 & $1.00 \mathrm{E}-04$ & 1 & 40 & 11 \\
\hline 3 & 32 & 1.300 & 1.0 & $1.00 \mathrm{E}-08$ & 1 & 41 & 11 \\
\hline IDAFCF & $\mathrm{B}$ IDBG & IDAFBK & & & & & \\
\hline 44 & 0 & 0 & & & & & \\
\hline
\end{tabular}

Figure 22. Input file, DAFG, for example 3. 
All additional input files for MODFLOW are shown in Appendix D for example 3.

Selected output of MODFLOW/DAFLOW is shown in figure 23 for the MODFLOW time steps 6 and 11. At time step 6 (hour 2.5-3.0), the inflow at the upstream boundary is near the peak (figure 24), and there is no flow in the lower part of the downstream branch. Nine iterations are required (figure 23 ) for convergence during this time of rapidly changing conditions. The leading edge of the hydrograph is near node 4 in branch 3 for the first half of the MODFLCW time step. It is normal for very small negative streamflow to be computed as the hydrograph advances over a dry bed. The negative values are caused by truncation errors in the approximate solution. The warning messages may occur for each iteration, but only the values for one iteration are shown in figure 23 . The negative values should remain less than the flow tolerance selected for DAFLOW, which in this case $0.01 \mathrm{ft}^{3} / \mathrm{s}$. The step number shown in the negative flow warning represents the DAFLOW time step within the MODFLOW time step. The output indicates that the streamflow at branch 1 , node 12 is only $27.5 \mathrm{ft}^{3} / \mathrm{s}$ during the first half of the MODFLO'V time step, but increases to $153.9 \mathrm{ft}^{3} / \mathrm{s}$ during the second half of the time step. The streamflc $\mathrm{v}$ is zero at the downstream end of branch 3 for the entire time step. As can be seen from the volumetric budget, between hours 2.5 and 3.0 , the average seepage from the stream to the aquifer is $16,130,487 \mathrm{ft}^{3} /$ day, or $187 \mathrm{ft}^{3} / \mathrm{s}$. The seepage from the aquifer to the stream is virtually zero $\left(0.0049338 \mathrm{ft}^{3} /\right.$ day).

During time-step 11 (hours 5.0-5.5), most of the flow has entered the system, and the leading edge of the hydrograph has passed the downstream boundary. The entire channel has some flow, and there are no negative flow warnings. Conditions are still changing rapidly, so 7 iterations are required for convergence. Seepage from the stream to the aquifer $\left(15,748,558 \mathrm{ft}^{3} / \mathrm{day}=182 \mathrm{ft}^{3} / \mathrm{s}\right)$ is less than the maximum value of $278 \mathrm{ft}^{3} / \mathrm{s}$ which occurred between hours 3.5 and 4.0 . This is the first time step for which significant return flow $\left(1.26 \mathrm{ft}^{3} / \mathrm{s}\right)$ occurs from the aquifer to the stream. 
MODFLOW

U.S. GEOLOGICAL SURVEY MODULAR FINITE-DIFFERENCE GROUND-WATER FLOW MODEL

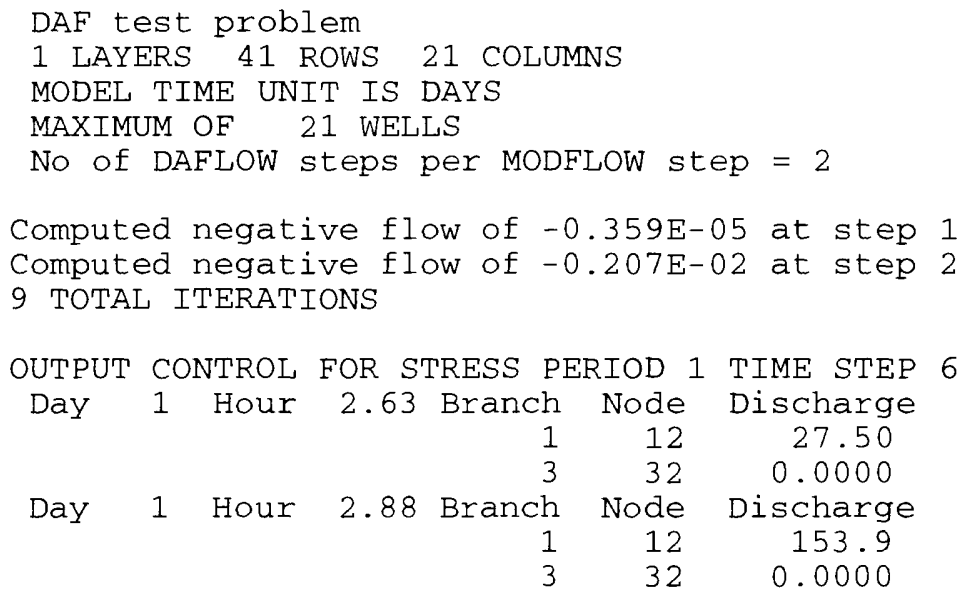

VOLUMETRIC BUDGET OF ENTIRE MODEL, END OF TIME STEP 6, STRESS PERIOD 1

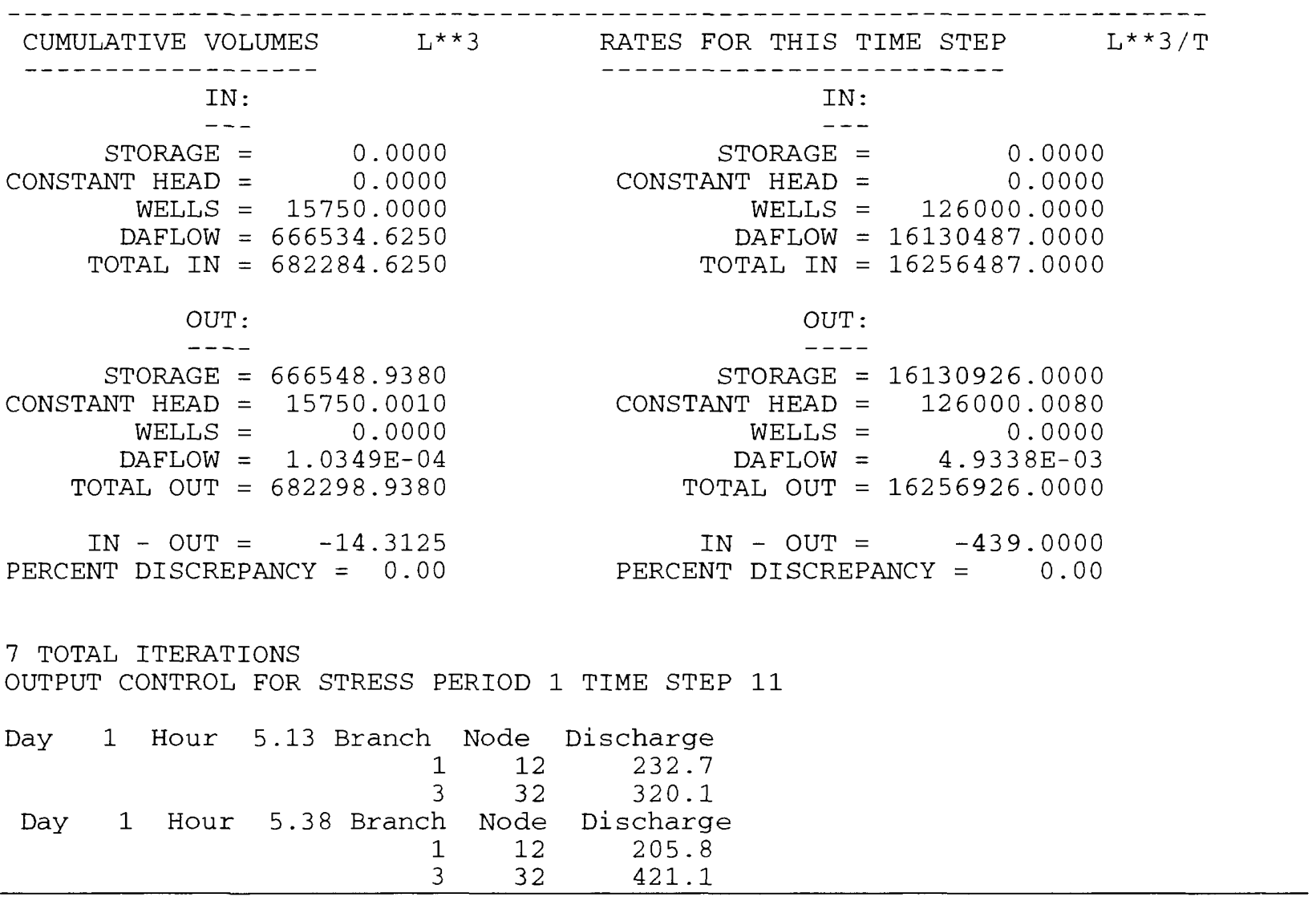

Figure 23. Selected output of the Modular Finite-Difference Ground-Water Flow model at end of time steps 6 and 11, for example 3. 


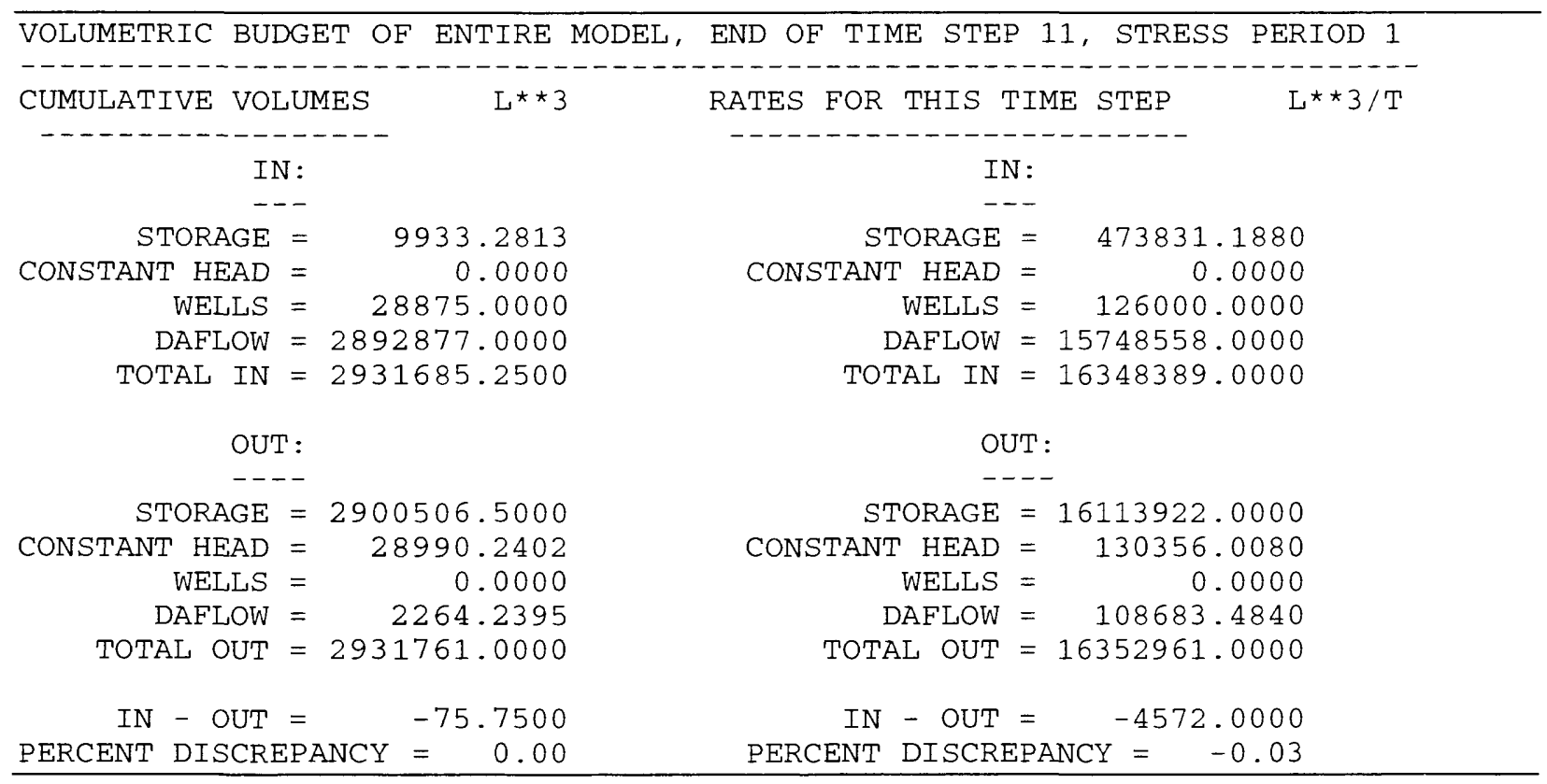

Figure 23 (continued). Selected output of the Modular Finite-Difference Ground-Water Flow model at end of time steps 6 and 11, for example 3.

The channel flow at the upstream and downstream boundaries of the system as well as at the upstream end of Branch 3 are shown in figure 24. The flow distribution that would have occurred if the stream/aquifer interaction had not occurred is also shown as dashed lines to illustrate the effect of bank storage on the flow hydrograph. 


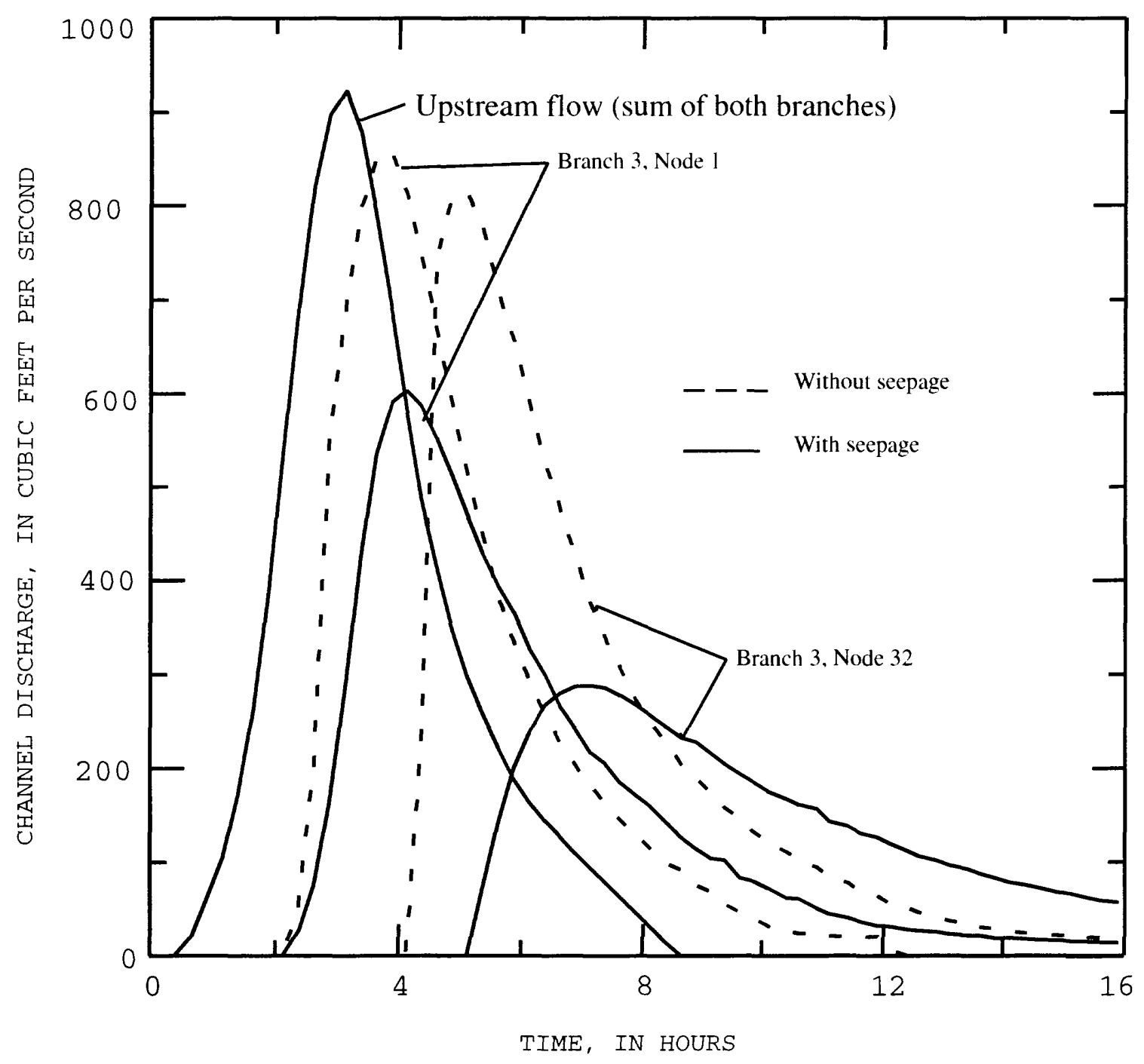

Figure 24. Flow distribution at selected points of the channel in example 3, illustratina the bank-storage effect on the flow hydrograph. 
The effective flow into and out of the aquifer as a function of time is shown in figure 25 . These values were obtained from the volumetric budget of the entire model shown in the MODFLOW output (figure 23). The peak flow into the aquifer of nearly $300 \mathrm{ft}^{3} / \mathrm{s}$ occurs at about hour 4, which corresponds to the time that the peak channel flow is near the junction. The flow into the aquifer accounts for most of the attenuation in peak channel flow between the upstream boundary and the junction. Return flow from the aquifer begins in the upstream reaches a little after hour 4, after the flow at the upstream boundary has been reduced to about half of its peak value. The flow out of the aquifer peaks between hour 9 and 10 after the channel flow at tho downstream boundary is well past its peak.

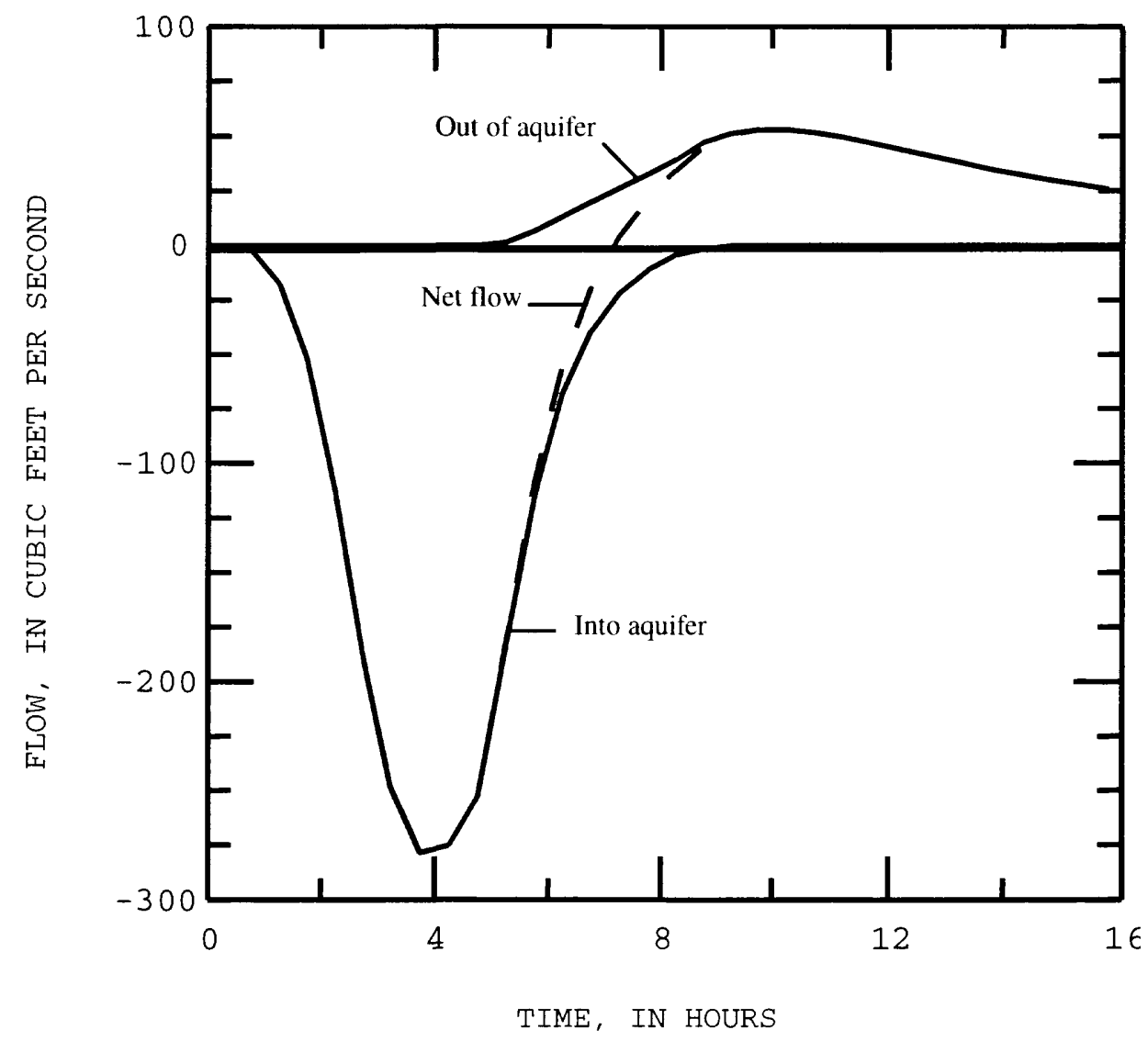

Figure 25. Flow into and out of the aquifer of example 3 as a function of time. 


\section{SUMMARY}

Computer models are widely used to simulate ground-water flow, as well as flow in rivers and streams, for evaluating and managing water resources. To facilitate the simulation of the interaction of surface water and ground water, the surface-water flow model (DAFLOW) was linked to the modular, finite-difference, ground-water flow model (MODFLOW). The linkage was accomplished by separating the code of the DAFLOW model into a group of subroutines that can be called by MODFLOW. The subroutines were structured such that multiple DAFLCW time steps can be run iteratively for a single MODFLOW time step, and the leakage to each ground-water cell is averaged over the MODFLOW time step.

The DAFLOW model, which solves the diffusive-wave form of the surface-water flow equations, is designed to simulate flow in upland stream systems where flow reversals do not occur, and backwater conditions are not severe. If these two conditions are satisfied, the DAFLOW model can be applied with good accuracy using minimal field data.

This report documents the modifications to the DAFLOW model needed for it to be linked to the MODFLOW package, describes the calls necessary to implement DAFLOW with MODFLOW, and describes the input files necessary to run DAFLOW with MODFLOW. Three example applications illustrate the information contained in the output files and allow the user to assess the accuracy of the solutions of the combined models.

\section{REFERENCES CITED}

Beven, Keith, and Michael J. Kirkby, 1993, Channel Network Hydrology: John Wiley \& Sons. New York, 319 p.

Boning, C.W., 1974, Generalization of stream travel rates and dispersion characteristics from time-of-travel measurements: Journal of Research of the U.S. Geological Survey, v. 2, no. 4, July-August, p. 495-499.

Boyłe, J.M., and Spahr, N.E., 1985, Traveltime, longitudinal-dispersion, reaeration, and basin characteristics of the White River, Colorado and Utah: U.S. Geological Survey WaterResources Investigations Report 85-4050, $53 \mathrm{p}$.

Carslaw, H.S., and Jaeger, J.C., 1959, Conduction of heat in solids (2d ed.): New York, Oxford University Press, $510 \mathrm{p}$.

Chow, Ven Te, 1959, Open-Channel Hydraulics: McGraw-Hill Civil Engineering Series, McGraw-Hill Book Company, Inc., New Yorke. 680 p.

Cooper, H.H., and M.I. Rorabaugh, 1963, Ground-water movements and bank storage due to flood stages in surface streams: U.S. Geological Survey Water-Supply Paper 1536-J, p. 343-366. 
Harbaugh, A.W., and McDonald, M.G., 1996, User's documentation for MODFLOW-96, an update to the U.S. Geological Survey modular finite-difference ground-water flow model: U.S. Geological Survey Open-File Report 96-485, 56 p.

Inman, Ernest J., 1987, Simulation of flood hydrographs for Georgia streams: U.S. Geological Survey Water-Supply Paper 2317, 26 p.

Jennings, M.E., W.O. Thomas, Jr., and H.C. Riggs, 1994, Nationwide summary of U.S. Geological Survey regional regression equations for estimating magnitude and frequency of floods for ungaged sites, 1993: U.S. Geological Survey Water-Resources Investigations 944002, $196 \mathrm{p}$.

Jobson, H.E., 1989, Users manual for an open-channel streamflow model based on the diffusion analogy: U.S. Geological Survey Water-Resources Investigations 89-4133, 73 p.

Jobson, H.E., and Schoellhamer, D.H., 1987, Users manual for a branched Lagrangian transport model: U.S. Geological Survey Water-Resources Investigations 87-4163, 80 p.

Kilpatrick, F.A., and H.H. Barnes, Jr., 1964, Channel geometry of Piedmont streams as related to frequency of floods: U.S. Geological Survey Professional Paper 422-E, 10 p.

Kleitz, M., 1877, Note sur la theorie du mouvement non permanent des liquides et sur application a la propagation des crues des rivieres (Note on the theory of unsteady flow of liquids and on application to flood propagation in rivers): Annales des ponts et chaussees, ser. 5, vol. 16, 2e semestre, p. 133-196.

Leopold, L.B., and Maddock, Thomas, 1953, The hydraulic geometry of stream channels and some physiographic implications: U.S. Geological Survey Professional Paper 252, 57 p.

Leopold, L.B., and Miller, J.P., 1956, Ephemeral streams--hydraulic factors and their relation to drainage net: U.S. Geological Survey Professional Paper 282-A, 36 p.

McDonald, M.G., and Harbaugh, A.W., 1988, A modular three-dimensional finite differerse ground-water flow model: U.S. Geological Survey Techniques of Water-Resources Investigations Book 6, Chapter A1, $586 \mathrm{p}$.

Oakes, D. B., and Wilkinson, W.B., 1972, Modeling of ground water and surface water systems: I-Theoretical relationships between ground water abstraction and base flow: Reading, Great Britain, Reading Bridge House, Water Resources Board, no. 16, 37 p.

Osterkamp, Waite R., 1980, Sediment-morphology relations of alluvial channels: Americ $n$ Society of Civil Engineers, Proceedings of the Symposium on Watershed Management '80: ASCE, Boise, ID, July 21-23, 1980. 
Prudic, David E., 1989, Documentation of a computer program to simulate stream-aquifer relations using a modular, finite-difference, ground-water flow model: U.S. Geological Survey Open-File Report no. 88-729, Carson City, Nevada, 113 pages.

Saint-Venant, A. J. C. Barre, 1871, Theorie du mouvement non permanent des eaux, avec application aux crues des rivieres et a l'introduction des marees dans leur lits (Theory of the non-permanent movement of waters with application to the floods of rivers and to the introduction of the tides within their beds), Comptes rendus des seances de l'Academie des Sciences, vol. 73, p. 147-154 and 237-240.

Seddon, James A., 1900, River hydraulics: Transactions, American Society of Civil Engineers, vol. 43 , p. $179-229$.

Stall, J.B., and Yang, Chih Ted, 1970, Hydraulic geometry of 12 selected stream systems of the United States: Illinois State Water Survey Research Report No. 32, July, 73 p.

Swain, Eric D. and Eliezer J. Wexler, 1993: A coupled surface-water and ground-water flow model for simulation of stream-aquifer interaction: : U.S. Geological Survey Open-File Report no. 92-138, Tallahassee, Florida, 162 pages.

Wilkinson, James A., 1945, Translatory waves in natural channels: Transactions, American Society of Civil Engineers, vol. 110, p. 1203-1225.

Wolman, M. Gordon, and Luna B. Leopold, 1957, River flood plains: Some observations on their formation: U.S. Geological Survey Professional Paper 282-C, p. 87-107. 
APPENDIXES

Modifications to the DAFLOW for Coupling to the MODFLOW

61 


\section{APPENDIX A. SOURCE CODE FOR DAFLOW SUBROUTINES}

The stand-alone version of DAFLOW consists of a main program and a series of subroutines. This code is normally stored in three primary files, called daflow.for, gutsdaf.for, and rtedaf.for. Two additional files, which are included in the code by use of INCLUDE statements, must also be available. These files are params.inc and startdaf.com. When used with MODFLOW, the main program is replaced by additional subroutines that perform the ground-water specific functions. This file is called dafl.for. An additional include file called ground.com is also needed.

All USGS hydrologic analysis software is available for electronic retrieval by means of either the World-Wide Web (WWW) at http://water.usgs.gov/software or by anonymous File Transfer Protocol (FTP) from water.usgs.gov in the /pub/software/surface_water directory.

In addition to the electronically available information, all code is listed below, in the following order: daflow.for, gutsdaf.for, rtedaf.for, dafl.for, params.inc, startdaf.com, and ground.com. 


\section{Code in the file daflow.for}

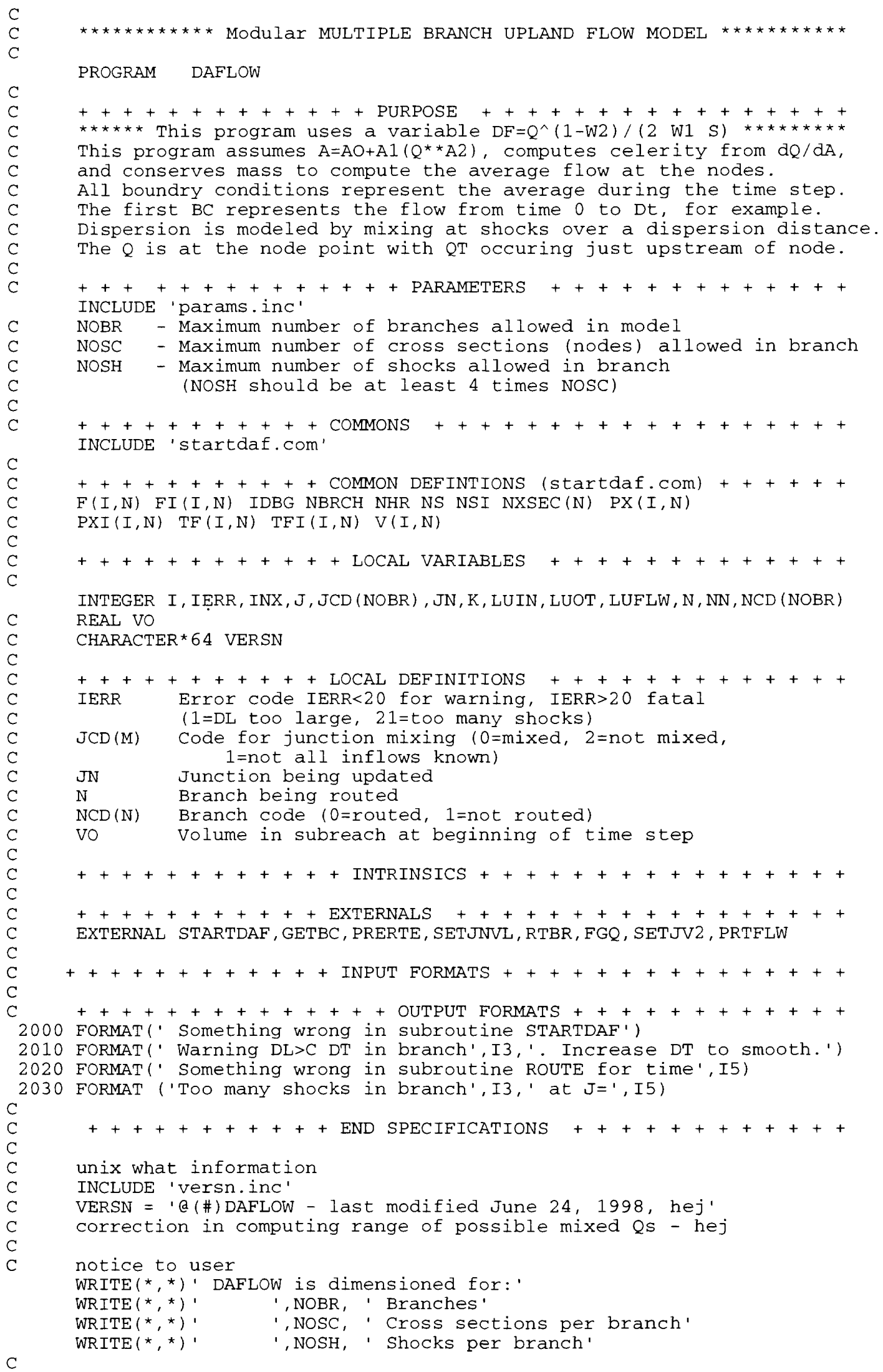




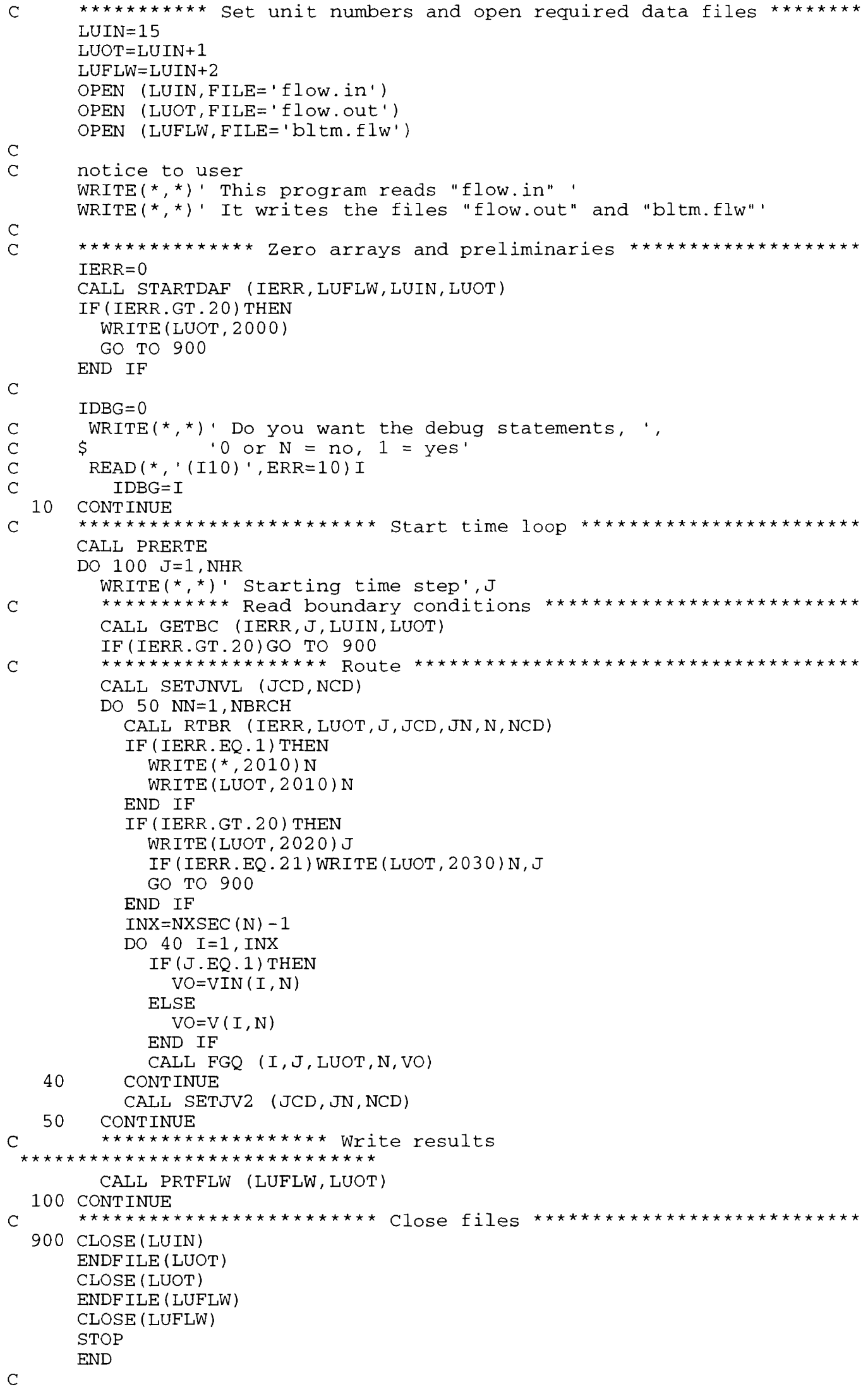




\section{Code in the file gutsdaf.for}

$+++++++++++++\operatorname{PURPOSE}+++++++++++++++t$

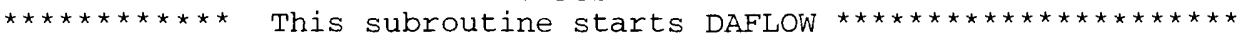
DAFLOW uses a variable $D F=Q^{\wedge}(1-\mathrm{W} 2) /(2 \mathrm{~W} 1 \mathrm{~S})$ and assumes

$\mathrm{A}=\mathrm{AO}+\mathrm{A} 1\left(\mathrm{Q}^{*}{ }^{\star} \mathrm{A} 2\right)$, computes celerity from $\mathrm{dQ} / \mathrm{dA}$, conserves mass to compute the average flow at the nodes. All boundry conditions represent the average during the time step. The first BC represents the flow from time 0 to $D t$, for example. Dispersion is modeled by mixing at shocks over a dispersion distance.

The $Q$ is at the node point with QT occuring just upstream of node.

++++++++++++++ PARAMERERS +++++++++++++ INCLUDE 'params.inc'

NOBR - Maximum number of branches allowed in model

NOSC - Maximum number of cross sections (nodes) allowed in branch

NOSH - Maximum number of shocks allowed in branch (NOSH should be at least 4 times NOSC)

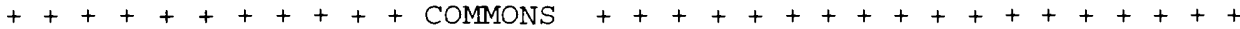
INCLUDE 'startdaf.com'

++++++++++ COMMON VARIBLES (startdaf.com) +++++++ $A O(I, N) \quad A 1(I, N) \quad A 2(I, N) \quad F(K, N) \quad F I(K, N)$ DT IENG IOUT $(I, N)$

JNCD(N) JNCU(N) JGO JTS NBRCH NHR NHRR NJNCT NS(N) NSI(N) NXSEC(N) $\operatorname{PF}(N) \quad \operatorname{PX}(\mathrm{K}, N) \quad \operatorname{PXI}(\mathrm{K}, \mathrm{N}) \quad \mathrm{QI} \quad \mathrm{SL}(I, N) \quad \mathrm{TF}(I, N) \quad \operatorname{TFI}(I, N) \quad \operatorname{TIME} V I N(I, N)$ VI $W 1(I, N)$ W2 $(I, N) \quad X(I, N) \quad X F A C T$

++++++++++++ LOCAL VARIABLES +++++++++++++ INTEGER I, IERR, J , K, LUFLW, LUIN, LUOT , N

REAL A, AA

C CHARACTER * 64 VERSN CHARACTER $* 80$ TITLE

$\mathrm{C}$
$\mathrm{C}$
$\mathrm{C}$
$\mathrm{C}$
$\mathrm{C}$
$\mathrm{C}$
$\mathrm{C}$ +++++++++++ LOCAL DEFINITIONS +++++++++++++ IERR Error code ( $0=0 k, 20<s t o p$ as gracefully as you can)

TITLE Title of program ( 80 characters max)

$++++++++++++\operatorname{INTRINSICS}+++++++++++++++$ INTRINSIC FLOAT

C +++++++++++ EXTERNALS ++++++++++++++++ 1000 FORMAT (A)

1010 FORMAT (20X, I 10$)$

1020 FORMAT (20X, F10.3)

1030 FORMAT $(13 \mathrm{X}, \mathrm{I} 3,16 \mathrm{X}, \mathrm{F} 5.2,16 \mathrm{X}, \mathrm{I} 3,8 \mathrm{X}, \mathrm{I} 3)$

C

C $+++++++++++++++++\operatorname{OUTPUT}$ FORMATS +++++++++++++ 2000 FORMAT $(1 \mathrm{X}, \mathrm{A}, /)$

2010 FORMAT ('The', I3,' Branch Model with', I3,' Internal Junctions',

\# ' is run', I5,' Time Steps each',F5.2,' hours long.')

2020 FORMAT ('The Model starts at',F6.2,' hours past midnight.')

2030 FORMAT ("The node output is given in "bltm.out" every', I4,

\# ' time steps.')

2040 FORMAT ('Input units are Metric (Meters \& river kilometers')

2050 FORMAT ('Input units are English (feet and river miles)')

2060 FORMAT (" Width=W1 (Q)**W2')

2070 FORMAT ('Cross sectional area $=A O+A 1\left(Q^{*}{ }^{*} \mathrm{~A} 2\right)$ ')

2080 FORMAT (" $A O=$ Cross sectional area at zero flow. ')

2090 FORMAT ( /,28X, ** * INITIAL CONDITIONS * * * ')

2100 FORMAT (/,' node Mi/km Disch A $\$$ 'W2 AO') A2 A2 W1

2110 FORMAT ( /, 'Branch', I 4,' Extends from JNCT', I3,' to JNCT', I3,

$\$$ ' and receives',F5.2,' of flow at JNCT', I3,1)

2120 FORMAT (I5, F8.2,9G11.4)

2130 FORMAT $(/, 25 \mathrm{x}, 1 * \star \star \star$ OUTPUT $*$ * $*,, /)$ 


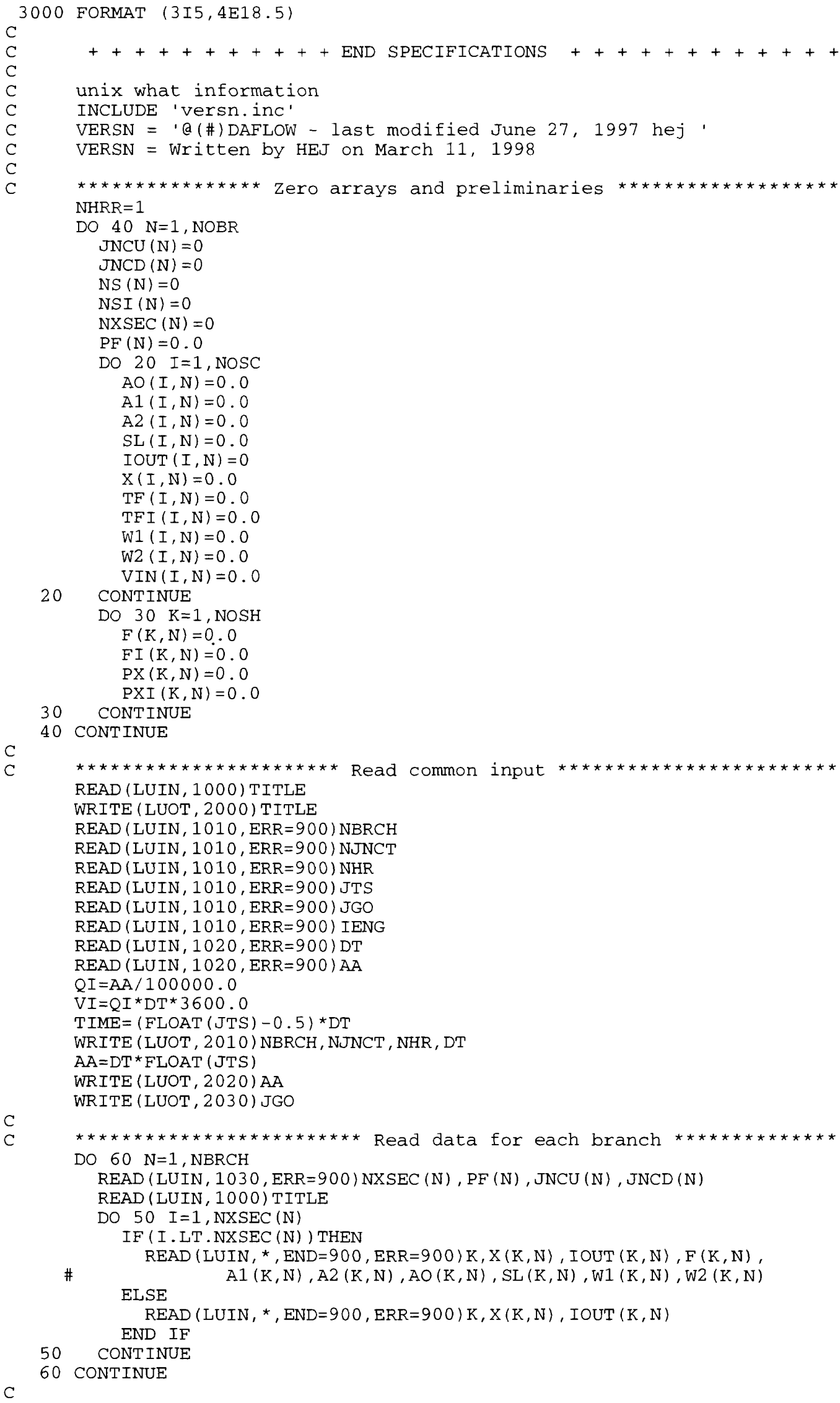


C $\star \star \star \star \star$ Make preliminary computation and write initial conditions $\star \star$ IF ( IENG. EQ. O) THEN

Metric units

C Metric units

C XFACT $=1609.34$

$\mathrm{XFACT}=1000.0$

ELSE

C

English units

WRITE (LUOT, 2050)

$\mathrm{XFACT}=5280.00$

END IF

WRITE (LUOT, 2070)

WRITE (LUOT, 2080)

C

WRITE (LUOT, 2060)

WRITE (LUOT, 2090)

WRITE (LUOT, 2100)

$\mathrm{J}=0$

DO $80 \mathrm{~N}=1, \mathrm{NBRCH}$

$\operatorname{NS}(N)=\operatorname{NXSEC}(N)-1$

$\operatorname{NSI}(\mathrm{N})=\mathrm{NS}(\mathrm{N})$

WRITE (LUOT, 2110) N, JNCU (N), JNCD (N), PF (N), JNCU (N)

DO $70 \quad I=1, \operatorname{NXSEC}(\mathrm{N})$

IF (I.LT.NXSEC (N) ) THEN

$\operatorname{PX}(I, N)=\mathrm{X}(I, N) \star X F A C T$

$\operatorname{PXI}(I, N)=\operatorname{PX}(I, N)$

$F I(I, N)=F(I, N)$

IF (F (I,N).GT .0.0) THEN

$A=A O(I, N)+A 1(I, N) \star(F(I, N) \star \star A 2(I, N))$

$A A=W 1(I, N) *(F(I, N) * * W 2(I, N))$

ELSE

$A=A O(I, N)$

$A A=0.0$

END IF

$\operatorname{VIN}(I, N)=A^{*} X F A C T *(X(I+1, N)-X(I, N))$

IF (I.GT. 1) THEN

$\mathrm{TF}(I, N)=\mathrm{F}(I, N)-\mathrm{F}(I-1, N)$

$\operatorname{TFI}(I, N)=\mathrm{TF}(I, N)$

END IF

WRITE (LUOT , 2120) I, X (I,N), F(I,N), A, AA, SL (I,N), ELSE WRITE (LUFLW, 3000) J,N, I, F (I,N), A, AA, TF (I,N)

WRITE (LUOT , 2120) I, X (I,N), F (I-1,N)

WRITE (LUFLW, 3000$) \mathrm{J}, N, \operatorname{NXSEC}(N), F(I-1, N)$

END IF

$X(I, N)=X(I, N) * X F A C T$

70

CONTINUE

C

80 CONTINUE

WRITE ( LUOT , 2130)

GO TO 999

900 IERR $=22$

999 RETURN

END

C

SUBROUTINE GETBC (IERR, J,LUIN, LUOT)

C

$++++++++++++++\operatorname{PURPOSE}+++++++++++++++++$ $\star \star \star \star \star \star$ This subroutine reads the boundary conditions for DAFLOW $* \star \star$

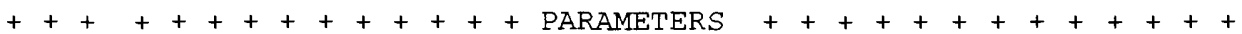
INCLUDE 'params.inc'

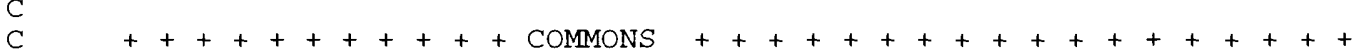
INCLUDE 'startdaf.com'

+++++++++++ COMMON VARIABLES (startdaf.com) ++++++ DT IDBG JTS TIME TRB $(I, N)$

++++++++++ LOCAL VARIABLES +++++++++++ INTEGER I, IERR, J, JJ , K, LUIN, LUOT, N, NBC 


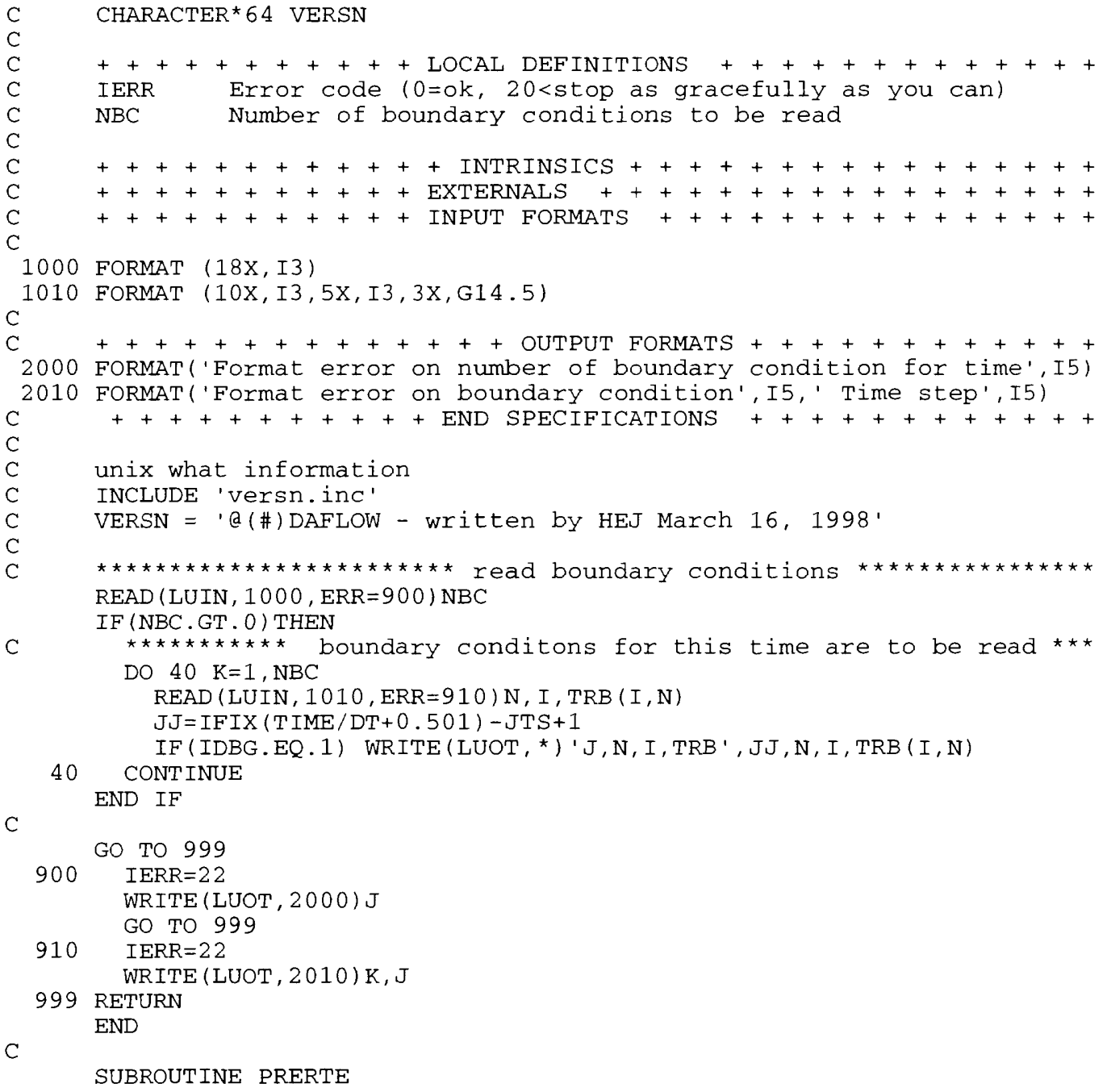




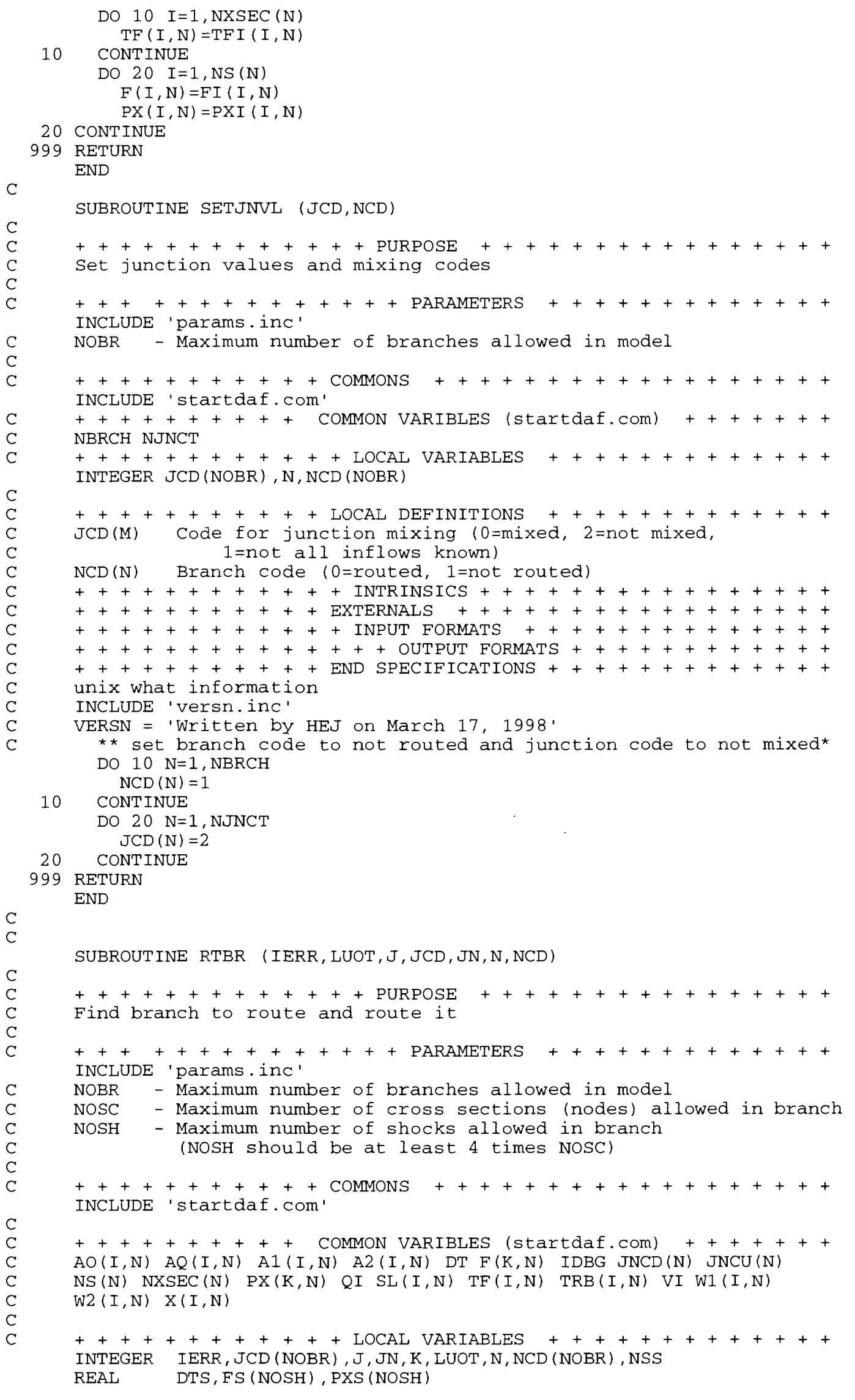




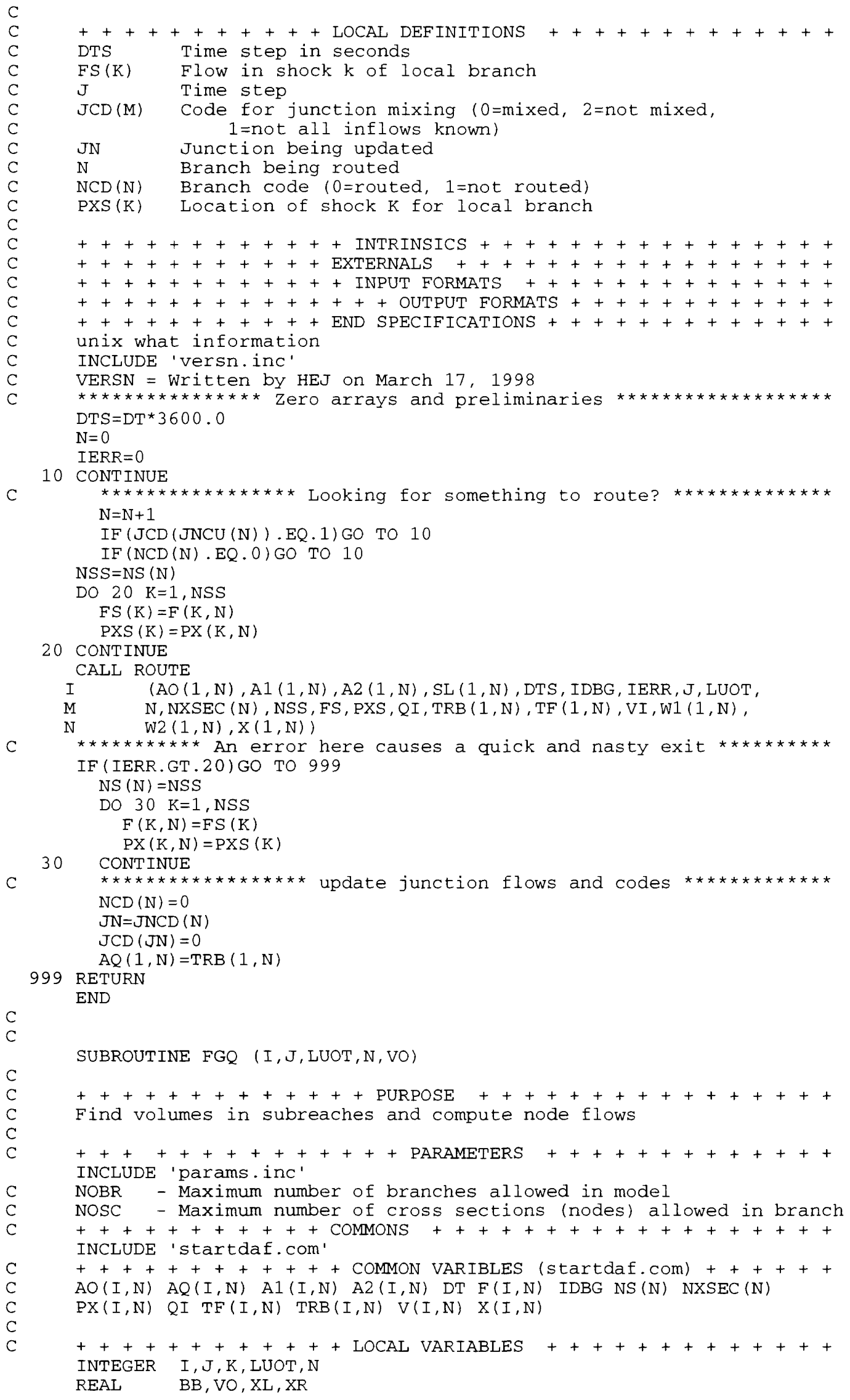




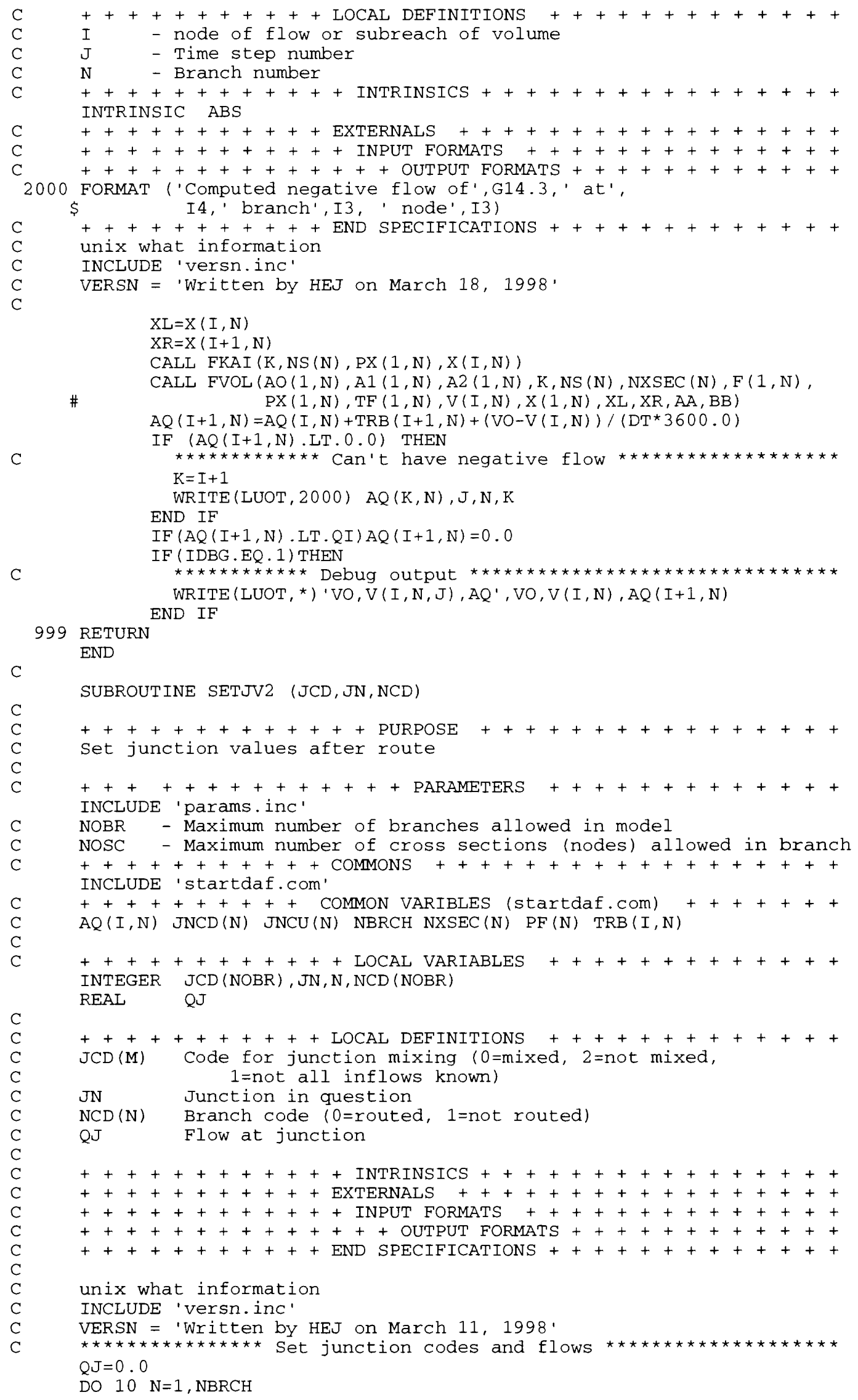




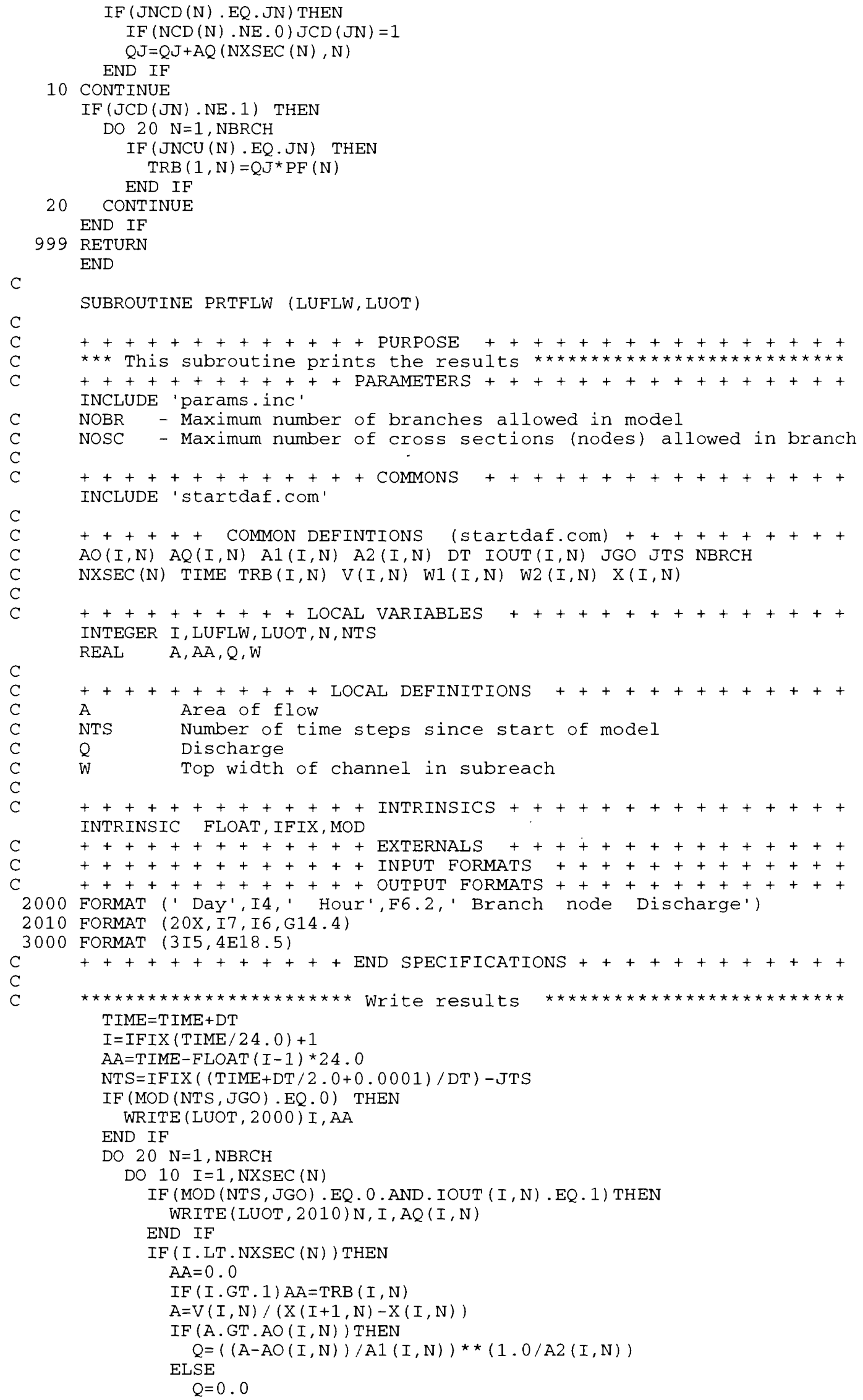




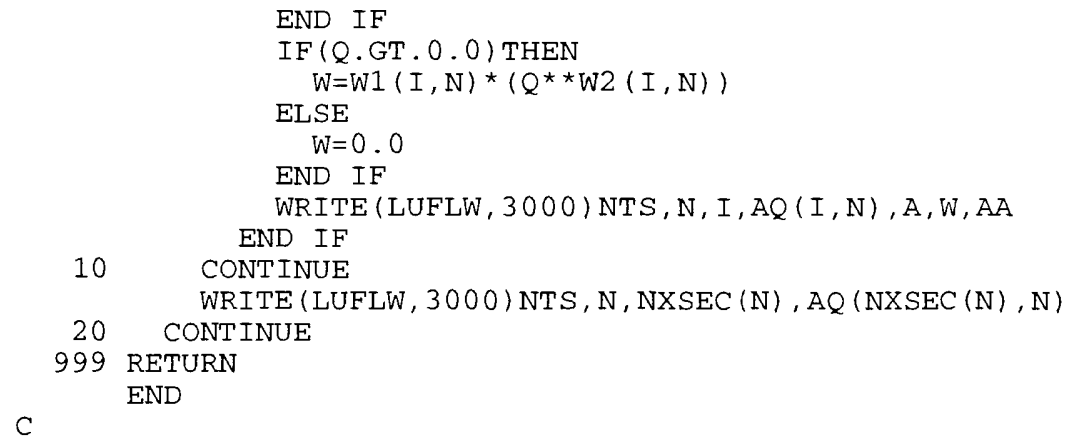

C 


\section{Code in the file rtedaf.for}

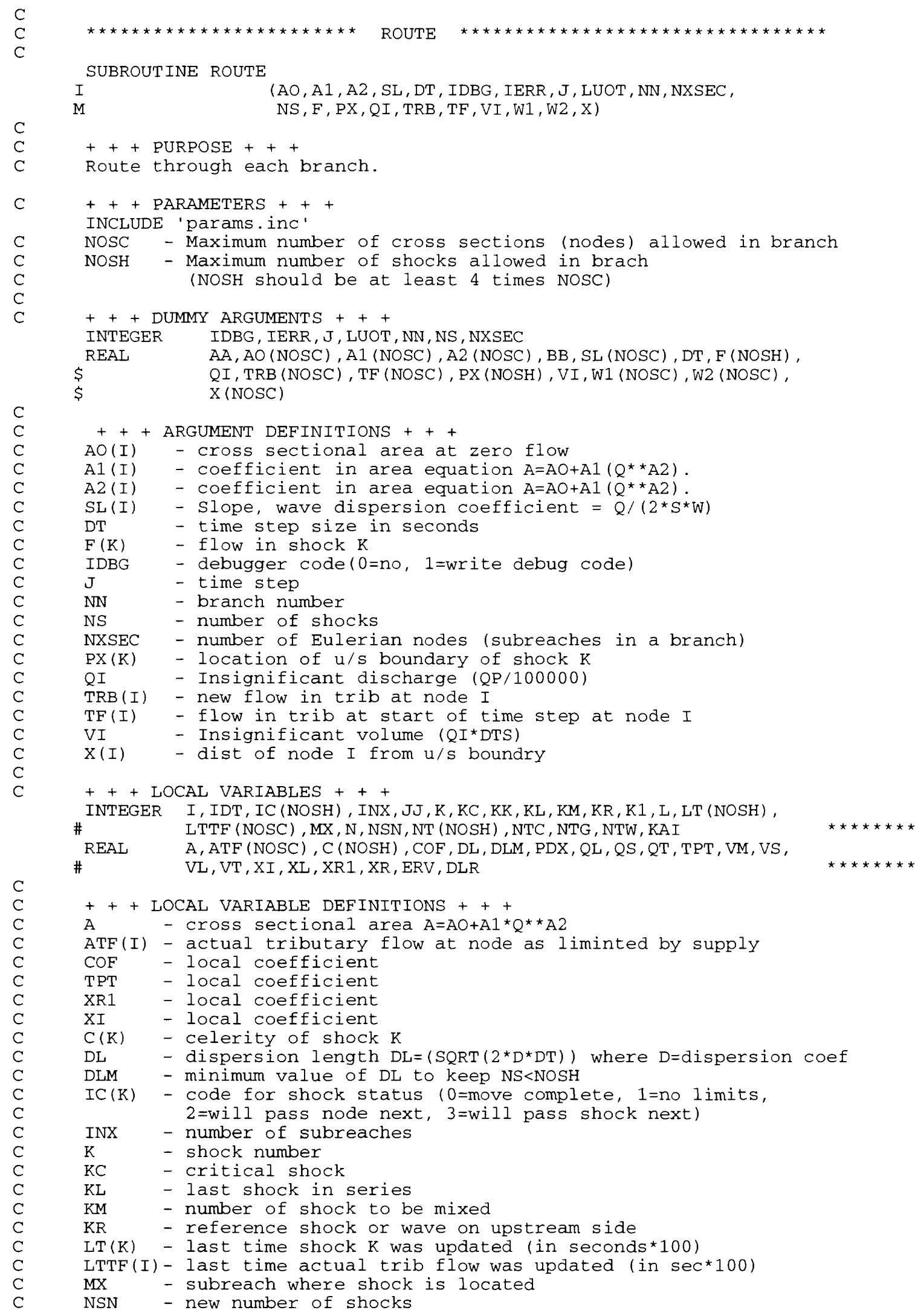




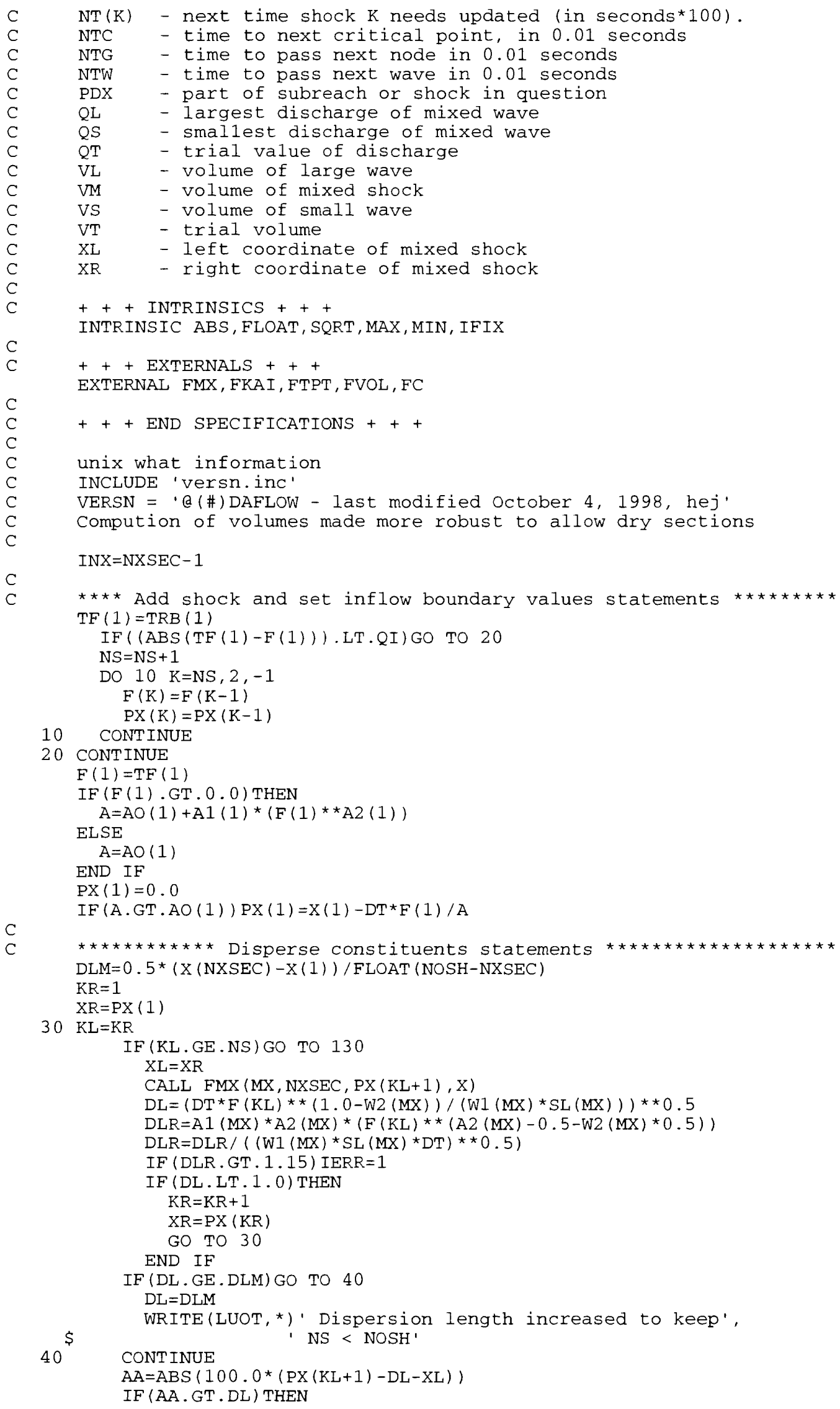




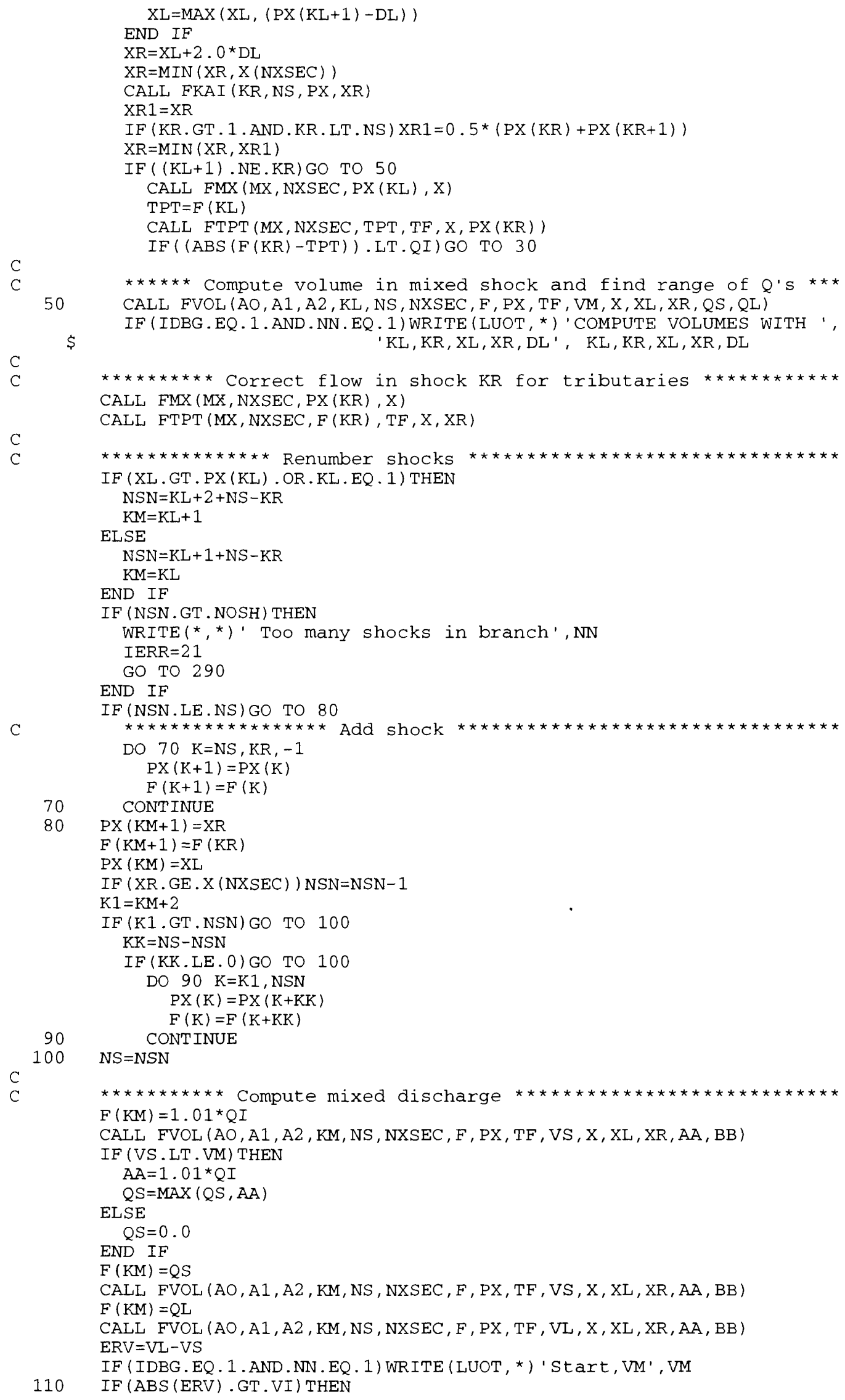


C

C

C END IF $\mathrm{KR}=\mathrm{KM}+1$ GO TO 30

130 CONTINUE

IF (PX (NS) . GE.X (NXSEC) ) NS $=$ NS -1

$\mathrm{PX}(1)=\mathrm{X}(1)$

JJ $=$ IFIX (TIME/DT+0.501)-JTS + 1

IF (IDBG.EQ.1)WRITE (LUOT, *)' AFTER MIX J,N', JJ, NN

IF (IDBG.EQ.1)WRITE (LUOT, *)' $\mathrm{PX}=$ ', (PX (K), K=1,NS)

C

IF (IDBG.EQ.I)WRITE (LUOT, *)' $F={ }^{\prime},(F(K), K=1, N S$ )

C

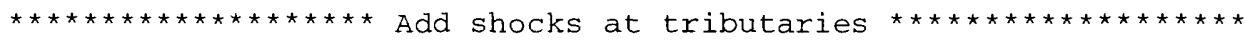
DO $160 \quad I=2$, INX

$\operatorname{LTTF}(I)=0$

$\operatorname{ATF}(I)=0.0$

IF ( (ABS (TF (I) -TRB (I) )).LT.OI) GO TO 160

CALL FKAI (K, NS, PX, X (I))

$\mathrm{A}=\mathrm{AO}(\mathrm{I})+\mathrm{A} 1(\mathrm{I}) *(\mathrm{~F}(\mathrm{~K}) * \star \mathrm{A} 2(\mathrm{I}))$

$\mathrm{XI}=0.01$

$I F(A . G T .0 .0) X I=Q I * D T / A$

IF (ABS (X) I ) -PX (K)).LT.XI) GO TO 160

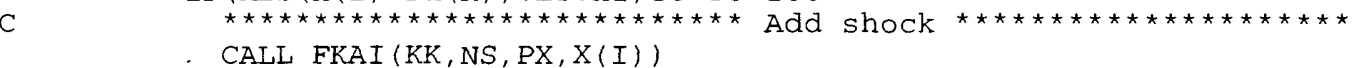
$\mathrm{NS}=\mathrm{NS}+1$

$\mathrm{K} 1=\mathrm{KK}+2$

DO $150 \mathrm{~K}=\mathrm{NS}, \mathrm{K} 1,-1$

$\mathrm{PX}(\mathrm{K})=\mathrm{PX}(\mathrm{K}-1)$

150 $F(K)=F(K-1)$

CONTINUE

$\mathrm{PX}(\mathrm{KK}+1)=\mathrm{X}(\mathrm{I})$

CALL FMX (MX, NXSEC, PX (KK), X)

$\mathrm{TPT}=\mathrm{F}(\mathrm{KK})$

CALL FTPT (MX, NXSEC, TPT, TF, X,X(I))

IF (TPT.LE . 0.0) THEN

$F(K K+1)=0.0$

ELSE

END IF

160 CONTINUE

$\mathrm{F}(\mathrm{KK}+1)=\mathrm{TPT}$

IF (IDBG.EQ.1)WRITE (LUOT, *) ' AFTER TF SHOCKS '

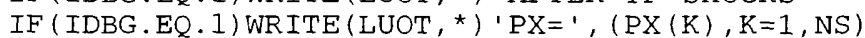

C

IF (IDBG.EQ. 1) WRITE (LUOT, *) ' $F=$ ', (F(K), $K=1, N S)$

C

DO $180 \mathrm{~K}=2, \mathrm{NS}$

CALL FC (AO, C (K), A1, A2, K, NS, NXSEC, F, PX, TRB, X, QI)

$\mathrm{LT}(\mathrm{K})=0$

180 CONTINUE

CoNt INUE 


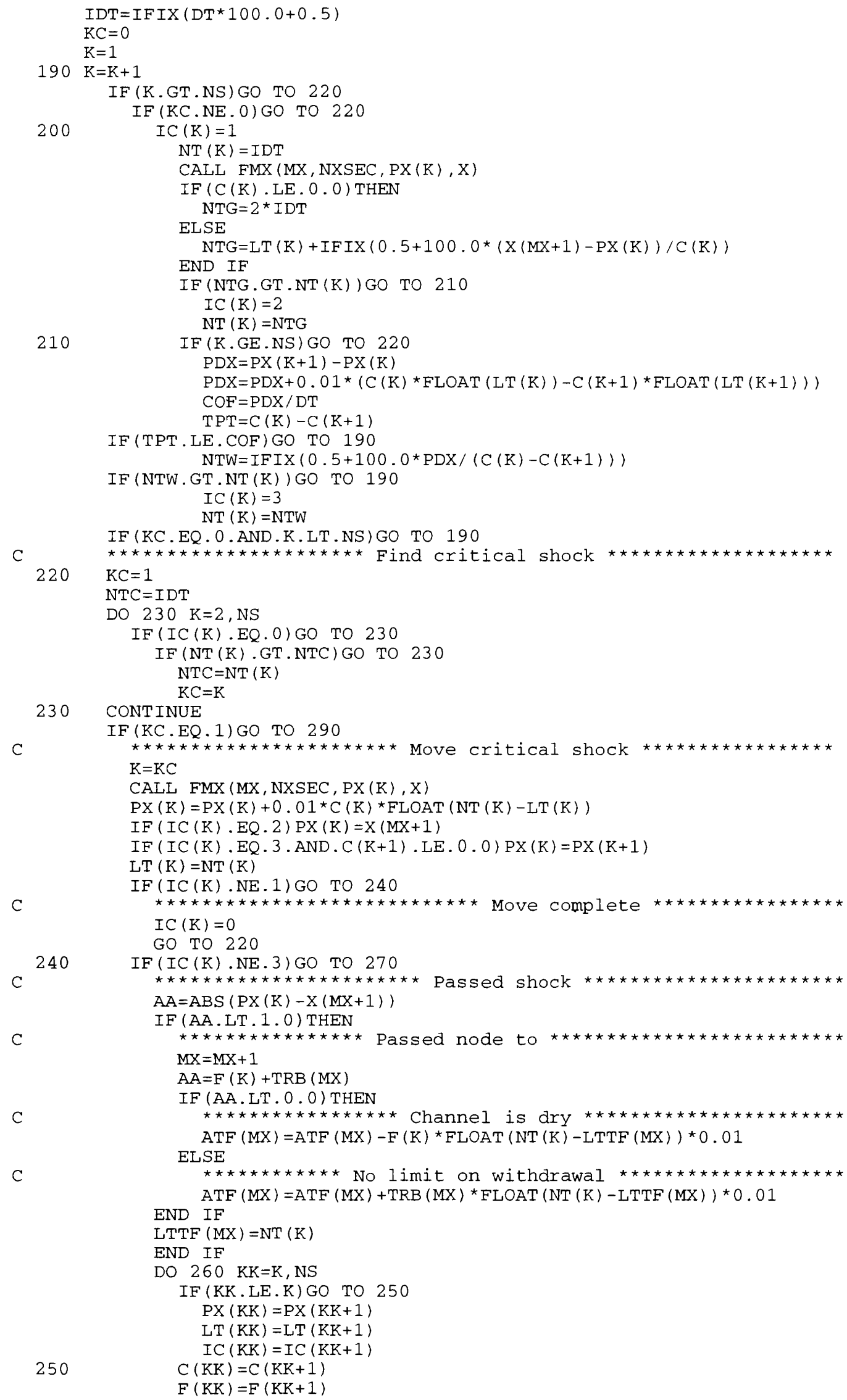









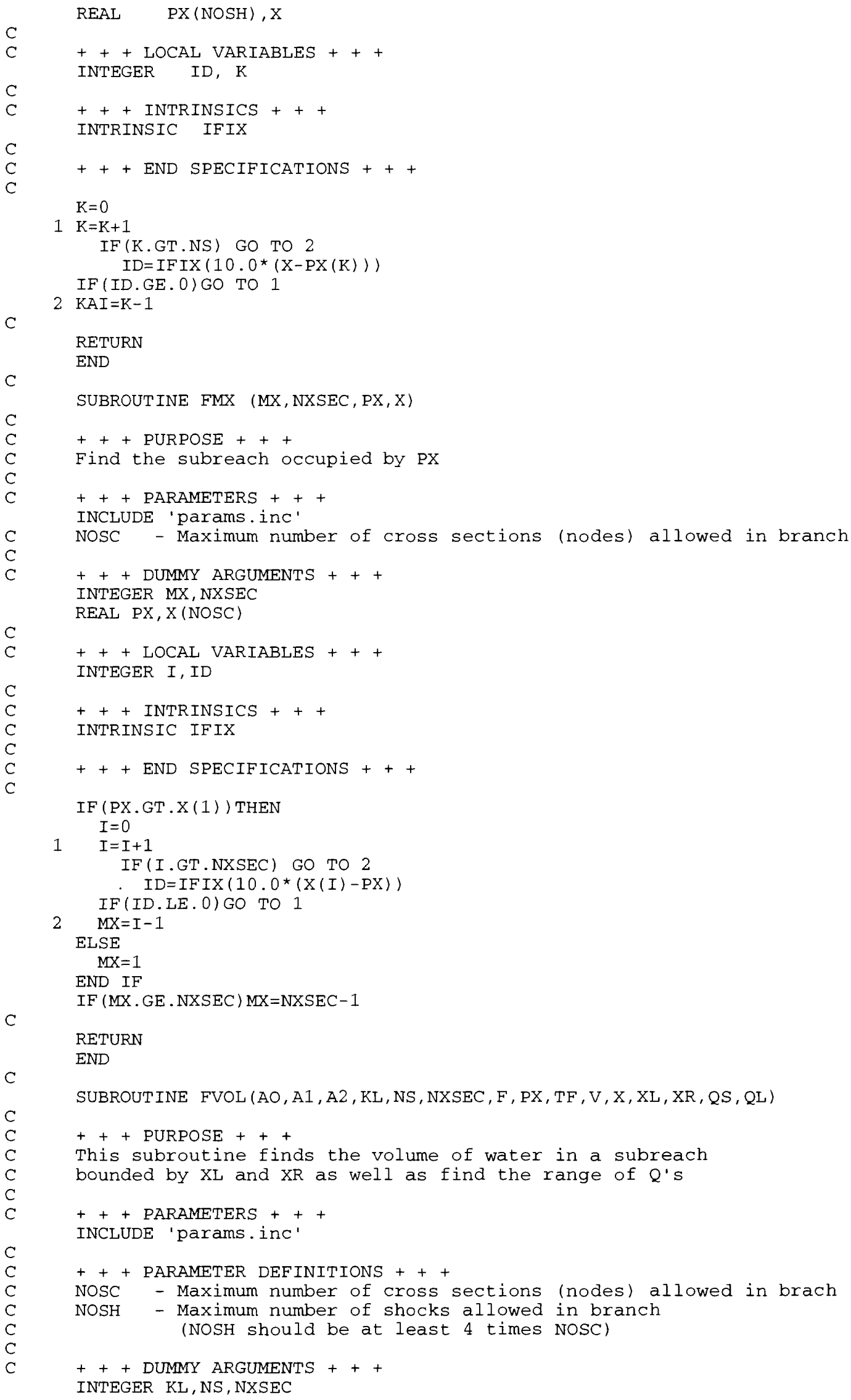


REAL AO (NOSC), A1 (NOSC), A2 (NOSC), F (NOSH), PX (NOSH), QL, QS, TF (NOSC),

C \# $\quad \mathrm{V}, \mathrm{X}(\mathrm{NOSC}), \mathrm{XL}, \mathrm{XR}$

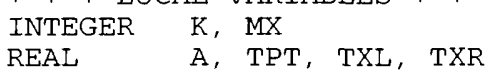

C

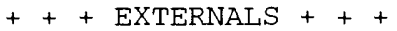

C 


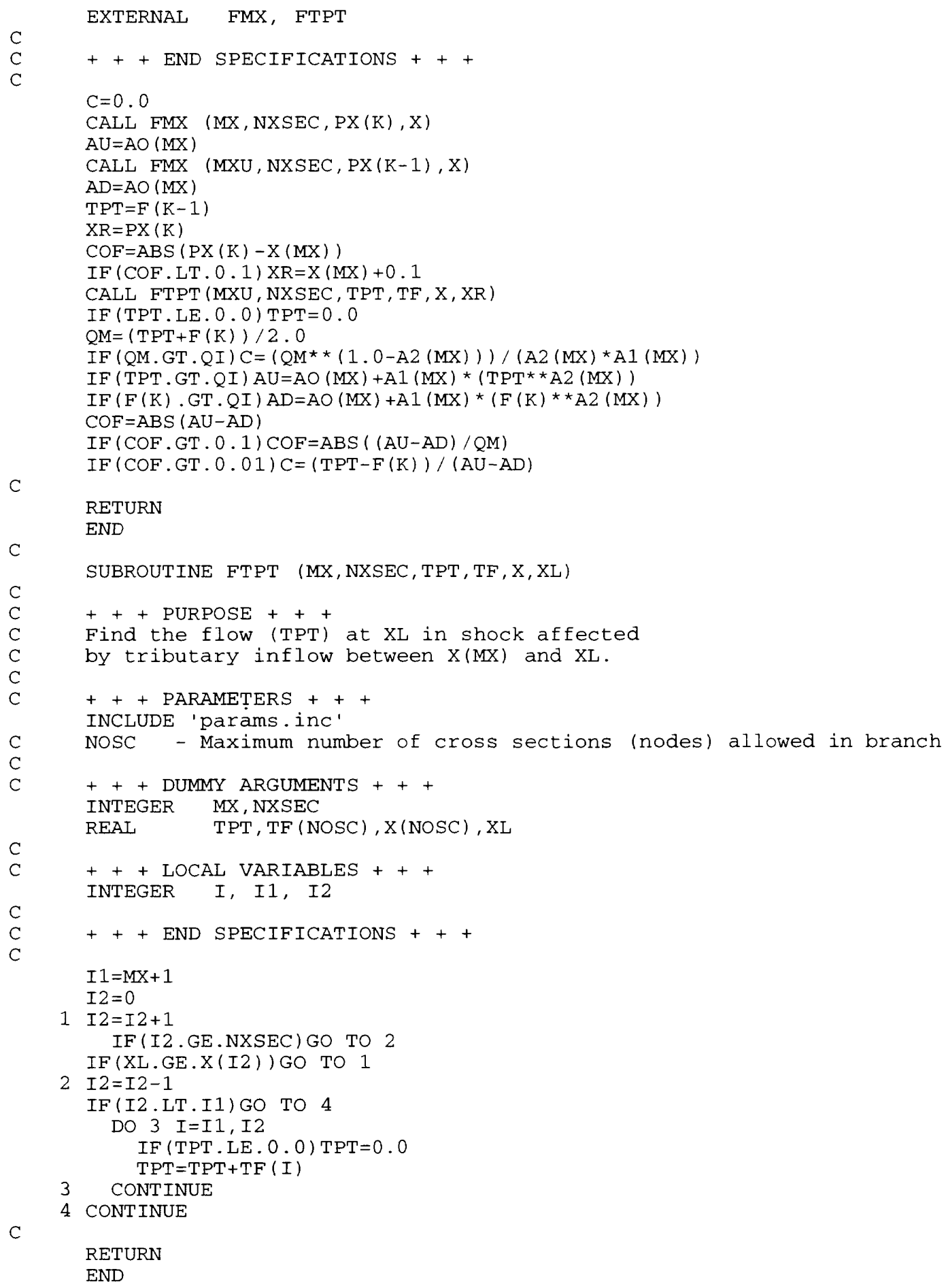




\section{Code in the file daf1.for}

C

$\mathrm{C}$

$\mathrm{C}$

$\mathrm{C}$

C

C

C

C

C

$\mathrm{C}$$$
10
$$

C

2010 FORMAT (2I6,2F10.2, G15.3, 3I6)

2020 FORMAT (' Something wrong in subroutine DAF1AL')

2030 FORMAT (1X, 'The DAFLOW ground-water file (file type DAFG) was',/ $11 \mathrm{X}$, 'not included in the name file')

2040 FORMAT (1X,' The DAFLOW output flow file (file type DAFF) was', 1

SUBROUTINE DAF1AL (IERR, LUFLW, LUGW, LUIN, LUOT, IDAFCB, IDAFBK)

Read input and do preliminary computations

INCLUDE 'params.inc'

NOBR - Maximum number of branches allowed in model

- Maximum number of cross sections (nodes) allowed in branch

年

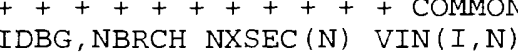

++++++++++ COMMON DEFINTIONS (ground. COm) ++++++ $\operatorname{AQGW}(I, N, J) \quad B C(I, N, J) \operatorname{BEL}(I, N) \operatorname{BTH}(I, N) \operatorname{CND}(I, N) \operatorname{NCL}(I, N) \operatorname{NLY}(I, N)$

$\operatorname{NRW}(I, N) \quad \operatorname{VGW}(I, N, J)$

++++++++++++ LOCAL ++ VARIABLES +++++++++++++ CHARACTER * 64 VERSN

CHARACTER *80 TITLE

Central vs backward differencing flag for MODFLOW

$++++++++++++\operatorname{INTRINSICS}++++++++++++++++$

$+++++++++++\operatorname{tEXTERNALS}+++++++++++++++++$ EXTERNAL STARTDAF

1X, 'not included in the name file')

C
C
C
C
C
C
C
C

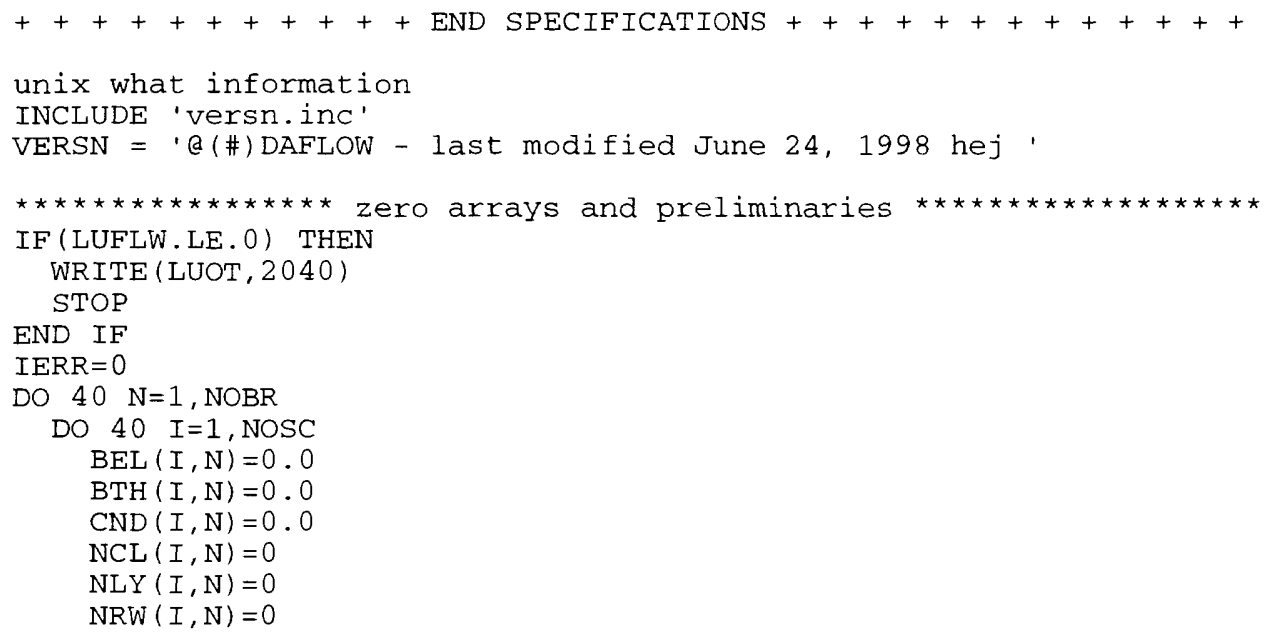




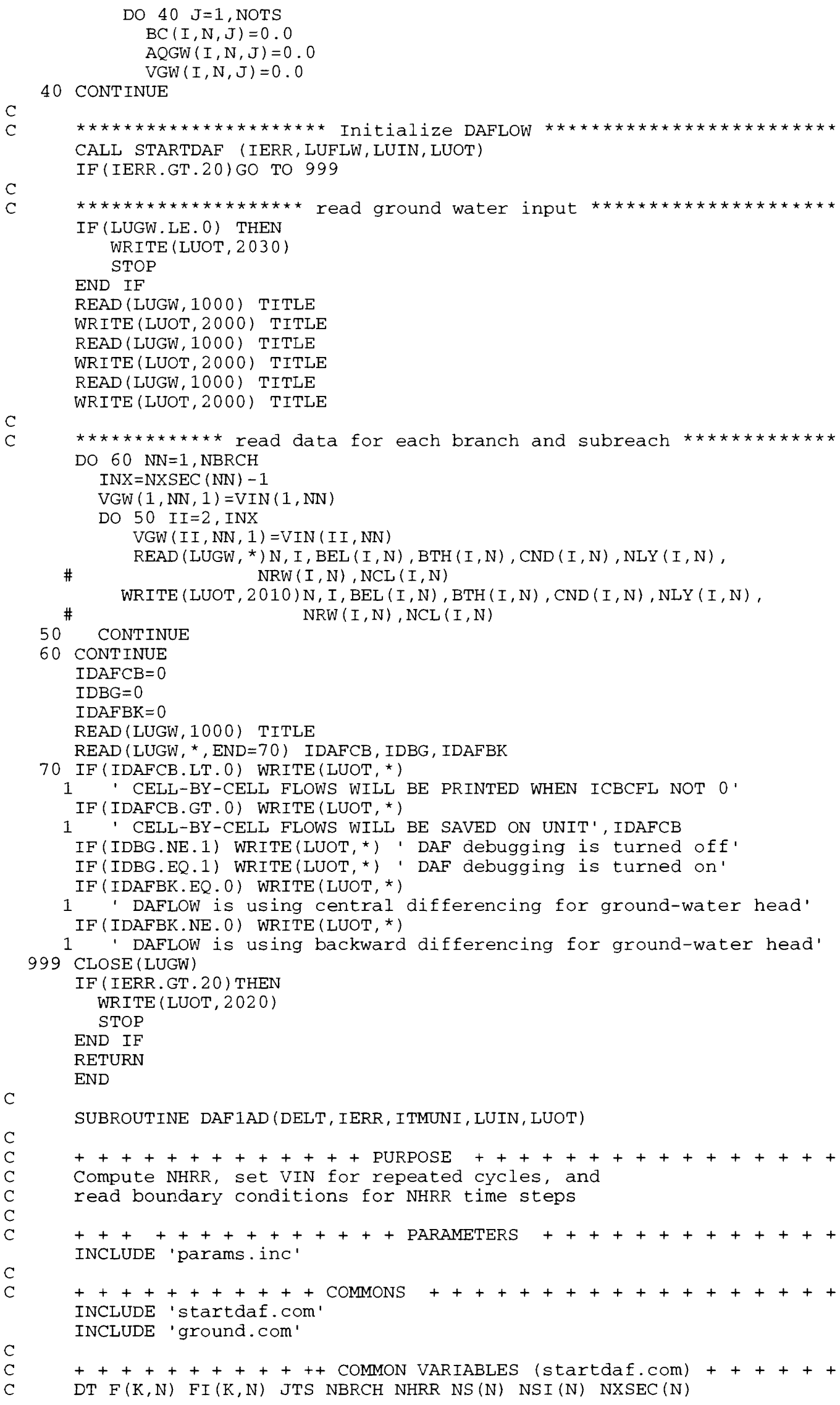


** Compute number of daflow time steps per MODFLOW time step **** $\mathrm{AA}=0.0$ 
END

C

$C$
$C$
$C$
$C$
$C$
$C$
$C$
$C$
$C$
$C$
$C$
$C$
$C$
$C$
$C$
$C$
$C$
$C$
$C$

SUBROUTINE DAF1FM （IERR, ITMUNI, HNEW, HOLD, LUOT,

IBOUND, HCOF, RHS, NCOL, NROW, NLAY, KITER, IDAFBK)

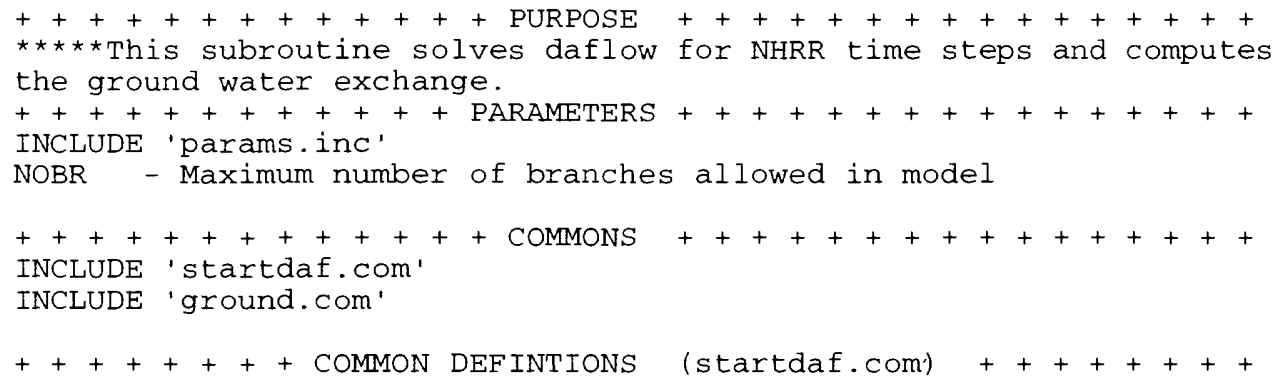




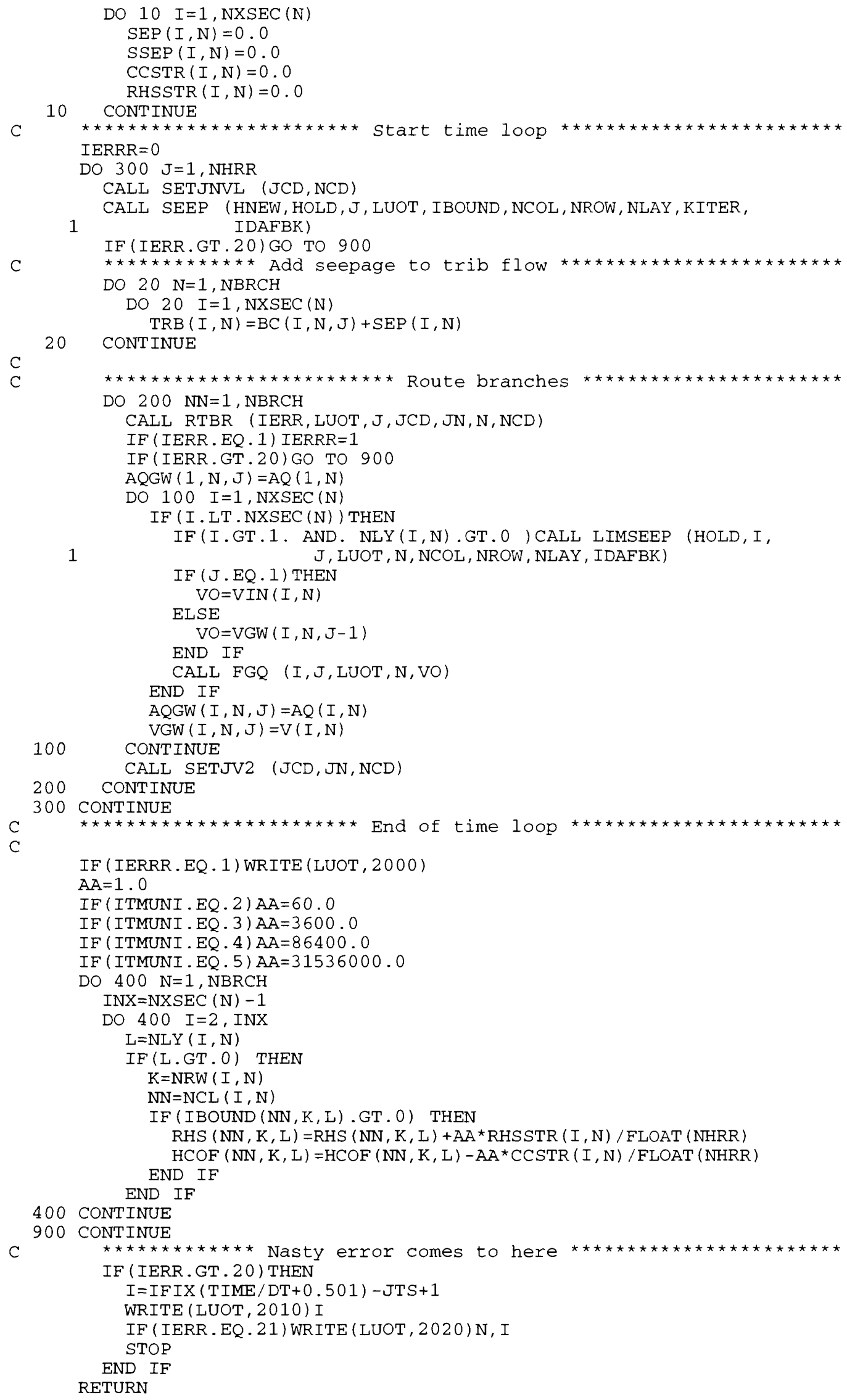


END

C

SUBROUTINE SEEP (HNEW, HOLD, J, LUOT, IBOUND, NCOL, NROW, NLAY,

C
C
C
C
C
C
C
C
C
C
C
C
C
C

KITER, IDAFBK

$+++++++++++++++\operatorname{PURPOSE}+++++++++++++++++$

$* \star \star \star \star T h i s$ subroutine computes the seepage to the channel

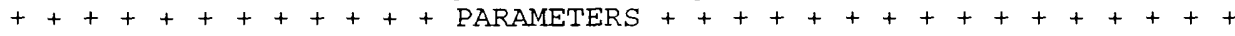

INCLUDE 'params.inc'

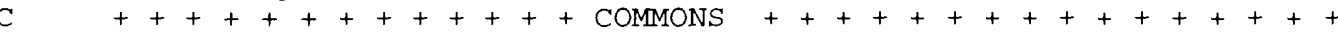

INCLUDE 'startdaf.com'

INCLUDE 'ground.com'

+++++++++ COMMON DEFINTIONS (startaaf. com) ++++++++ $\mathrm{AO}(I, N) \quad \mathrm{A} 1(\mathrm{I}, \mathrm{N})$ A2 (I,N) IDBG NBRCH NHRR NXSEC(N) $\operatorname{VIN}(I, N)$

$W 1(I, N) \quad W 2(I, N) \quad X(I, N)$

+++++++++ COMMON DEFINTIONS (ground. com) +++++++++ $\operatorname{BEL}(I, N) \quad \operatorname{BTH}(I, N) \operatorname{CND}(I, N) \operatorname{CSTR}(I, N) \quad \operatorname{NCL}(I, N) \quad \operatorname{NLY}(I, N)$

$\operatorname{NRW}(I, N) \operatorname{QSTR}(I, N) \operatorname{SEP}(I, N) \operatorname{STAGE}(I, N) \operatorname{VGW}(I, N)$

++++++++++ LOCAL VARIABLES

INTEGER I, IDAFBK, INX, J, KITER, LUOT , N

INTEGER NCOL, NROW, NLAY, IBOUND (NCOL, NROW, NLAY)

DOUBLE PRECISION HNEW (NCOL, NROW, NLAY)

REAL A, AA, AR, DPT, HD, HOLD (NCOL, NROW, NLAY), Q, W CHARACTER * 64 VERSN

++++++++++++ LOCAL DEFINITIONS ++++++++++++++

A Cross sectional area of flow in subreach

AR Surface area of water in subreach

DPT Depth of flow (A/W)

HNEW (M, N,L) Ground water head at end of time ste in cell M,N,L

HD Head, either water surface elev or seepage head

HOLD (M, N, L) Ground water head at start of time step in cell M, N, L

IDAFBK Central vs backward differencing flag for MODFLOW

J Time step

W Top with of water surface in subreach

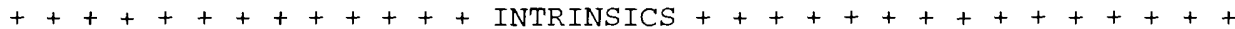
INTRINSIC FLOAT

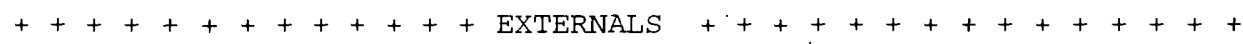

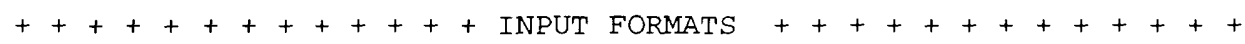

$+++++++++++++++\operatorname{OUTPUT}$ FORMATS ++++++++++++++

2000 FORMAT(' For time step ', I5,', branch ', I3,

$\#$ ' The requested seepage $=$ ')

2010 FORMAT (10G11.4)

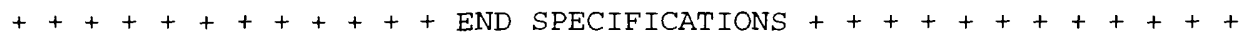

unix what information

INCLUDE 'versn. inc'

VERSN = ' a (\#) DAFLOW - coded by hej June 2,1997'

DO $20 \mathrm{~N}=1, \mathrm{NBRCH}$

$\operatorname{INX}=\operatorname{NXSEC}(\mathrm{N})-2$

DO $10 \quad I=1, I N X$

$\operatorname{SEP}(I+1, N)=0$.

$\operatorname{QSTR}(I+1, N)=0$.

$\operatorname{STAGE}(I+1, N)=0$.

$\operatorname{CSTR}(I+1, N)=0$.

$\operatorname{IF}(\mathrm{NLY}(I+1, N)$.GT.0) THEN

C

$\operatorname{IF}(\operatorname{IBOUND}(\mathrm{NCL}(I+1, N), \operatorname{NRW}(I+1, N), \operatorname{NLY}(I+1, N)) . \operatorname{NE} .0)$ THEN

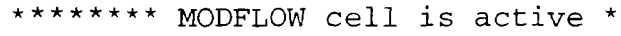
IF (KITER.EQ. 1) THEN

IF (J.EQ.1) THEN

$A=\operatorname{VIN}(I, N) /(X(I+1, N)-X(I, N))$

ELSE 
C

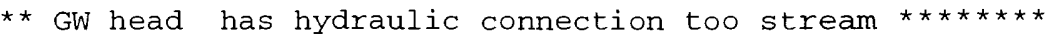
IF (DPT.LE.0.0 .AND. HD.LE.0.0) THEN

$\operatorname{SEP}(I+1, N)=0.0$

$\operatorname{STAGE}(I+1, N)=0.0$ $\operatorname{CSTR}(I+1, N)=0.0$

'Width, Area based on gw head', W1 $(I, N){ }^{*} A A^{*}{ }^{*} W 2(I, N), A R$ 
CONTINUE

IF (IDBG.EQ . 1)WRITE (LUOT, 2000) J, N

INX $=$ NXSEC $(\mathrm{N})-1$

20 CONTINUE

IF (IDBG .EQ.1) WRITE (LUOT, 2010) ( $\operatorname{SEP}(I, N), I=2, I N X)$

C

RETURN

C

END

SUBROUTINE LIMSEEP (HOLD, I, J , LUOT, N, NCOL, NROW, NLAY, IDAFBK)

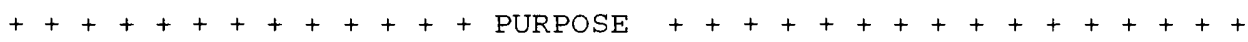

$\star \star \star$ This subroutine apportions any increase in TRB (reduction in

*** outflow from the stream) that is calculated by ROUTE between

$\star \star \star B C$ and SEP. Negative BC values are increased to 0 prior to

*** increasing negative SEP values. Coefficients SSEP, RHSSTR,

$\star \star \star \&$ CCSTR are also set.

++++++++++++ PARAMETERS +++++++++++++++ INCLUDE 'params. inC'

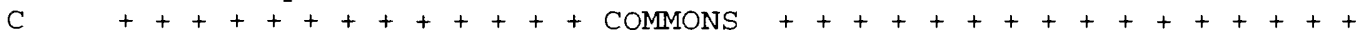
INCLUDE 'startdaf.com'

INCLUDE 'ground.com'

C

++++++++ COMMON DEFINTIONS (startdaf.com) ++++++++ DT JTS QI IDBG NHRR TIME TRB $(I, N)$

++++++++ COMMON DEFINTIONS (ground. COm) +++++++++ $\operatorname{BC}(I, N, J) \quad \operatorname{CCSTR}(I, N) \quad \operatorname{CSTR}(I, N) \quad \operatorname{NCL}(I, N) \quad \operatorname{NLY}(I, N) \quad N R W(I, N)$

$\operatorname{QSTR}(I, N) \operatorname{RHSSTR}(I, N) \operatorname{SEP}(I, N) \operatorname{SSEP}(I, N) \operatorname{STAGE}(I, N)$

++++++++++ LOCAL VARIABLES +++++++++++++++ INTEGER I, IDAFBK, J, JJ, LUOT, N, NCOL, NROW, NLAY

REAL AA, BCNEW, HOLD (NCOL, NROW, NLAY), TRBOLD, TRBCHG

C

+++++++++++ LOCAL DEFINITIONS +++++++++++++

BCNEW - Adjusted value of withdrawal caused by lack of water

HOLD (M, N, L) Ground water head at start of time step in cell M,N,L

IDAFBK - Central vs backward differencing flag for MODFLOW

$\mathrm{N} \quad-$ Branch number

NCOL - Number of columns in ground-water model

NLAY - Number of layers in ground-water model

NROW - Number of rows in ground-water model

$\mathrm{J}$ - Time step number

TRBOLD - Value of TRB that was sent to ROUTE (BC+SEP).

TRBCHG - Reduction necessary in the extraction

$+++++++++++++\operatorname{tNTRINSICS~}++++++++++++++$

INTRINSIC FLOAT, IFIX

$+++++++++++++\operatorname{EXTERNALS}+++++++++++++++$

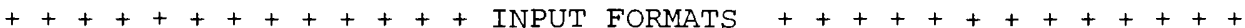

+++++++++++++ OUTPUT FORMATS +++++++++++++

4030 FORMAT(' Channel dry, reduced BC withdrawal to',G12.3,

$\$$ 'at time step', I6,' Branch', I4,' Node', I4)

4040 FORMAT(' Channel dry, limited GW seepage to',G12.3

$\$$ ' at time step',I6,' Branch', I4,' Node', I4

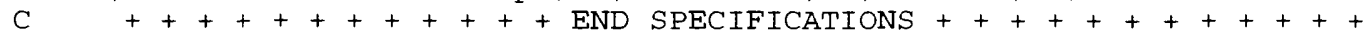

JJ $=$ IFIX $(T I M E / D T+0.501)-J T S+1$

$\operatorname{TRBOLD}=\operatorname{SEP}(I, N)+B C(I, N, J)$

C $\star \star \star$ ROUTE will have modified TRB only when TRBOLD is negative. *** IF (TRBOLD.LT.0.0) THEN TRBCHG $=T R B(I, N)-T R B O L D$

C * Apportion change in TRB only if there was a significant change IF (TRBCHG.GT. $-1 . E-6 *$ TRBOLD) THEN $\operatorname{IF}(B C(I, N, J) . L T .0)$ THEN

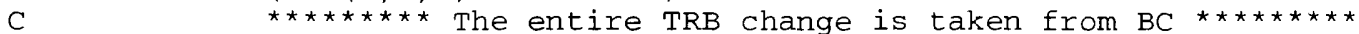
$\mathrm{BCNEW}=\mathrm{BC}(\mathrm{I}, \mathrm{N}, \mathrm{J})+\mathrm{TRBCHG}$ IF (IDBG.EQ.1) WRITE (LUOT, 4030) BCNEW, J, N, I ** Part of TRB change is taken from SEP and part from BC * 
IF (IDBG.EQ.1) WRITE(LUOT, 4030) 0 , , J, N, I $\operatorname{SEP}(I, N)=\operatorname{SEP}(I, N)+B C(I, N, J)+T R B C H G$

$\operatorname{QSTR}(I, N)=\operatorname{SEP}(I, N)$

$\operatorname{CSTR}(I, N)=0.0$

$\operatorname{STAGE}(I, N)=0.0$

IF (IDBG.EQ.1) WRITE (LUOT, 4040) SEP(I,N) , JJ, N, I ELSE END IF 


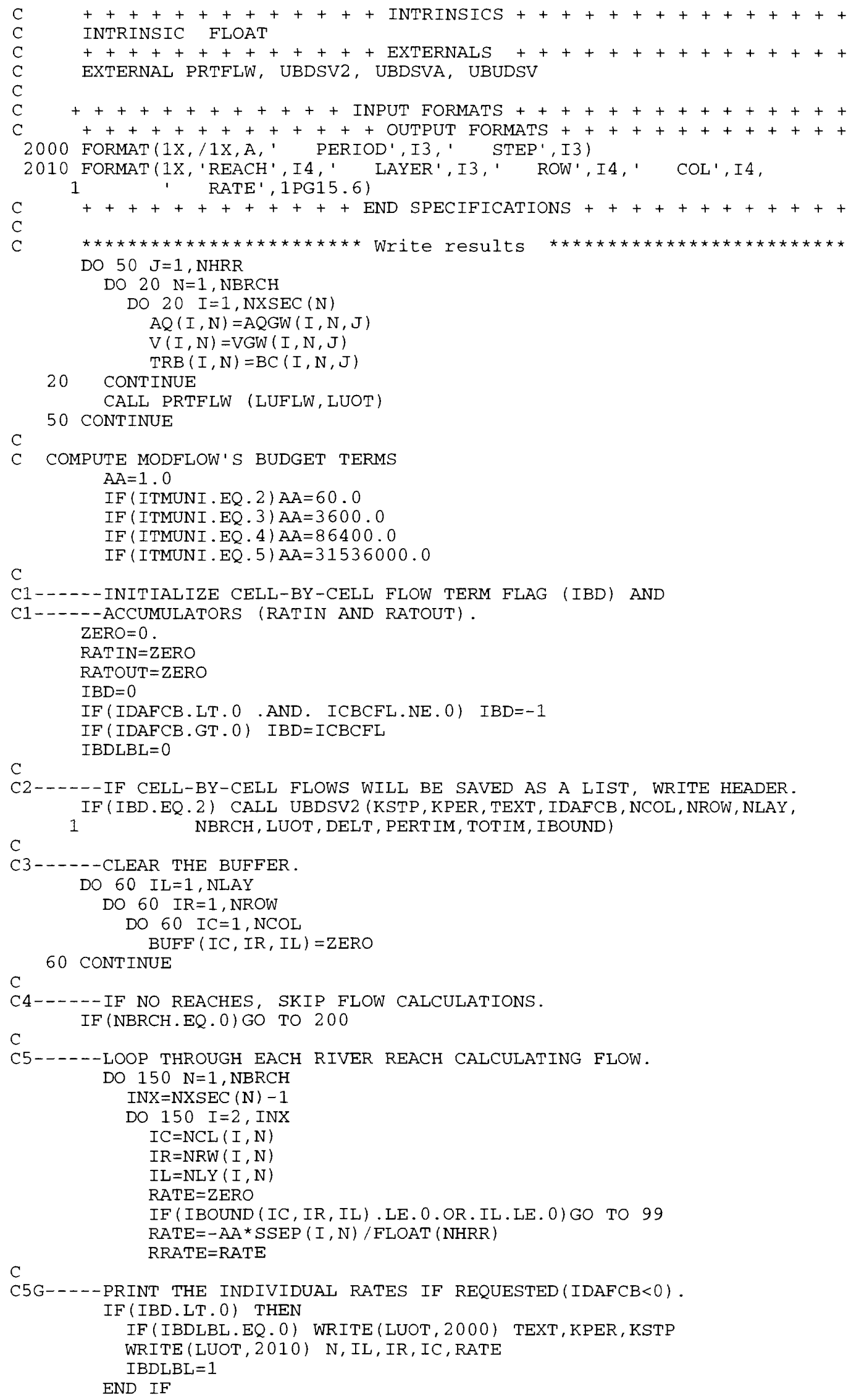


C

C5H-----ADD RATE TO BUFFER.

$\operatorname{BUFF}(I C, I R, I L)=B U F F(I C, I R, I L)+R A T E$

C

C5I----SEE IF FLOW IS INTO AQUIFER OR INTO RIVER.

C IF (RATE) $94,99,96$

C5J-----AQUIFER IS DISCHARGING TO RIVER SUBTRACT RATE FROM RATOUT.

94 RATOUT=RATOUT-RRATE

GO TO 99

$\mathrm{C}$

C5K-----AQUIFER IS RECHARGED FROM RIVER; ADD RATE TO RATIN.

96 RATIN=RATIN+RRATE

C

C5L----IF SAVING CELL-BY-CELL FLOWS IN LIST, WRITE FLOW.

99 IF (IBD.EQ.2) CALL UBDSVA ( IDAFCB, NCOL, NROW, IC, IR, IL, RATE, IBOUND,

1 NLAY)

C

150 CONTINUE

C6-.--IF CELL-BY-CELL FLOW WILL BE SAVED AS A 3-D ARRAY,

C6-..-- CALL UBUDSV TO SAVE THEM.

IF (IBD. EQ.1) CALL UBUDSV (KSTP, KPER, TEXT, IDAFCB, BUFF , NCOL, NROW,

1

NLAY, LUOT)

C

C7--.--MOVE RATES, VOLUMES \& LABELS INTO ARRAYS FOR PRINTING.

200 RIN=RATIN

ROUT $=$ RATOUT

$\operatorname{VBVL}(3$, MSUM $)=$ RIN

VBVL $(4$, MSUM $)=$ ROUT

$\operatorname{VBVL}(1, M S U M)=\operatorname{VBVL}(1$, MSUM $)+\operatorname{RIN}^{*} \operatorname{DELT}$

$\operatorname{VBVL}(2$, MSUM $)=\operatorname{VBVL}(2$, MSUM $)+$ ROUT $*$ DELT

C VBNM $($ MSUM $)=$ TEXT

C8--.--INCREMENT BUDGET TERM COUNTER.

MSUM $=$ MSUM +1

RETURN

END 


\title{
Parameter definition file, params.inc
}

\author{
INTEGER NOBR, NOSC, NOSH, NOCO, NOPR, NOCP, NOTS \\ $\mathrm{C}$ \\ PARAMETER (NOBR $=5, \quad$ NOSC $=35, \quad$ NOSH $=200, \quad N O C O=10)$ \\ PARAMETER $\quad($ NOPR $=150, \mathrm{NOCP}=4000, \quad \mathrm{NOTS}=20)$ \\ C
C
C
C \\ +++ PARAMETER DEFINITIONS + + + \\ NOBR - Maximum number of branches allowed in model \\ NOSC - Maximum number of cross sections (nodes) allowed in branch \\ NOSH - Maximum number of shocks allowed in branch \\ (NOSH should be at least 4 times NOSC) \\ NOCO - Maximum number of constituents allowed \\ NOPR - Maximum number of parcels allowed in branch \\ (NOPR should be at least $20+2$ times NOSC) \\ NOCP - Maximum number of computed or observed points \\ NOTS - Maximum of time steps per ground water step
}

\section{Common block include file, startdaf.com}

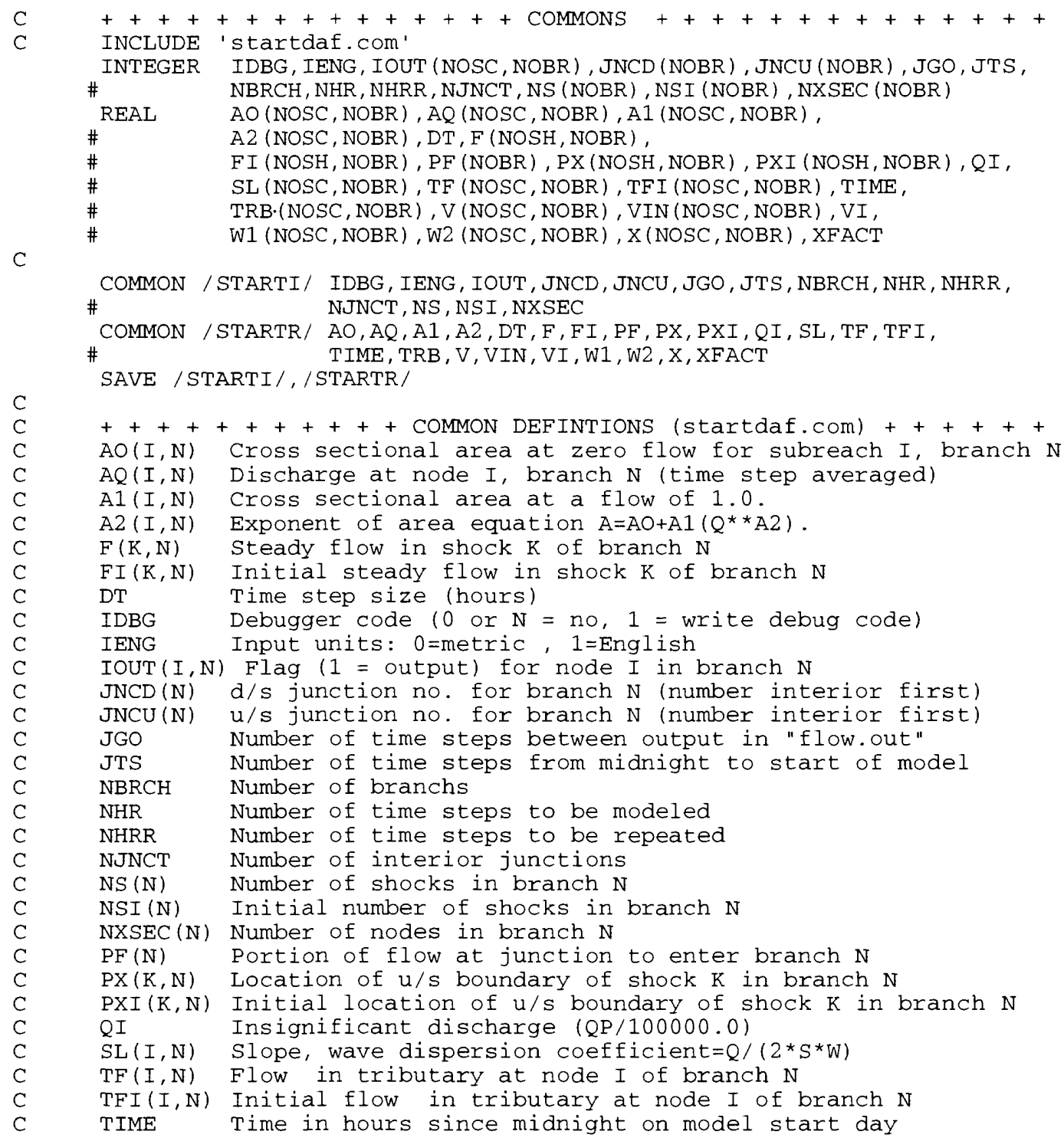


$\operatorname{TRB}(I, N)$ New flow in tributary at node $I$ of branch $N$

$V(I, N)$ Volume of water in subreach $I$, of branch $\mathrm{N}$

$\operatorname{VIN}(I, N)$ Initial volume of water in subreach $I$ of branch $N$

VI Insignificant volume ( $Q I^{\star} D T$, in seconds)

$W I(I, N)$ Coefficient in $W=W 1(Q) * * W 2$ for subreach $I$ branch $N$

$W 2(I, N)$ Coefficient in $W=W 1(Q) * * W 2$ for subreach I branch $N$

$\mathrm{X}(\mathrm{I}, \mathrm{N})$ Distance of node $\mathrm{I}$ in branch $\mathrm{N}$ downstream of reference point

XFACT Conversion from miles to feet or meters, depending on IENG

\section{Common block include file, ground.com}

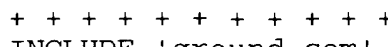




\title{
APPENDIX B. MODFLOW DATA FILES FOR EXAMPLE 1 SIMULATION
}

MODFLOW name file for Example 1 simulation:

\author{
$\begin{array}{llllllll}1 & 2 & 3 & 4 & 5 & 6 & 7 & 8\end{array}$ \\ 12345678901234567890123456789012345678901234567890123456789012345678901234567890 \\ LIST 8 example1.1st \\ BAS 9 example1.bas \\ BCF 11 example1.bcf \\ RCH 18 examplel.rch \\ SIP 19 example1.sip \\ OC 22 example1.oC \\ DAF 31 example1.inf \\ DAFG 32 example1.ing \\ DAFF 90 bltm.flw
}

MODFLOW Basic Package file, example1.bas:

\begin{tabular}{cccccc}
1 & 2 & 4 & 5 & 7 & 8 \\
12345678901234567890123456789012345678901234567890123456789012345678901234567890 \\
\hline
\end{tabular} TEST PROBLEM 1--CONSTANT STREAM STAGE AND VARIABLE RECHARGE TO AQUIFER

\begin{tabular}{|c|c|c|c|c|c|c|c|c|c|}
\hline \multirow{2}{*}{ ptions } & 1 & 13 & 39 & 144 & & \multicolumn{4}{|l|}{1} \\
\hline & 0 & 1 & & & & & & & \\
\hline ONSTANT & 1 & & & & & & & & \\
\hline 995 & & & & & & & & & \\
\hline NTERNAL & 1.0 & 8.01 & 16 & & & & & & \\
\hline 58.346 & 58.258 & 58.132 & 57.955 & 57.730 & 57.459 & 57.138 & 56.775 & 56.370 & 55.926 \\
\hline 55.445 & 54.930 & 54.384 & 53.810 & 53.213 & 52.595 & 51.961 & 51.314 & 50.659 & 50.000 \\
\hline 50.659 & 51.314 & 51.961 & 52.595 & 53.213 & 53.810 & 54.384 & 54.930 & 55.445 & 55.926 \\
\hline 56.370 & 56.775 & 57.138 & 57.459 & 57.730 & 57.955 & 58.132 & 58.258 & 58.346 & \\
\hline 58.346 & 58.258 & 58.132 & 57.955 & 57.730 & 57.459 & 57.138 & 56.775 & 56.370 & 55.926 \\
\hline 55.445 & 54.930 & 54.384 & 53.810 & 53.213 & 52.595 & 51.961 & 51.314 & 50.659 & 50.000 \\
\hline 50.659 & 51.314 & 51.961 & 52.595 & 53.213 & 53.810 & 54.384 & 54.930 & 55.445 & 55.926 \\
\hline 70 & 56.775 & 57.138 & 57.459 & 57.730 & 57.955 & 58.132 & 58.258 & 58.346 & \\
\hline 58.346 & 58.258 & 58.132 & 57.955 & 57.730 & 57.459 & 57.138 & 56.7 & 56.370 & 55.926 \\
\hline 55.445 & 54.930 & 54.384 & 53.810 & 53.213 & 52.5 & 51.961 & 51.3 & 50.6 & 5 \\
\hline 50.659 & 51.314 & 51.961 & 52.595 & 53.213 & 53.810 & 54.384 & 54.9 & 55.445 & 55.926 \\
\hline .370 & 56.775 & 57.138 & 57.459 & 57.730 & 57.955 & 58.132 & 58.2 & 58.3 & \\
\hline 346 & 58.258 & 58.132 & 57.955 & 57.730 & 57.459 & 57.138 & 56.775 & 56.370 & 55.926 \\
\hline .445 & 54.930 & 54.384 & 53.810 & 53.213 & 52.595 & 51.961 & 51.314 & 50.659 & 50.000 \\
\hline 659 & 51.314 & 51.961 & 52.595 & 53.213 & 53.810 & 54.384 & 54.9 & 55.445 & 55.926 \\
\hline 370 & 56.775 & 57.138 & 57.459 & 57.730 & 57.955 & 58.132 & 58.258 & 58.346 & \\
\hline 346 & 58.258 & 58.132 & 57.955 & 57.730 & 57.459 & 57.138 & 56.775 & 56.370 & 55.926 \\
\hline .445 & 54.930 & 54.384 & 53.810 & 53.213 & 52.595 & 51.96 & 51.3 & 50.659 & \\
\hline & 51.314 & 51.961 & 52.595 & 53.213 & 53.810 & 54.384 & 54.930 & 55.445 & 55.926 \\
\hline & 6.775 & 57.138 & 57.459 & 57.730 & 57.955 & 58.132 & 58.258 & 58.346 & \\
\hline & 58.258 & 58.132 & 57.955 & 57.730 & 57.459 & 57.138 & 56.775 & 56.370 & 6 \\
\hline & 54.930 & 54.384 & 53.810 & 53.213 & 52.595 & 51.961 & 51.314 & 50.659 & \\
\hline 50.659 & 51.314 & 51.961 & 52.595 & 53.213 & 53.810 & 54.384 & 54.9 & 55.445 & 55.926 \\
\hline & 56.775 & 57.138 & 57.459 & 57.730 & 57.9 & 58.132 & 58.2 & 58.346 & \\
\hline & 58.258 & 58.132 & 57.955 & 57.730 & 57.459 & 57.138 & 56.775 & 56.370 & 55. \\
\hline & 54.930 & 54.384 & 53.810 & 53.213 & 52.5 & 51.961 & 51.3 & 50.659 & \\
\hline & 51.31 & 51.961 & 52.595 & 53.21 & 53.8 & 54.3 & 54.9 & 55.445 & 55.926 \\
\hline & 56.775 & 57.138 & 57.459 & 57.730 & 57.955 & 58.132 & 58.258 & 58.346 & \\
\hline
\end{tabular}




$\begin{array}{llllllllll}58.346 & 58.258 & 58.132 & 57.955 & 57.730 & 57.459 & 57.138 & 56.775 & 56.370 & 55.926 \\ 55.445 & 54.930 & 54.384 & 53.810 & 53.213 & 52.595 & 51.961 & 51.314 & 50.659 & 50.000 \\ 50.659 & 51.314 & 51.961 & 52.595 & 53.213 & 53.810 & 54.384 & 54.930 & 55.445 & 55.926 \\ 56.370 & 56.775 & 57.138 & 57.459 & 57.730 & 57.955 & 58.132 & 58.258 & 58.346 & \\ 58.346 & 58.258 & 58.132 & 57.955 & 57.730 & 57.459 & 57.138 & 56.775 & 56.370 & 55.926 \\ 55.445 & 54.930 & 54.384 & 53.810 & 53.213 & 52.595 & 51.961 & 51.314 & 50.659 & 50.000 \\ 50.659 & 51.314 & 51.961 & 52.595 & 53.213 & 53.810 & 54.384 & 54.930 & 55.445 & 55.926 \\ 56.370 & 56.775 & 57.138 & 57.459 & 57.730 & 57.955 & 58.132 & 58.258 & 58.346 & \\ 58.346 & 58.258 & 58.132 & 57.955 & 57.730 & 57.459 & 57.138 & 56.775 & 56.370 & 55.926 \\ 55.445 & 54.930 & 54.384 & 53.810 & 53.213 & 52.595 & 51.961 & 51.314 & 50.659 & 50.000 \\ 50.659 & 51.314 & 51.961 & 52.595 & 53.213 & 53.810 & 54.384 & 54.930 & 55.445 & 55.926 \\ 56.370 & 56.775 & 57.138 & 57.459 & 57.730 & 57.955 & 58.132 & 58.258 & 58.346 & \\ 58.346 & 58.258 & 58.132 & 57.955 & 57.730 & 57.459 & 57.138 & 56.775 & 56.370 & 55.926 \\ 55.445 & 54.930 & 54.384 & 53.810 & 53.213 & 52.595 & 51.961 & 51.314 & 50.659 & 50.000 \\ 50.659 & 51.314 & 51.961 & 52.595 & 53.213 & 53.810 & 54.384 & 54.930 & 55.445 & 55.926 \\ 56.370 & 56.775 & 57.138 & 57.459 & 57.730 & 57.955 & 58.132 & 58.258 & 58.346 & \\ 58.346 & 58.258 & 58.132 & 57.955 & 57.730 & 57.459 & 57.138 & 56.775 & 56.370 & 55.926 \\ 55.445 & 54.930 & 54.384 & 53.810 & 53.213 & 52.595 & 51.961 & 51.314 & 50.659 & 50.000 \\ 50.659 & 51.314 & 51.961 & 52.595 & 53.213 & 53.810 & 54.384 & 54.930 & 55.445 & 55.926 \\ 56.370 & 56.775 & 57.138 & 57.459 & 57.730 & 57.955 & 58.132 & 58.258 & 58.346 & \\ 58.346 & 58.258 & 58.132 & 57.955 & 57.730 & 57.459 & 57.138 & 56.775 & 56.370 & 55.926 \\ 55.445 & 54.930 & 54.384 & 53.810 & 53.213 & 52.595 & 51.961 & 51.314 & 50.659 & 50.000 \\ 50.659 & 51.314 & 51.961 & 52.595 & 53.213 & 53.810 & 54.384 & 54.930 & 55.445 & 55.926 \\ 56.370 & 56.775 & 57.138 & 57.459 & 57.730 & 57.955 & 58.132 & 58.258 & 58.346 & \\ 1296000 . & & 2 & 1.0 & & & & & & \end{array}$

[Repeat the previous line an additional 143 times.]

MODFLOW Block-Centered Flow Package file, example1.bcf:

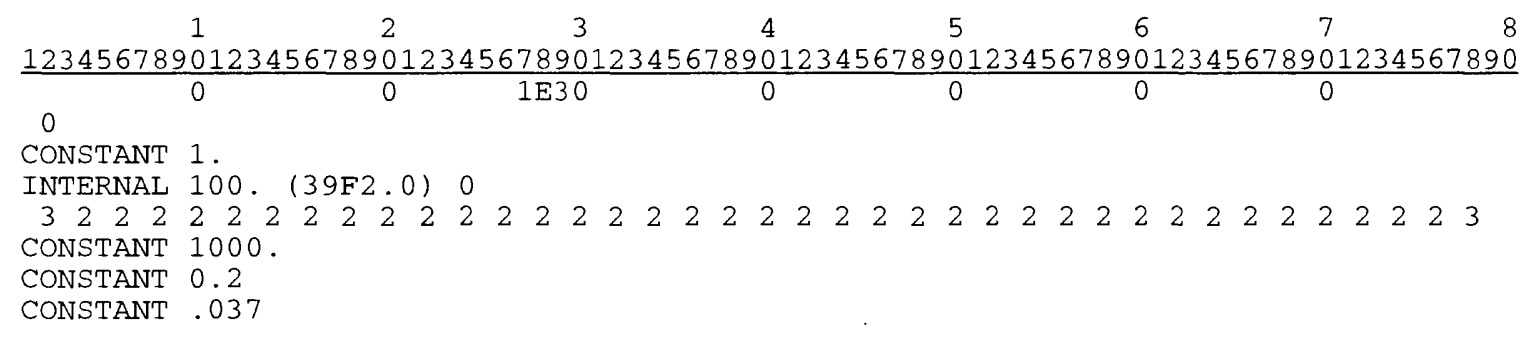

MODFLOW Recharge Package file, example l.rch:

$\frac{1}{12345678901234567890123456789012345678901234567890123456789012345678901234567890}$

CONSTANT $3.2865 \mathrm{E}-09$

1

CONSTANT $2.8250 E-08$

1

CONSTANT $7.1487 \mathrm{E}-08$

CONSTANT $1.2141 \mathrm{E}-07$

CONSTANT $1.6465 \mathrm{E}-07$

CONSTANT $1.8961 \mathrm{E}-07$

CONSTANT $1.8961 \mathrm{E}-07$ 


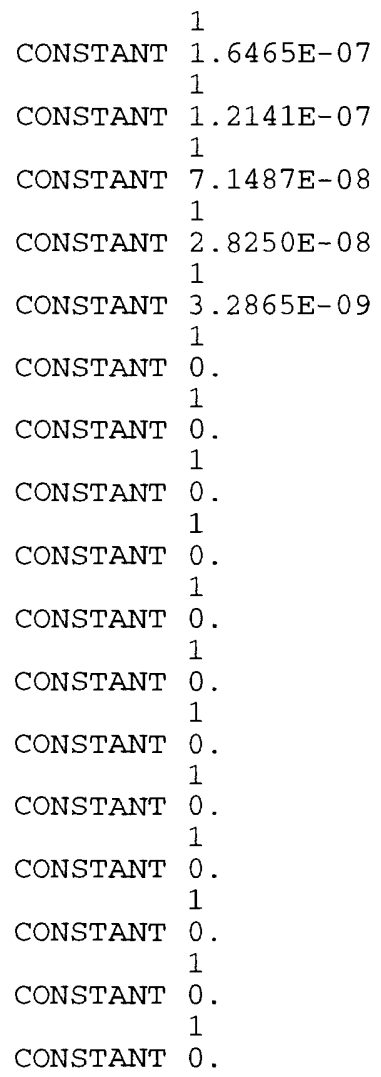

[Repeat previous 48 lines five additional times - each set of 48 lines covers 24 stress periods.]

MODFLOW Strongly-Implicit Procedure Package file, example1.sip:

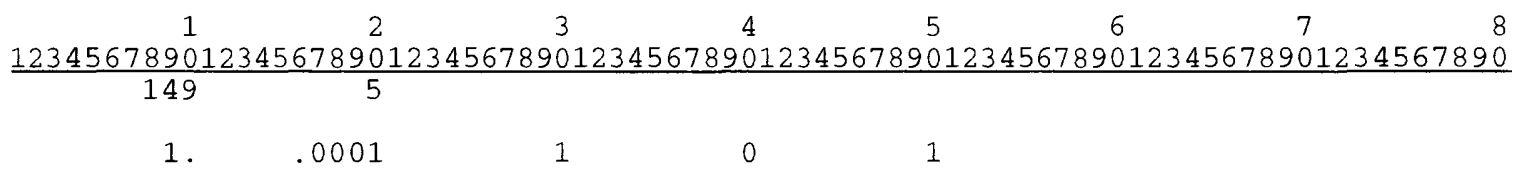

MODFLOW Output Control Option file, example1.oc:

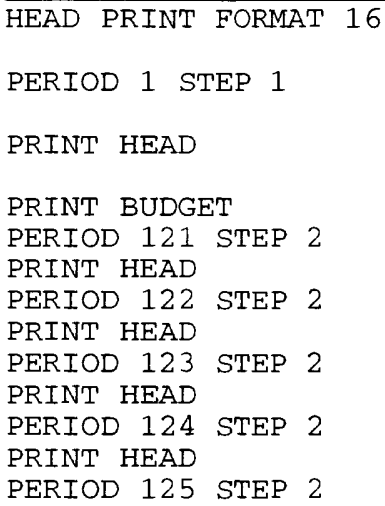


PRINT HEAD

PERIOD 126 STEP 2

PRINT HEAD

PERIOD 127 STEP 2

PRINT HEAD

PERIOD 128 STEP 2

PRINT HEAD

PERIOD 129 STEP 2

PRINT HEAD

PERIOD 130 STEP 2

PRINT HEAD

PERIOD 131 STEP 2

PRINT HEAD

PERIOD 132 STEP 2

PRINT HEAD

PERIOD 133 STEP 2

PRINT HEAD

PERIOD 134 STEP 2

PRINT HEAD

PERIOD 135 STEP 2

PRINT HEAD

PERIOD 136 STEP 2

PRINT HEAD

PERIOD 137 STEP 2

PRINT HEAD

PERIOD 138 STEP 2

PRINT HEAD

PERIOD 139 STEP 2

PRINT HEAD

PERIOD 140 STEP 2

PRINT HEAD 


\title{
APPENDIX C. MODFLOW DATA FILES FOR EXAMPLE 2 SIMULATION
}

MODFLOW name file for Example 2 simulation:

\author{
$\begin{array}{llllllll}1 & 2 & 3 & 4 & 5 & 6 & 7 & 8\end{array}$ \\ 12345678901234567890123456789012345678901234567890123456789012345678901234567890 \\ LIST 8 example2.1st \\ BAS 7 example2.bas \\ 11 example2.bcf \\ OC 22 example2.OC \\ SIP 23 example2.sip \\ DAF 28 example2.inf \\ DAFG 29 example2. ing \\ DAFF 30 bltm. flw
}

MODFLOW Basic Package file, example2.bas:

$\begin{array}{lllllllll}1 & 2 & 3 & 4 & 5 & 6 & 7\end{array}$ 12345678901234567890123456789012345678901234567890123456789012345678901234567890 OFR 88-729 Test Problem 2

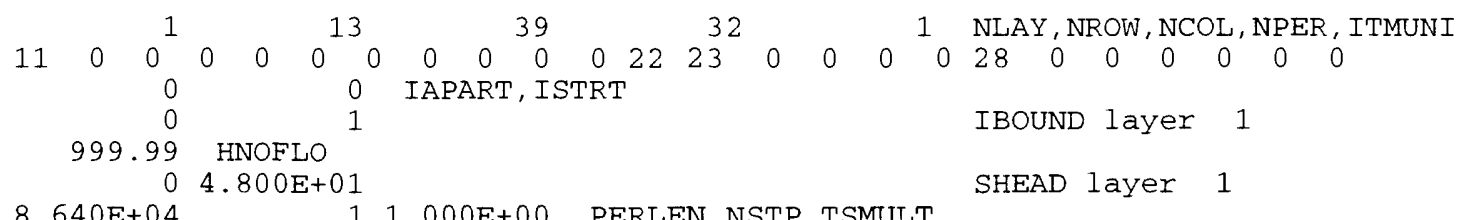
8. $640 \mathrm{E}+04$
$11.000 \mathrm{E}+00$
1 1. $1.000 \mathrm{E}+00$
$11.000 \mathrm{E}+00$
8. $640 \mathrm{E}+04$
$11.000 \mathrm{E}+00$
$11.000 \mathrm{E}+00$
8. $640 \mathrm{E}+04$
1 1. $000 \mathrm{E}+00$
8. $640 \mathrm{E}+04$
$11.000 \mathrm{E}+00$
8. $640 \mathrm{E}+04$
$11.000 \mathrm{E}+00$
8. $640 \mathrm{E}+04$
$11.000 E+00$
8. $640 \mathrm{E}+04$
$11.000 E+00$
$8.640 \mathrm{E}+04$
$11.000 \mathrm{E}+00$
8. $640 \mathrm{E}+04$
$11.000 \mathrm{E}+00$
$8.640 \mathrm{E}+04$
$11.000 \mathrm{E}+00$
8. $640 \mathrm{E}+04$
$11.000 \mathrm{E}+00$
8. $640 \mathrm{E}+04$
$11.000 E+00$
8. $640 \mathrm{E}+04$
$11.000 \mathrm{E}+00$
8. $640 \mathrm{E}+04$
$11.000 \mathrm{E}+00$
$11.000 \mathrm{E}+00$
8. $640 \mathrm{E}+04$
PERLEN, NSTP, TSMULT
PERLEN, NSTP, TSMULT
PERLEN, NSTP, TSMULT
PERLEN, NSTP, TSMULT
PERLEN, NSTP, TSMULT
PERLEN, NSTP, TSMULT
PERLEN, NSTP, TSMULT
PERLEN, NSTP, TSMULT
PERLEN, NSTP, TSMULT
PERLEN, NSTP, TSMULT
PERLEN, NSTP, TSMULT
PERLEN, NSTP, TSMULT
PERLEN, NSTP, TSMULT
PERLEN, NSTP, TSMULT
PERLEN, NSTP, TSMULT
PERLEN, NSTP, TSMULT
PERLEN, NSTP, TSMULT
PERLEN, NSTP, TSMULT
$11.000 \mathrm{E}+00$
$11.000 \mathrm{E}+00$
PERLEN, NSTP, TSMULT
PERLEN, NSTP, TSMULT
$8.640 \mathrm{E}+04$
$11.000 \mathrm{E}+00$
$11.000 \mathrm{E}+00$
$11.000 \mathrm{E}+00$
$11.000 \mathrm{E}+00$
PERLEN , NSTP , TSMULT
8. $640 \mathrm{E}+04$
PERLEN , NSTP, TSMULT
8. $640 \mathrm{E}+04$
PERLEN, NSTP, TSMULT
$11.000 E+00$ PERLEN, NSTP, TSMULT
$11.000 E+00$ PERLEN, NSTP, TSMULT
8. $640 \mathrm{E}+04$
$11.000 \mathrm{E}+00$
$8.640 \mathrm{E}+04$
$11.000 \mathrm{E}+00$
$11.000 \mathrm{E}+00$
PERLEN, NSTP, TSMULT
8. $640 \mathrm{E}+04$
$11.000 \mathrm{E}+00$
$8.640 \mathrm{E}+04$
$151.000 \mathrm{E}+00$
PERLEN, NSTP , TSMULT
PERLEN, NSTP, TSMULT
PERLEN, NSTP, TSMULT
$1.296 \mathrm{E}+06$
$91.000 \mathrm{E}+00$
PERLEN, NSTP, TSMULT 
MODFLOW Block-Centered Flow Package file, example2.bcf:

\begin{tabular}{|c|c|c|c|c|c|c|c|}
\hline 13 & $\begin{array}{r}2 \\
390\end{array}$ & 3 & $\begin{array}{r}4 \\
890\end{array}$ & 5 & 6 & 7 & \\
\hline 0 & 0 & $1.00 \mathrm{E}+30$ & 0 & $5.00 E-01$ & 1 & 0 & \\
\hline \multicolumn{8}{|c|}{ 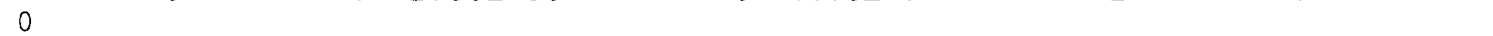 } \\
\hline 0 & $1.000 \mathrm{E}+00$ & & & & TRPY & & \\
\hline 11 & $1.000 \mathrm{E}+00$ & & $(8 \mathrm{~F} 10.0)$ & 0 & DELR & & \\
\hline $3.000 E+02$ & $2.000 E+02$ & $2.000 E+02$ & $2.000 E+02$ & $2.000 E+02$ & $2.000 E+02$ & $2.000 \mathrm{E}+02$ & $2.000 E+02$ \\
\hline $0 E+02$ & $2.000 E+02$ & $2.000 E+02$ & $2.000 \mathrm{E}+02$ & $2.000 \mathrm{E}+02$ & $2.000 E+02$ & $2.000 E+02$ & +02 \\
\hline $2.000 E+02$ & $2.000 E+02$ & $2.000 E+02$ & $2.000 E+02$ & $2.000 E+02$ & $2.000 E+02$ & $2.000 E+02$ & +02 \\
\hline $2.000 \mathrm{E}+02$ & $2.000 \mathrm{E}+02$ & $2.000 E+02$ & $2.000 E+02$ & $2.000 \mathrm{E}+02$ & $2.000 \mathrm{E}+02$ & $2.000 \mathrm{E}+02$ & $2.000 \mathrm{E}+02$ \\
\hline $00 E+02$ & $2.000 E+02$ & $2.000 E+02$ & $2.000 E+02$ & $2.000 \mathrm{E}+02$ & $2.000 E+02$ & $3.000 \mathrm{E}+02$ & \\
\hline 0 & $1.000 E+03$ & & & & DELC & & \\
\hline 0 & $2.000 \mathrm{E}-01$ & & & & SF1 laye & & \\
\hline 0 & $3.700 \mathrm{E}-02$ & & & & TRAN lay & er & \\
\hline
\end{tabular}

MODFLOW Output Control Option file, example2.oc:

$\frac{12345678901234567890123456789012345678901234567890123456789012345678901234567890}{8}$

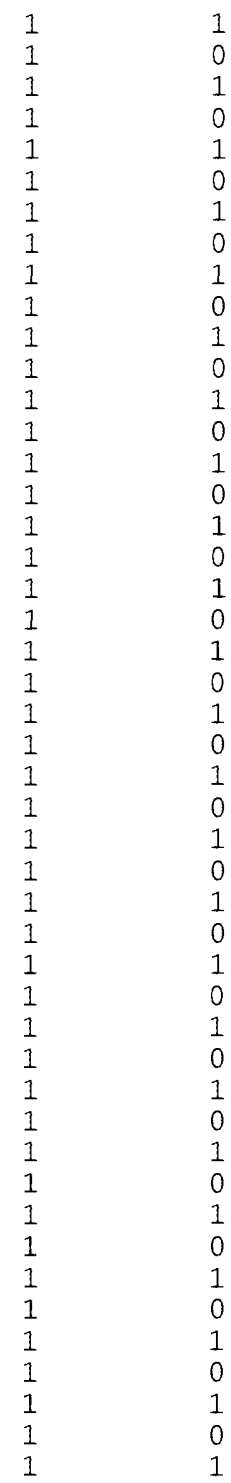

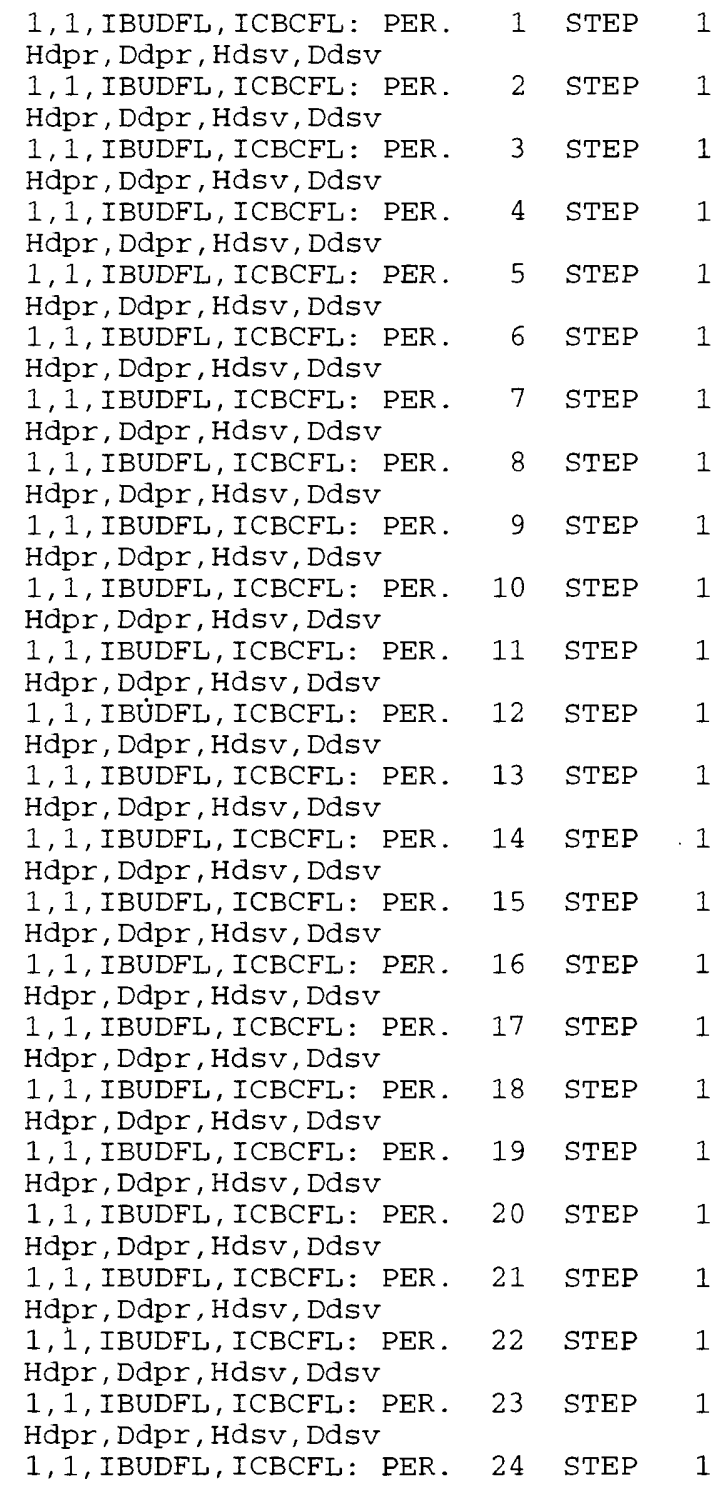




\section{MODFLOW Strongly-Implicit Procedure Package file, example2.sip:}

$\frac{1}{12345678901234567890123456789012345678901234567890123456789012345678901234567890}$

1. .00001

1

0

1 


\section{APPENDIX D. MODFLOW DATA FILES FOR EXAMPLE 3 SIMULATION}

MODFLOW name file for Example 3 simulation:

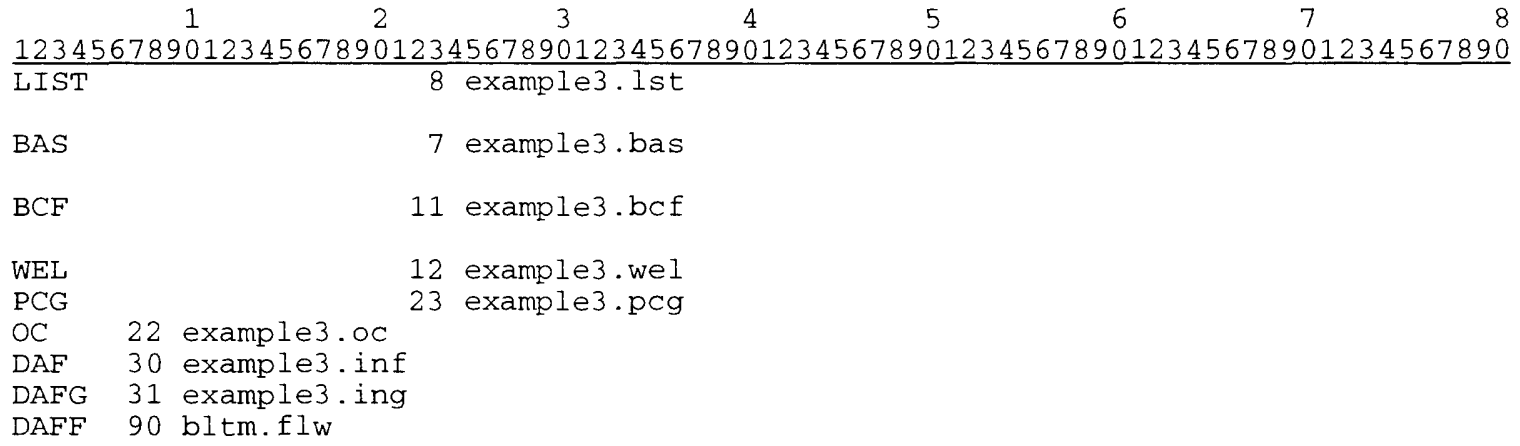

MODFLOW Basic Package file, example3.bas:

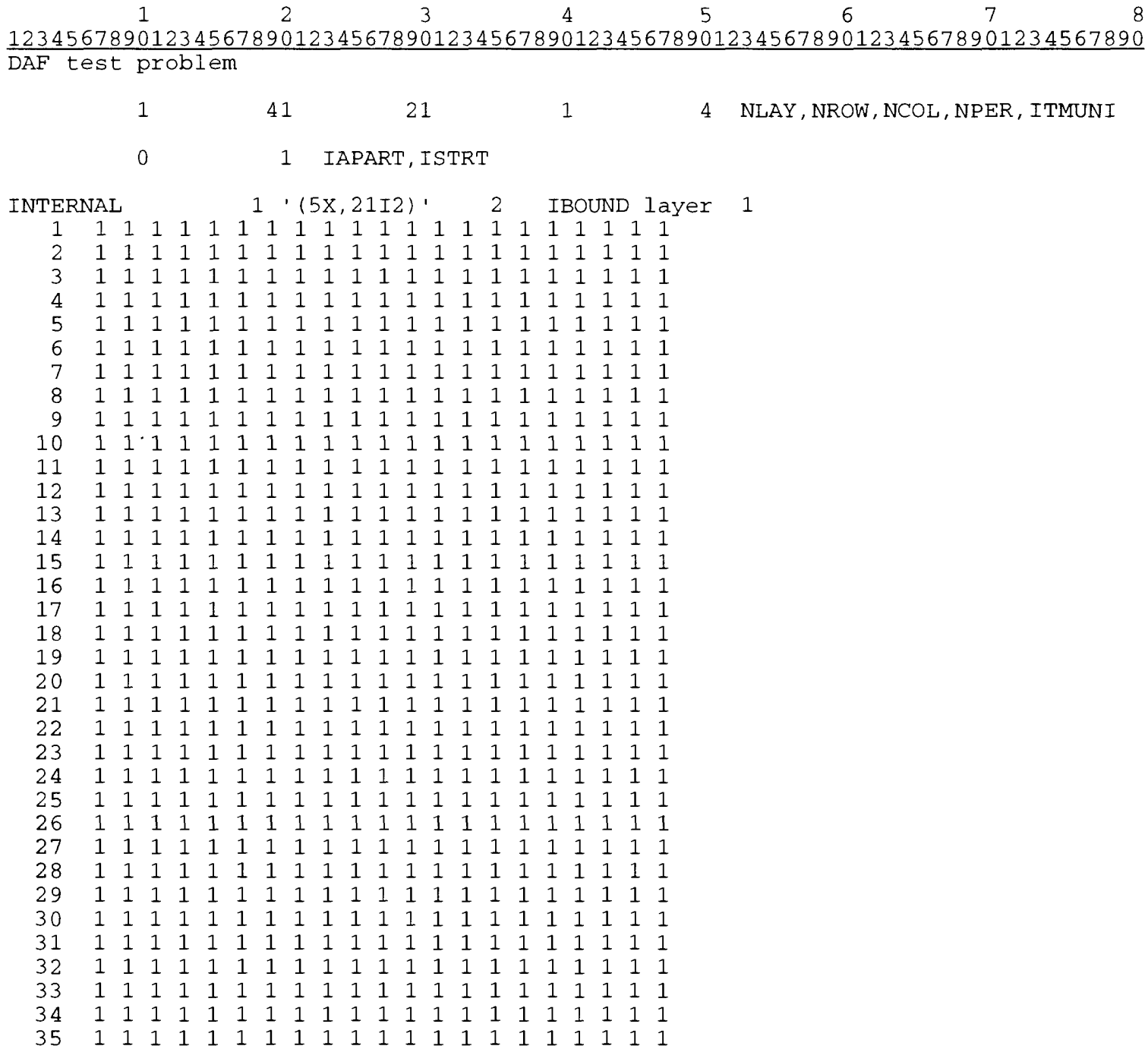




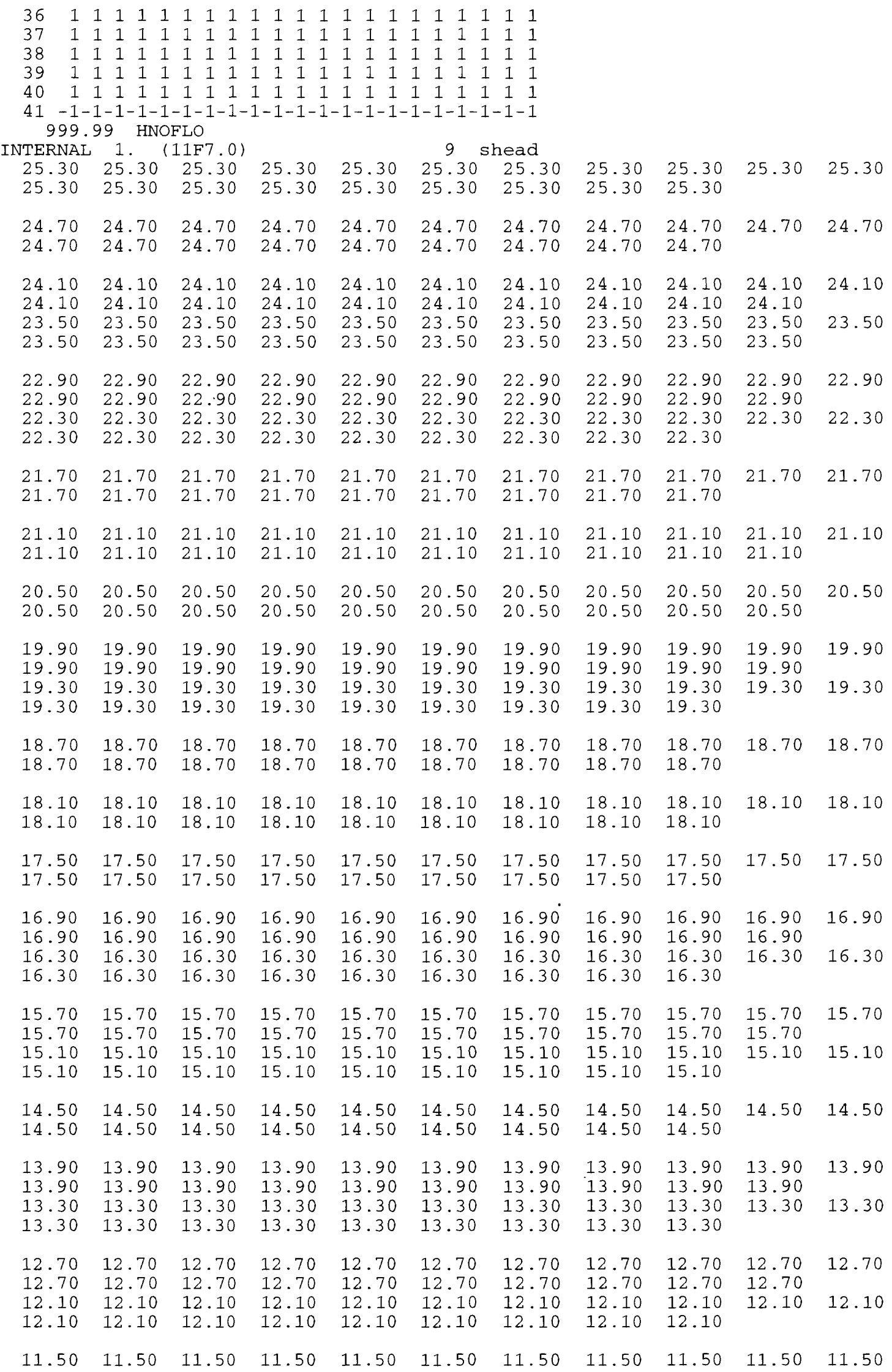




\begin{tabular}{|c|c|c|c|c|c|c|c|c|c|c|}
\hline 11.50 & 11.50 & 11.50 & 11.50 & 11.50 & 11.50 & 11.50 & 11.50 & 11.50 & & \\
\hline $\begin{array}{l}10.90 \\
10.90\end{array}$ & $\begin{array}{l}10.90 \\
10.90\end{array}$ & $\begin{array}{l}10.90 \\
10.90\end{array}$ & $\begin{array}{l}10.90 \\
10.90\end{array}$ & $\begin{array}{l}10.90 \\
10.90\end{array}$ & $\begin{array}{l}10.90 \\
10.90\end{array}$ & $\begin{array}{l}10.90 \\
10.90\end{array}$ & $\begin{array}{l}10.90 \\
10.90\end{array}$ & $\begin{array}{l}10.90 \\
10.90\end{array}$ & 10.90 & 10.90 \\
\hline $\begin{array}{l}10.30 \\
10.30\end{array}$ & $\begin{array}{l}10.30 \\
10.30\end{array}$ & $\begin{array}{l}10.30 \\
10.30\end{array}$ & $\begin{array}{l}10.30 \\
10.30\end{array}$ & $\begin{array}{l}10.30 \\
10.30\end{array}$ & $\begin{array}{l}10.30 \\
10.30\end{array}$ & $\begin{array}{l}10.30 \\
10.30\end{array}$ & $\begin{array}{l}10 \cdot 30 \\
10.30\end{array}$ & $\begin{array}{l}10.30 \\
10.30\end{array}$ & 10.30 & 10.30 \\
\hline $\begin{array}{l}9.700 \\
9.700 \\
9.100 \\
9.100\end{array}$ & $\begin{array}{l}9.700 \\
9.700 \\
9.100 \\
9.100\end{array}$ & $\begin{array}{l}9.700 \\
9.700 \\
9.100 \\
9.100\end{array}$ & $\begin{array}{l}9.700 \\
9.700 \\
9.100 \\
9.100\end{array}$ & $\begin{array}{l}9.700 \\
9.700 \\
9.100 \\
9.100\end{array}$ & $\begin{array}{l}9.700 \\
9.700 \\
9.100 \\
9.100\end{array}$ & $\begin{array}{l}9.700 \\
9.700 \\
9.100 \\
9.100\end{array}$ & $\begin{array}{l}9.700 \\
9.700 \\
9.100 \\
9.100\end{array}$ & $\begin{array}{l}9.700 \\
9.700 \\
9.100 \\
9.100\end{array}$ & $\begin{array}{l}9.700 \\
9.700 \\
9.100\end{array}$ & 9.700 \\
\hline $\begin{array}{l}8.500 \\
8.500 \\
7.900 \\
7.900\end{array}$ & $\begin{array}{l}8.500 \\
8.500 \\
7.900 \\
7.900\end{array}$ & $\begin{array}{l}8.500 \\
8.500 \\
7.900 \\
7.900\end{array}$ & $\begin{array}{l}8.500 \\
8.500 \\
7.900 \\
7.900\end{array}$ & $\begin{array}{l}8.500 \\
8.500 \\
7.900 \\
7.900\end{array}$ & $\begin{array}{l}8.500 \\
8.500 \\
7.900 \\
7.900\end{array}$ & $\begin{array}{l}8.500 \\
8.500 \\
7.900 \\
7.900\end{array}$ & $\begin{array}{l}8.500 \\
8.500 \\
7.900 \\
7.900\end{array}$ & $\begin{array}{l}8.500 \\
8.500 \\
7.900 \\
7.900\end{array}$ & $\begin{array}{l}8.500 \\
8.500 \\
7.900\end{array}$ & 7.900 \\
\hline $\begin{array}{l}7.300 \\
7.300\end{array}$ & $\begin{array}{l}7.300 \\
7.300\end{array}$ & $\begin{array}{l}7.300 \\
7.300\end{array}$ & $\begin{array}{l}7.300 \\
7.300\end{array}$ & $\begin{array}{l}7.300 \\
7.300\end{array}$ & $\begin{array}{l}7.300 \\
7.300\end{array}$ & $\begin{array}{l}7.300 \\
7.300\end{array}$ & $\begin{array}{l}7.300 \\
7.300\end{array}$ & $\begin{array}{l}7.300 \\
7.300\end{array}$ & 7.300 & 7.300 \\
\hline $\begin{array}{l}6.700 \\
6.700 \\
6.100 \\
6.100\end{array}$ & $\begin{array}{l}6.700 \\
6.700 \\
6.100 \\
6.100\end{array}$ & $\begin{array}{l}6.700 \\
6.700 \\
6.100 \\
6.100\end{array}$ & $\begin{array}{l}6.700 \\
6.700 \\
6.100 \\
6.100\end{array}$ & $\begin{array}{l}6.700 \\
6.700 \\
6.100 \\
6.100\end{array}$ & $\begin{array}{l}6.700 \\
6.700 \\
6.100 \\
6.100\end{array}$ & $\begin{array}{l}6.700 \\
6.700 \\
6.100 \\
6.100\end{array}$ & $\begin{array}{l}6.700 \\
6.700 \\
6.100 \\
6.100\end{array}$ & $\begin{array}{l}6.700 \\
6.700 \\
6.100 \\
6.100\end{array}$ & $\begin{array}{l}6.700 \\
6.700 \\
6.100\end{array}$ & $\begin{array}{l}6.700 \\
6.100\end{array}$ \\
\hline $\begin{array}{l}5.500 \\
5.500 \\
4.900 \\
4.900\end{array}$ & $\begin{array}{l}5.500 \\
5.500 \\
4.900 \\
4.900\end{array}$ & $\begin{array}{l}5.500 \\
5.500 \\
4.900 \\
4.900\end{array}$ & $\begin{array}{l}5.500 \\
5.500 \\
4.900 \\
4.900\end{array}$ & $\begin{array}{l}5.500 \\
5.500 \\
4.900 \\
4.900\end{array}$ & $\begin{array}{l}5.500 \\
5.500 \\
4.900 \\
4.900\end{array}$ & $\begin{array}{l}5.500 \\
5.500 \\
4.900 \\
4.900\end{array}$ & $\begin{array}{l}5.500 \\
5.500 \\
4.900 \\
4.900\end{array}$ & $\begin{array}{l}5.500 \\
5.500 \\
4.900 \\
4.900\end{array}$ & $\begin{array}{l}5.500 \\
5.500 \\
4.900\end{array}$ & $\begin{array}{l}5.500 \\
4.900\end{array}$ \\
\hline $\begin{array}{l}4.300 \\
4.300\end{array}$ & $\begin{array}{l}4.300 \\
4.300\end{array}$ & $\begin{array}{l}4.300 \\
4.300\end{array}$ & $\begin{array}{l}4.300 \\
4.300\end{array}$ & $\begin{array}{l}4.300 \\
4.300\end{array}$ & $\begin{array}{l}4.300 \\
4.300\end{array}$ & $\begin{array}{l}4.300 \\
4.300\end{array}$ & $\begin{array}{l}4.300 \\
4.300\end{array}$ & $\begin{array}{l}4.300 \\
4.300\end{array}$ & 4.300 & 4.300 \\
\hline $\begin{array}{l}3.700 \\
3.700\end{array}$ & $\begin{array}{l}3.700 \\
3.700\end{array}$ & $\begin{array}{l}3.700 \\
3.700\end{array}$ & $\begin{array}{l}3.700 \\
3.700\end{array}$ & $\begin{array}{l}3.700 \\
3.700\end{array}$ & $\begin{array}{l}3.700 \\
3.700\end{array}$ & $\begin{array}{l}3.700 \\
3.700\end{array}$ & $\begin{array}{l}3.700 \\
3.700\end{array}$ & $\begin{array}{l}3.700 \\
3.700\end{array}$ & $\begin{array}{l}3.700 \\
3.700\end{array}$ & 3.700 \\
\hline $\begin{array}{l}3.100 \\
3.100\end{array}$ & $\begin{array}{l}3.100 \\
3.100\end{array}$ & $\begin{array}{l}3.100 \\
3.100\end{array}$ & $\begin{array}{l}3.100 \\
3.100\end{array}$ & $\begin{array}{l}3.100 \\
3.100\end{array}$ & $\begin{array}{l}3.100 \\
3.100\end{array}$ & $\begin{array}{l}3.100 \\
3.100\end{array}$ & $\begin{array}{l}3.100 \\
3.100\end{array}$ & $\begin{array}{l}3.100 \\
3.100\end{array}$ & $\begin{array}{l}3.100 \\
3.100\end{array}$ & 3.100 \\
\hline $\begin{array}{l}2.500 \\
2.500 \\
1.900\end{array}$ & $\begin{array}{l}2.500 \\
2.500 \\
1.900\end{array}$ & $\begin{array}{l}2.500 \\
2.500 \\
1.900\end{array}$ & $\begin{array}{l}2.500 \\
2.500 \\
1.900\end{array}$ & $\begin{array}{l}2.500 \\
2.500 \\
1.900\end{array}$ & $\begin{array}{l}2.500 \\
2.500 \\
1.900\end{array}$ & $\begin{array}{l}2.500 \\
2.500 \\
1.900\end{array}$ & $\begin{array}{l}2.500 \\
2.500 \\
1.900\end{array}$ & $\begin{array}{l}2.500 \\
2.500 \\
1.900\end{array}$ & $\begin{array}{l}2.500 \\
2.500 \\
1.900\end{array}$ & $\begin{array}{l}2.500 \\
1.900\end{array}$ \\
\hline $\begin{array}{l}.300 \\
.300\end{array}$ & $\begin{array}{l}1.300 \\
1.300\end{array}$ & $\begin{array}{l}1.300 \\
1.300\end{array}$ & $\begin{array}{l}1.300 \\
1.300\end{array}$ & $\begin{array}{l}1.300 \\
1.300\end{array}$ & $\begin{array}{l}1.300 \\
1.300\end{array}$ & $\begin{array}{l}1.300 \\
1.300\end{array}$ & $\begin{array}{l}1.300 \\
1.300\end{array}$ & $\begin{array}{l}1.300 \\
1.300\end{array}$ & $\begin{array}{l}1.300 \\
1.300\end{array}$ & 1.300 \\
\hline
\end{tabular}

$.66666667 \quad 321.000 E+00 \quad$ PERLEN, NSTP, TSMULT

\section{MODFLOW Block-Centered Flow Package file, example3.bcf:}

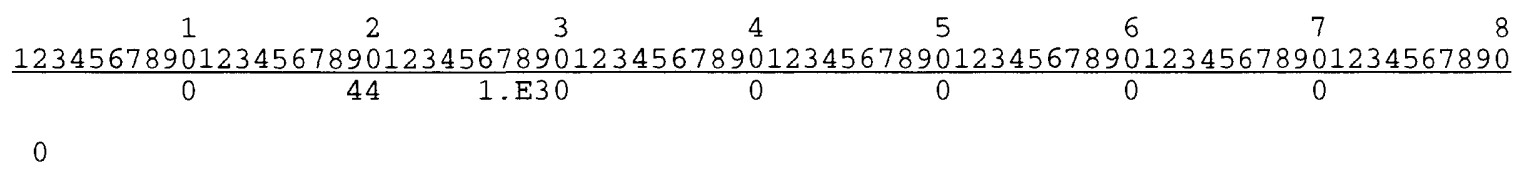

\footnotetext{
CONSTANT 1.

CONSTANT 500 .

CONSTANT 500 .

CONSTANT $.20 \quad$ Storage coefficient

CONSTANT 10000. Transmissivity
} 
MODFLOW Well Package file, example3.wel:

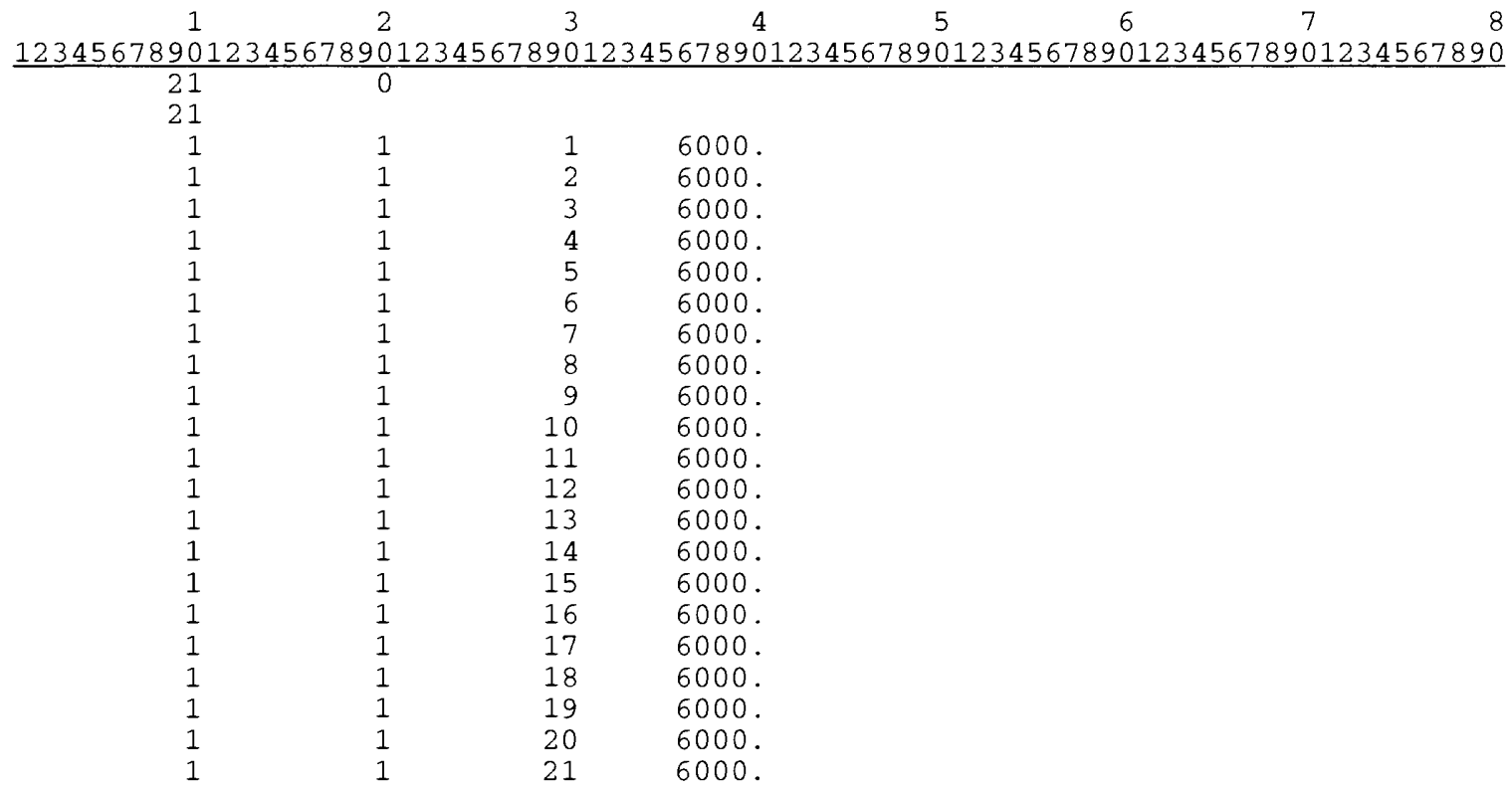

MODFLOW Preconditioned Conjugant-Gradient Package file, example3.pcg:

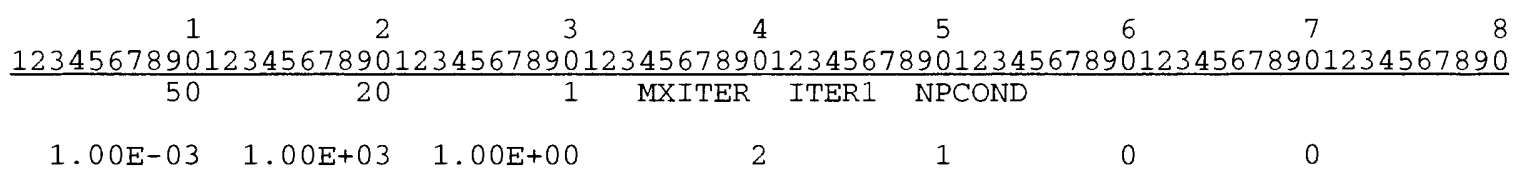


MODFLOW Output Control Option file, example3.oc:

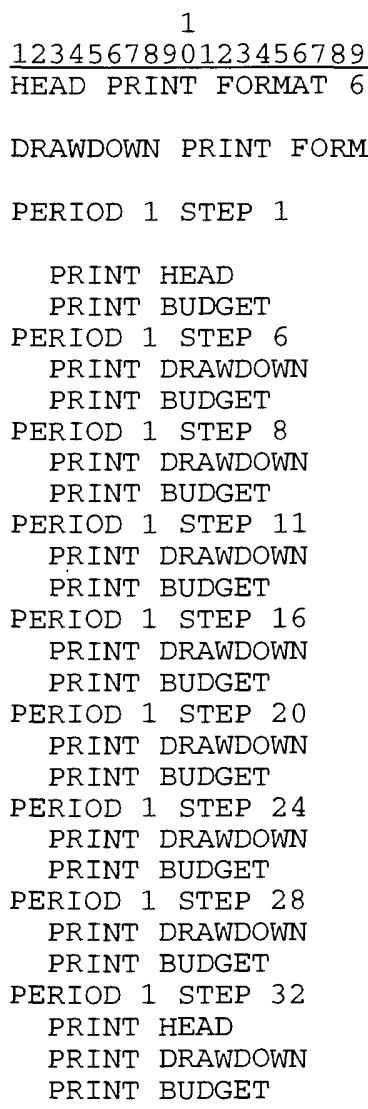

